I N T ER N ATIONAL MONETARY FUND

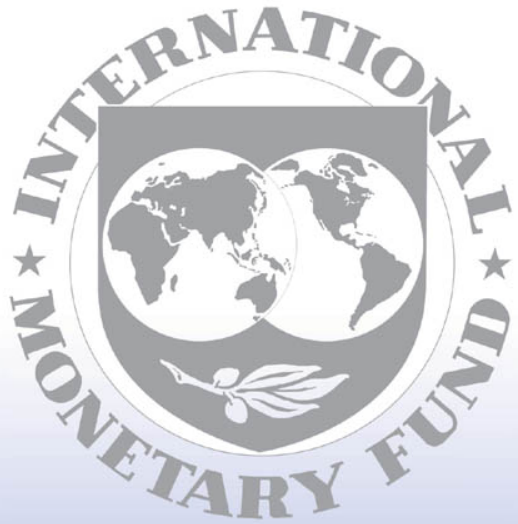

Staff

Country

Reports 


\title{
Ukraine: 2006 Article IV Consultation-Staff Report; Staff Statement; and Public Information Notice on the Executive Board Discussion
}

Under Article IV of the IMF's Articles of Agreement, the IMF holds bilateral discussions with members, usually every year. In the context of the 2006 Article IV consultation with Ukraine, the following documents have been released and are included in this package:

- $\quad$ the staff report for the 2006 Article IV consultation, prepared by a staff team of the IMF, following discussions that ended on October 25, 2006, with the officials of Ukraine on economic developments and policies. Based on information available at the time of these discussions, the staff report was completed on December 21, 2006. The views expressed in the staff report are those of the staff team and do not necessarily reflect the views of the Executive Board of the IMF;

- a staff statement of January 12, 2007 updating information on recent developments; and

- $\quad$ a Public Information Notice (PIN) summarizing the views of the Executive Board as expressed during its January 12, 2007 discussion of the staff report that concluded the Article IV consultation.

The document listed below have been or will be separately released.

Selected Issues

Statistical Appendix

The policy of publication of staff reports and other documents allows for the deletion of market-sensitive information.

To assist the IMF in evaluating the publication policy, reader comments are invited and may be sent by e-mail to publicationpolicy@imf.org.

Copies of this report are available to the public from

International Monetary Fund • Publication Services

$70019^{\text {th }}$ Street, N.W. • Washington, D.C. 20431

Telephone: (202) 623-7430 • Telefax: (202) 623-7201

E-mail: publications@imf.org •Internet: http://www.imf.org

Price: $\$ 18.00$ a copy

\author{
International Monetary Fund \\ Washington, D.C.
}


This page intentionally left blank 


\section{INTERNATIONAL MONETARY FUND}

\section{UKRAINE \\ Staff Report for the 2006 Article IV Consultation}

Prepared by the Staff Representatives for the 2006 Consultation with Ukraine

Approved by Juha Kähkönen and Michael T. Hadjimichael

December 20, 2006

- Date and place: October 12-25, 2006, in Kyiv. The concluding statement of the mission was posted at www.imf.org on November 30, 2006.

- $\quad$ Country interlocutors: First Deputy Prime Minister and Finance Minister Azarov, Economy Minister Makukha, NBU Governor Stelmakh, other senior officials, representatives of parliament, the diplomatic community, the financial sector, and think tanks. Mr. Yakusha (OED) attended the discussions.

- IMF team: Messrs. Jaeger (head), Flanagan, Chelsky, Ms. Schaechter (all EUR), Ms. Gonzalez (FAD), Mr. Halikias (PDR), Ms. Ribakova (MCM), and Mr. Franks, Senior Resident Representative.

- Political developments: Following parliamentary elections in March 2006, a three-party coalition government, led by Prime Minister Yanukovich, took office in August 2006.

- Background studies: A separately published Selected Issues paper provides background on three topics: (1) Macroeconomic and Fiscal Effects of Energy Price Shocks; (2) Monetary and Exchange Rate Policy Framework; and (3) Dollarization and Banks' Foreign Exchange Risks.

- $\quad$ Fund relations: The previous consultation was concluded on

November 9, 2005. The conclusions of the Executive Board's discussions and country documents were made available at www.imf.org on November 28, 2005. Ukraine has accepted the obligations of Article VIII, Sections 2, 3, and 4, and maintains an exchange rate system free of restrictions on the making of payments and transfers for current international transactions.

- Data: Ukraine subscribed to the Fund's Special Data Dissemination Standard (SDDS) in 2003, and its data provision to the Fund is broadly adequate for surveillance, albeit with several shortcomings (Appendix V). 
Glossary ...1.

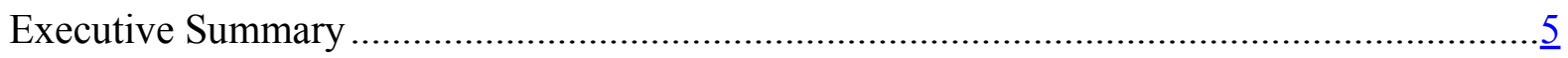

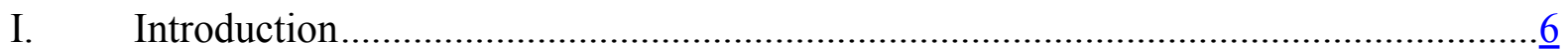

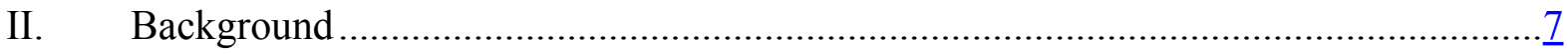

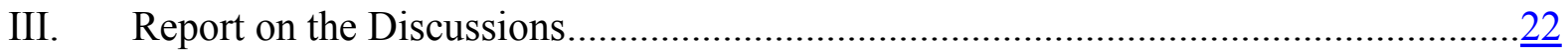

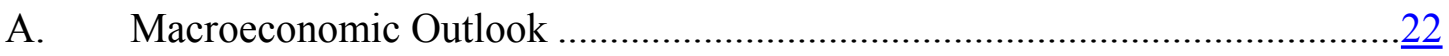

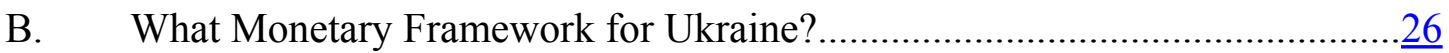

C. What Should be Done to Contain Banking-Sector Vulnerabilities? .................28

D. Is Ukraine's Fiscal Framework Adequate? ..................................................29

E. How Can Ukraine Catch Up with its More Advanced Transition Peers?..........31

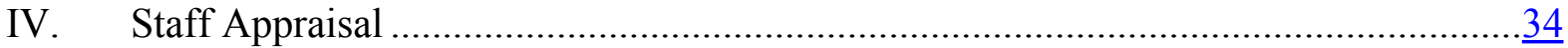

Text Boxes

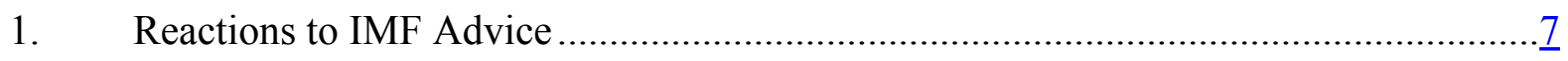

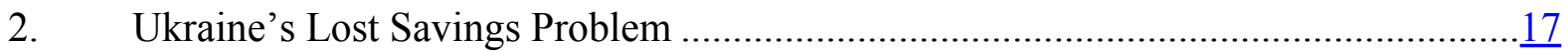

3. Foreign Currency-Induced Credit Risk: A Sensitivity Analysis.................................29

Figures

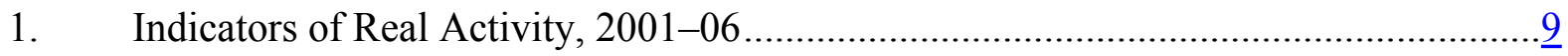

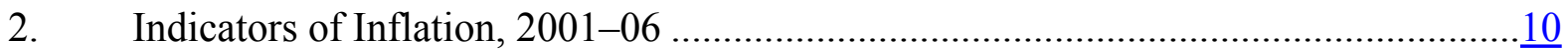

3. Terms-of-Trade and Energy Dependence Indicators ..............................................

4. Current and Capital Account Indicators, 2001-06 ……………...............................13

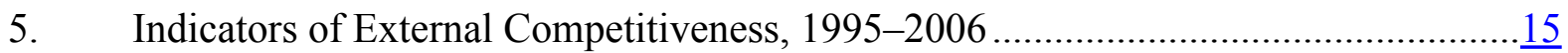

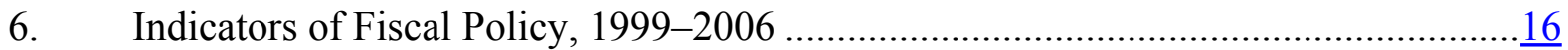

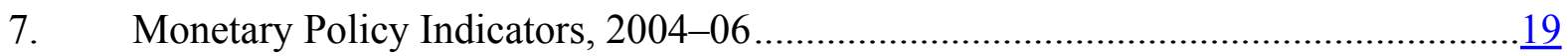

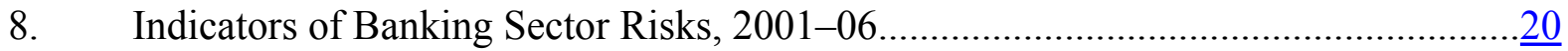

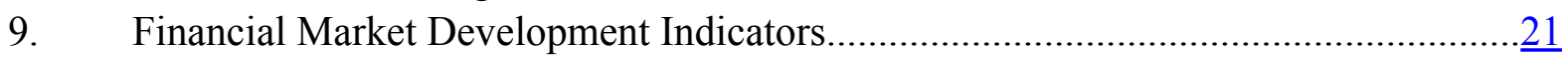

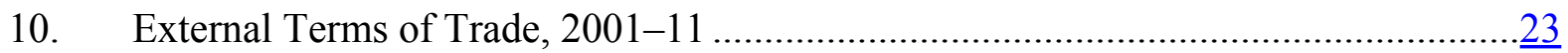

11. Macroeconomic Prospects Under Alternative Scenarios..........................................

12. Potential Output and Structural Reforms ..............................................................

Tables

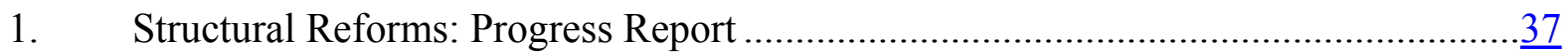

2. Selected Economic and Social Indicators, 2003-07 …………..............................

3. Medium-Term Balance of Payments, 2003-11 …………………….....................

4. Selected Vulnerability Indicators, 2002-06 …….............................................. 40

5. General Government Finances, 2004-07 ……….............................................

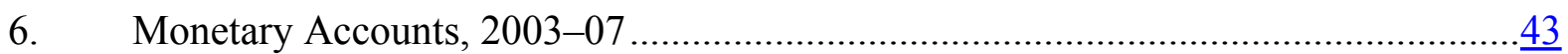

7. Financial Soundness Indicators for the Banking Sector, 2002-06 .............................44 
8. Medium-Term Macroeconomic Framework, Authorities' Policies........................... 45

9. Medium-Term Macroeconomic Framework, Recommended Policies ....................... $\underline{46}$

10. Moving to Inflation Targeting: Progress Report..................................................... 47

11. Millennium Development Goals .................................................................

\section{Appendices}

I. Debt Sustainability Analysis ...................................................................

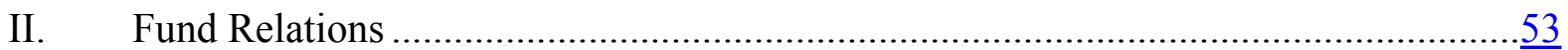

III. Relations with the World Bank ........................................................................ 57

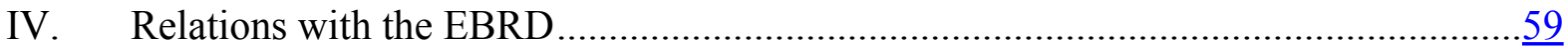

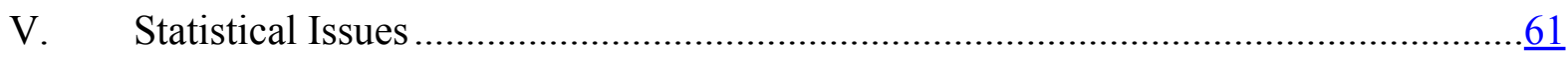




\section{GLOSSARY}

\begin{tabular}{|c|c|}
\hline AML & Anti-money laundering \\
\hline CAR & Capital-adequacy ratio \\
\hline CFT & Combating the financing of terrorism \\
\hline CIS & Commonwealth of Independent States \\
\hline CPI & Consumer price index \\
\hline DPL & Development Policy Loan \\
\hline EMBI & Emerging Market Bond Index \\
\hline EU & European Union \\
\hline EUR & IMF European Department \\
\hline FAD & IMF Fiscal Affairs Department \\
\hline FDI & Foreign direct investment \\
\hline FSAP & Financial Sector Assessment Program \\
\hline GIR & Gross international reserves \\
\hline IFS & International Financial Statistics \\
\hline LEG & IMF Legal Department \\
\hline MFD & IMF Monetary and Financial Systems Department \\
\hline $\mathrm{NBU}$ & National Bank of Ukraine \\
\hline NPLs & Nonperforming loans \\
\hline PDR & IMF Policy Development and Review Department \\
\hline PPI & Producer price index \\
\hline PPP & Purchasing power parity \\
\hline ROSC & Report on Standards and Codes \\
\hline SCS & State Committee on Statistics \\
\hline SDDS & Special Data Dissemination Standard \\
\hline SDR & Special Drawing Right \\
\hline SME & Small- and medium-sized enterprises \\
\hline SOE & State-owned enterprise \\
\hline SNA & System of National Accounts \\
\hline SRF & Standardized Report Forms \\
\hline STA & IMF Statistics Departments \\
\hline VAT & Value-added tax \\
\hline WTO & World Trade Organization \\
\hline
\end{tabular}




\section{EXECUTIVE SUMMARY}

Background. GDP growth is likely to rebound to 6 percent in 2006, helped by high steel export prices and strong domestic demand. The latter is underpinned by rapid income growth and reinforced by a credit boom. With domestic price pressures already significant, rising prices for energy imports have stoked CPI inflation, which will likely exceed 12 percent. Booming domestic demand, real currency appreciation, and rising energy prices are likely to shift the current account into a small deficit. Monetary policy has continued to be anchored by a de facto peg, while fiscal policy remained broadly neutral in 2006.

Outlook. Growth will likely slow to $4 \frac{1}{2}$ percent in 2007 , and the current-account deficit increase further to 4 percent of GDP, as import prices for natural gas continue to edge up. Inflation would likely drop to about 8 percent, given the authorities' intention not to continue pass-through of energy-price increases to consumers. The medium-term outlook is sensitive to external developments and policy responses. A benign external environment, featuring even higher steel prices and FDI, could produce growth in excess of 7 percent, but inflation could prove hard to control under a peg. Under an adverse external outlook, by contrast, the peg could lead to external sustainability problems.

Policy discussions. The discussions focused on the following issues:

- Monetary framework. The authorities foresee a very gradual transition to a more flexible exchange rate regime, reflecting their more sanguine view on the external outlook and concerns about the risks of abandoning the present de facto peg. Staff argued that the NBU should accelerate the transition. This would deliver better inflation control and help insulate the economy against adverse external developments.

- $\quad$ Coping with financial sector vulnerabilities. Authorities and staff agreed that Ukraine's long-standing credit boom and heavy external borrowing had raised vulnerabilities, particularly owing to foreign-exchange lending to unhedged borrowers. Staff urged a strengthening of the regulatory framework and a temporary increase in the capital-adequacy ratio.

- $\quad$ Fiscal framework. The authorities intended to target a fiscal deficit of about $2 \frac{1}{2}$ percent of GDP, while reducing both recurrent spending and taxes over the medium term. Staff viewed this as an appropriate framework, both from a debt sustainability and a policy-mix perspective, but specific policies planned for 2007 raise concerns, including a tilt toward expanding subsidies and tax preferences.

- $\quad$ Accelerating growth. The authorities saw spurring investment spending as key to boosting growth. Staff concurred but also noted that the really binding growth bottlenecks seemed to be insecure property rights, corruption, and a regulatory jungle - structural deficiencies that were also reflected in underdeveloped financial markets. 


\section{INTRODUCTION}

1. Since the last Article IV discussions, Ukraine's economy has proven surprisingly resilient. With growth having slowed sharply through 2005, the economy was hit by a 65 percent hike in the price of imported natural gas in early-2006. Political developments were also inauspicious: parliamentary elections in March 2006 triggered drawn-out political wrangling, and a new government took office only in August. In this setting, the authorities and IMF staff expected another year of below-potential economic performance. In the event, growth rebounded, spurred in part by resurging export prices for steel—Ukraine's main export-while CPI inflation moderated through most of 2006, helped by administrative delays in pass-through of higher energy prices.

2. Ukraine's macroeconomic challenges remain massive, however. Ukraine lags in its transition, and the new government's overarching objective is catching up with the income levels of its more advanced transition peers. At the same time, external risks to macroeconomic stability, particularly a sharp decline in the terms of trade, loom large. Further hikes in import prices for gas are in the offing, while export prices for steel could decline significantly from their present historical highs. As regards financial sector risks, a long-lasting domestic credit boom, increasingly in foreign currencies, and heavy external borrowing by the private sector have raised concerns about the banking sector's ability to cope with downside risks. Against this challenging backdrop, IMF staff and the authorities have continued to conduct a close policy dialogue (Box 1).

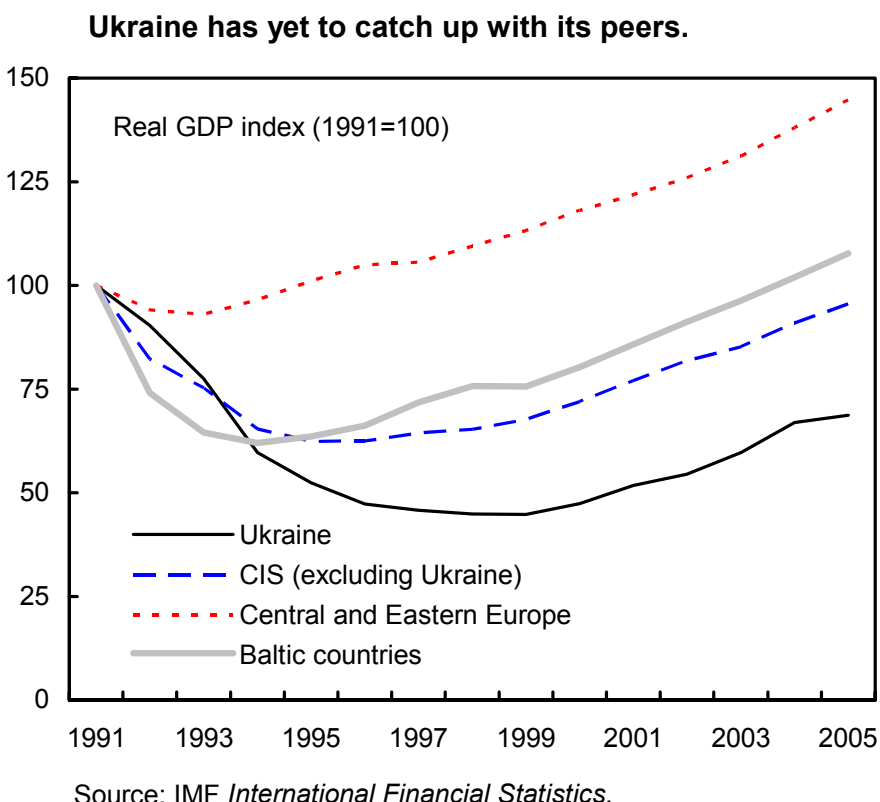




\section{Box 1. Reactions to IMF Advice}

While the authorities generally concur with IMF policy advice, implementation, particularly on structural issues, has been slow or uneven. This record may reflect an ingrained preference for gradualism but also a polarized body politic that has found it difficult to reach and sustain consensus on implementing market-friendly policies. ${ }^{1}$

Fiscal policy. In 2005, the authorities met the recommended cash deficit target of $2 \frac{1}{2}$ percent of GDP. For 2006, they targeted a higher deficit than recommended (31/4 versus $2 \frac{1}{4}$ percent of GDP), but may well undershoot their original target. At the same time, staff has been critical of the large increases in recurrent spending during 2005-06, mainly in public pensions and wages.

Monetary and exchange rate policy. While agreeing in principle with the staff's longstanding case for greater exchange rate flexibility, the NBU favors a very gradualist approach. But, IMF advice, particularly through technical assistance, has been instrumental in facilitating steps in liberalizing the foreign-exchange market and enhancing the NBU's policy-making capacity.

Financial sector. The NBU has been responsive to IMF advice. However, past staff proposals to hike the minimum capital-adequacy ratio from 10 to 12 percent have been rejected. Moreover, political consensus on various legal initiatives that would enhance transparency of banks' ownership structures and strengthen minority shareholder rights remains elusive.

Structural reforms. There were several recent advances in leveling the playing field for businesses and liberalizing foreign trade (see Table 1 for details). However, progress in other areas, including reforming the energy sector, tax administration, and public procurement, has stalled or even backtracked.

${ }^{1}$ Ukraine: Ex Post Assessment of Long-Term Use of Fund Resources (2005), available at www.imf.org, discusses the effectiveness of IMF policy advice over the last 15 years.

\section{BACKGROUND}

Recent growth and inflation developments have been better than expected.

3. After nose-diving in $\mathbf{2 0 0 5}$, real activity staged a surprise rebound in $\mathbf{2 0 0 6}$, with growth returning to par with regional peers. This volatility reflected several cross-currents (Figure 1): 
- Temporary impacts of post-

Output growth has been highly volatile.

Orange-Revolution policies.

Activity in trade and

construction in particular contracted sharply in 2005 , reflecting a clampdown on tax loopholes, smuggling, and corruption, as well as cutbacks in public-sector investment. Moreover, a re-privatization debate temporarily chilled investor sentiment, delaying some private investment into 2006.

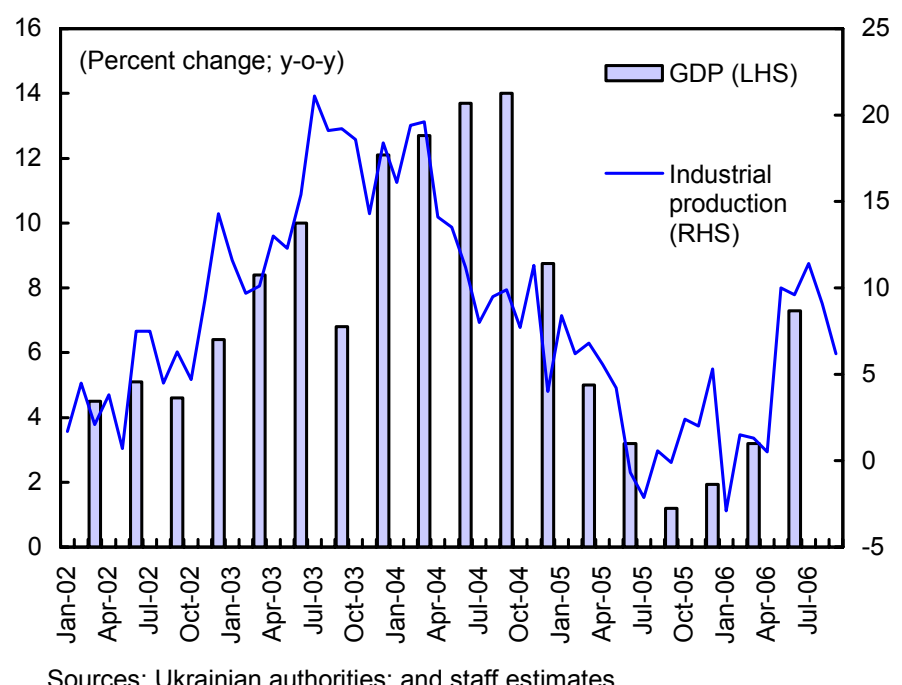

- $\quad$ Temporary export shocks. Export volumes slumped in 2005, reflecting a marked real currency appreciation, higher business-tax collections, and intensified thirdcountry competition in steel markets. However, pulled along by resurgent steel prices and robust trading-partner growth, exporters regained their footing in 2006.

- A fiscal-policy-driven consumption boom, reinforced by rapidly expanding household credit. While respecting low deficit targets, fiscal policy in 2005-06 reshuffled resources from higher-saving businesses (mainly by raising tax collections) to lower-saving households (mainly by raising public pensions and wages). Over the same time period, household credit expanded by well over 100 percent. As a result, private and public consumption have boomed, and the national savings rate is likely to have dropped by some 8 percent of GDP.

4. Inflation moderated through most of 2006, but has recently climbed back into double digits, boosted by energy-price pass-through. Monthly CPI headline inflation has swung widely over the last two years, even by regional standards (Figure 2). Notwithstanding booming consumption, high CPI inflation started to moderate in mid-2005. This reflected slowing real activity, low import price inflation, and a host of one-off factors, including temporary Russian import bans on Ukrainian meat and dairy products. However, as pass-through of

\begin{abstract}
After CPI inflation had come down in line with food price inflation, it has accelerated again.
\end{abstract}

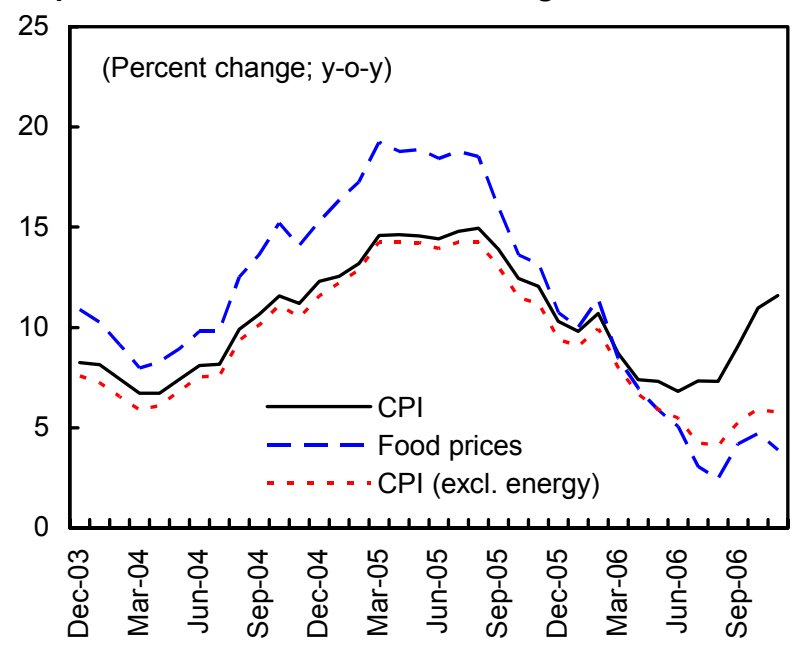

Sources: Ukrainian State Statistics Committee; and staff estimates. 
Figure 1. Ukraine: Indicators of Real Activity, 2001-06

After dropping sharply in 2005, Ukraine's real GDP growth is likely to have rebounded to the CIS average in 2006.

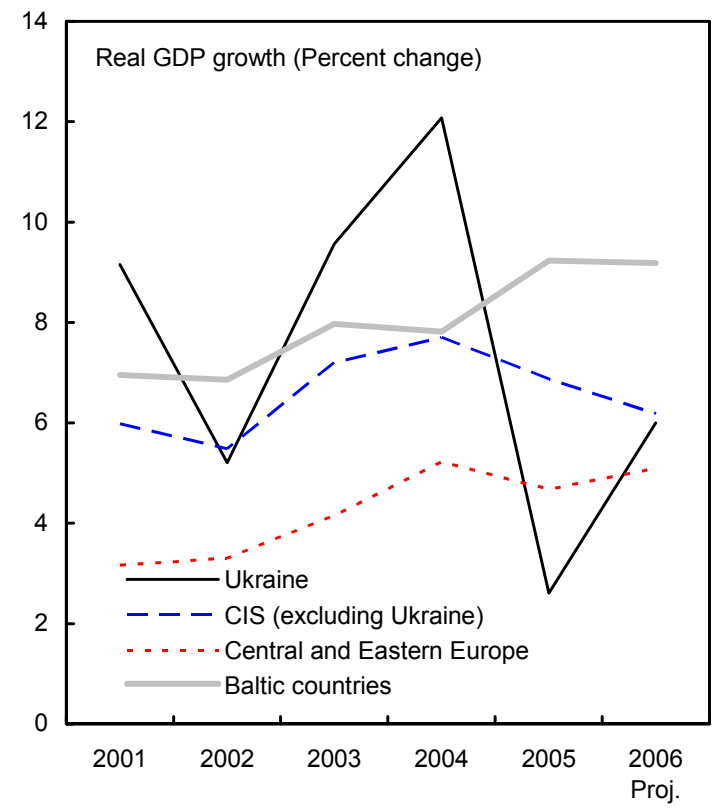

On the demand side, negative net exports slowed GDP growth in 2005-06, while domestic demand continued to boom.

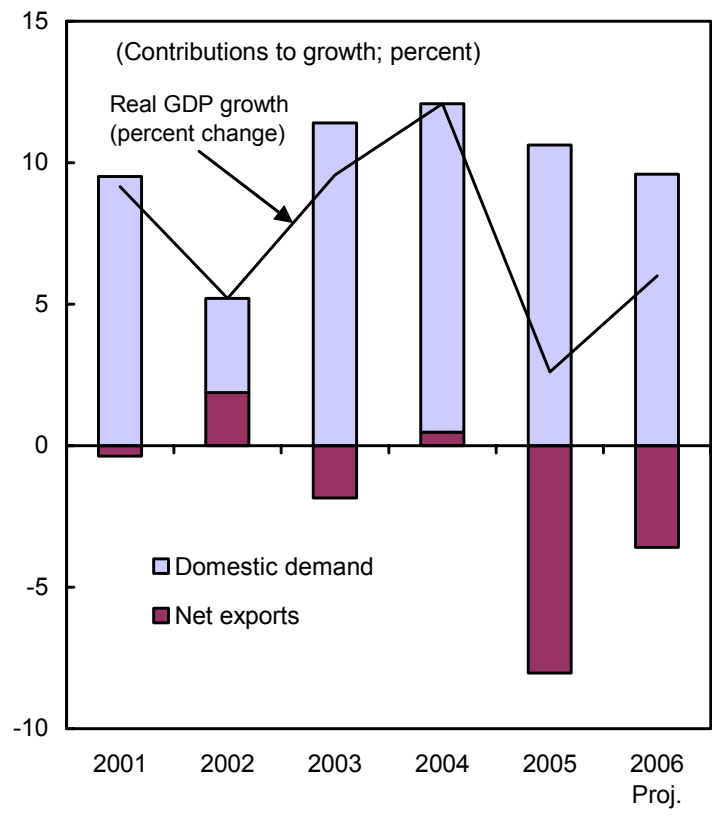

Real output volatility has been particularly pronounced in the trade and construction sectors.

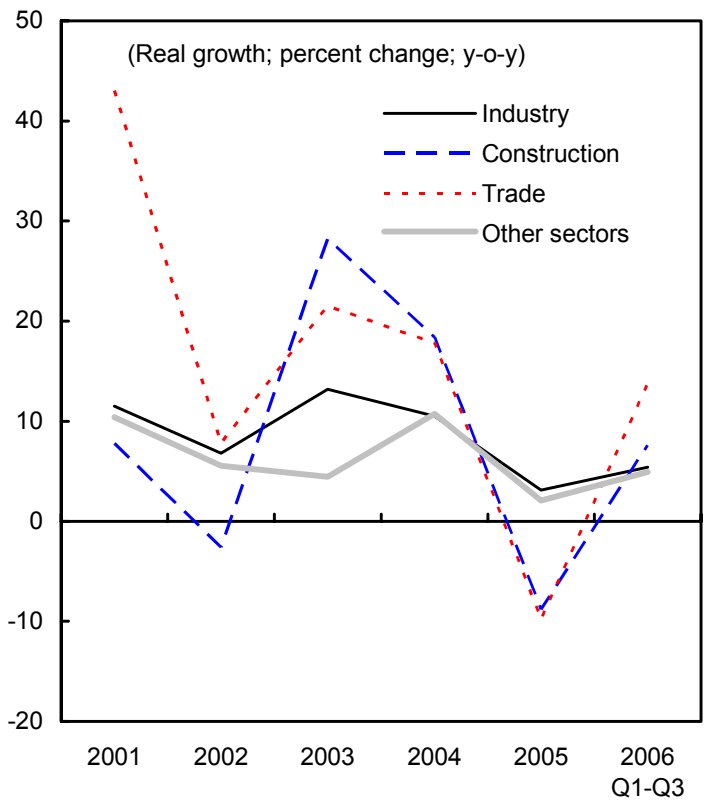

With consumption expanding at a particularly rapid clip, national savings have dropped sharply.

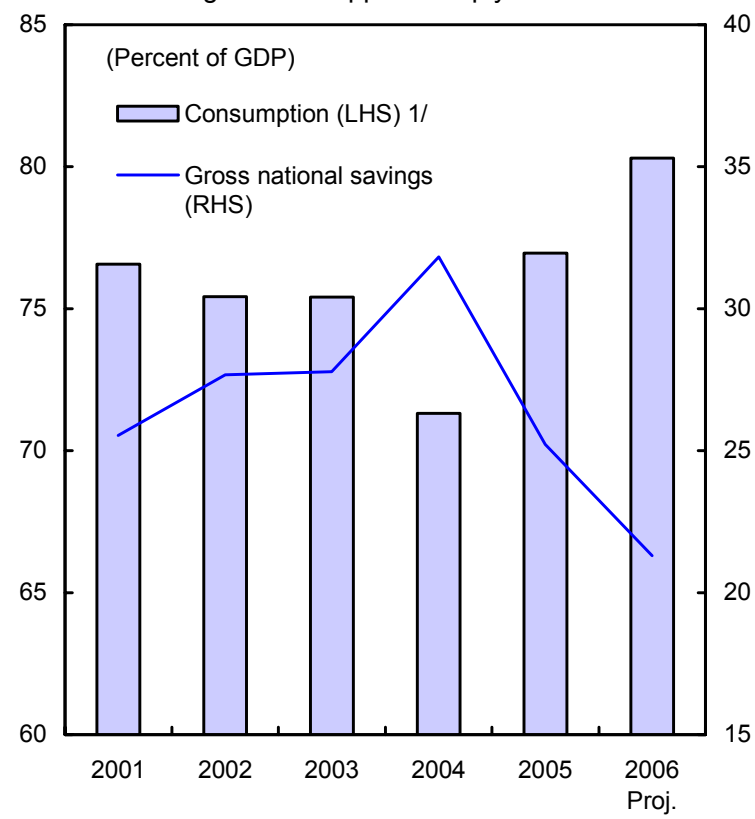

Sources: Ukrainian authorities; IMF International Financial Statistics; and staff estimates.

1/ Private and public consumption. 
Figure 2. Ukraine: Indicators of Inflation, 2001-06

Compared with other transition economies, Ukraine's recent $\mathrm{CPI}$ inflation rates have been high and volatile.

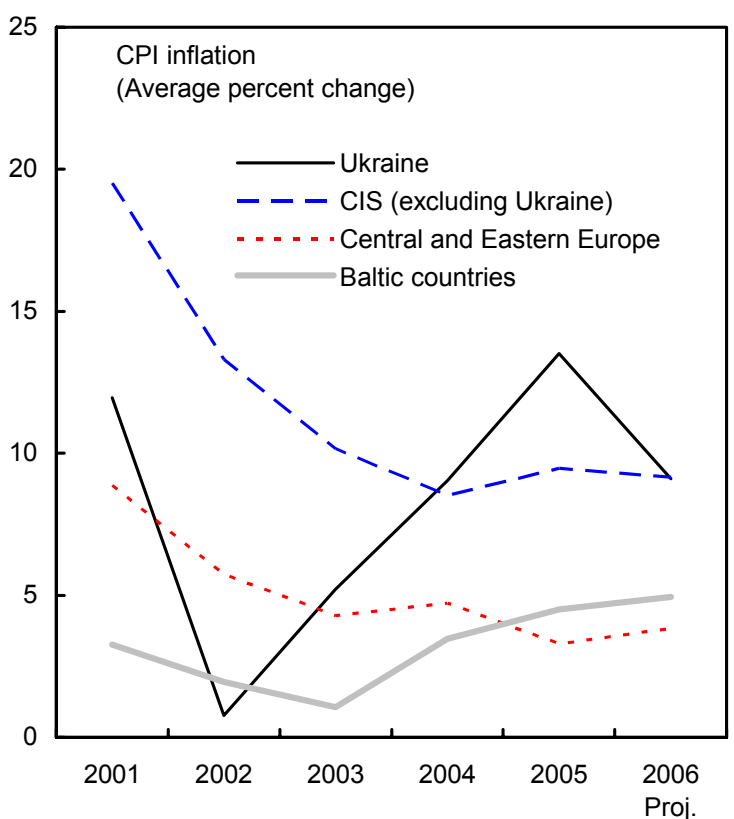

... while gyrations in unit labor costs account mostly for the volatile GDP deflator.

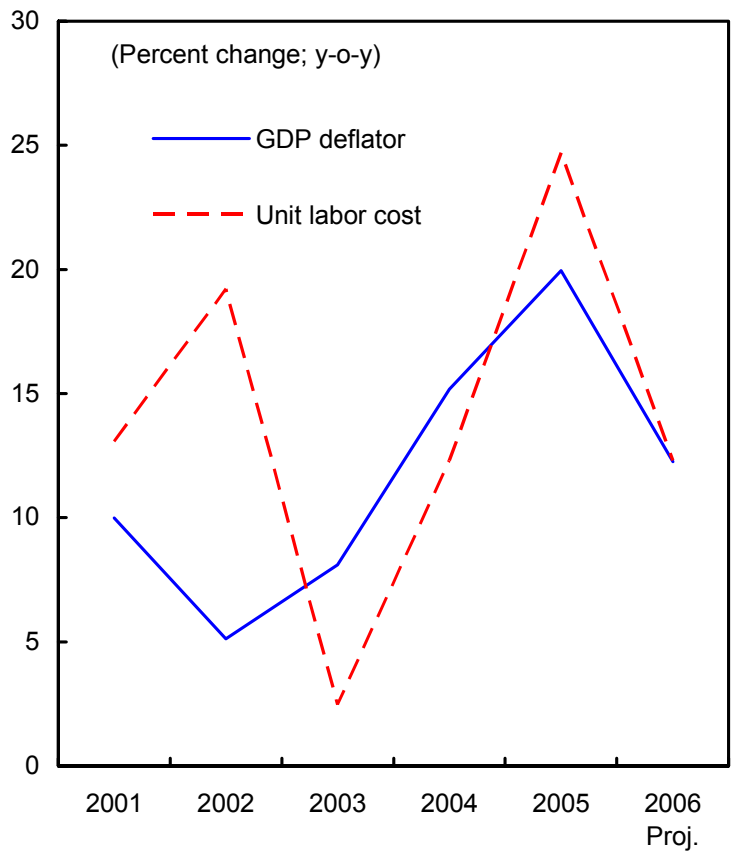

Volatile CPI inflation reflects the high volatility in the import and GDP deflators...

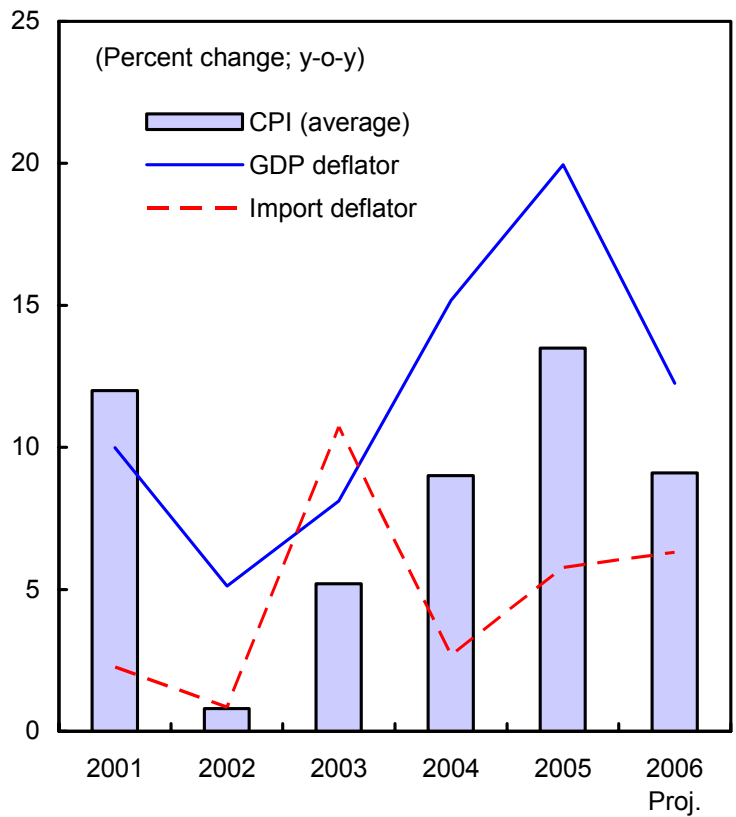

Recently, both producer and consumer prices have started to pick up again, reflecting mainly rising energy prices.

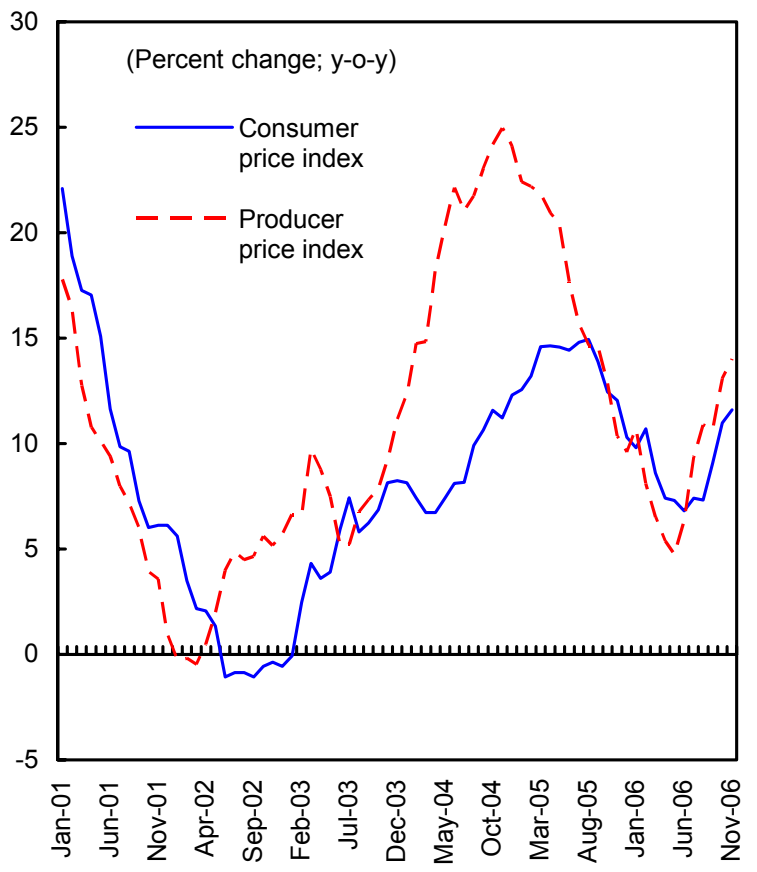

Sources: Ukrainian authorities; IMF International Financial Statistics; and staff estimates. 
energy import price hikes accelerated in late-2006, inflation accelerated back into the doubledigit range. Domestic price pressures, as measured by the GDP deflator and labor costs, have remained significant throughout this period.

\section{External fundamentals have become better balanced but remain in flux.}

5. Ukraine's steep terms-of-trade gains came to an abrupt halt in 2006. Prices for steel exports have skyrocketed, rising well above trend since 2003 (Figure 3). While import prices, particularly for oil, also increased sharply through 2005 , the cumulative terms-oftrade improvement during 2003-

05 still amounted to about 20 percent, boosting the current-account surplus by some 10 percent of GDP. However, in early-2006, amid an acrimonious dispute with Russia, the price of imported natural gas was hiked by 65 percent. For 2007, another price hike of some 35 percent has already been agreed, but Ukraine's gas import prices would still have to rise by over 50 percent to reach projected prices for Western Europe. This continued external vulnerability comes against the backdrop of highly inefficient energy use and an energy trade deficit that is already one of the highest among transition economies. ${ }^{1}$

\section{The current account has switched from large surpluses into deficit, but capital} flows have picked up and international reserves have reached healthy levels. With domestic demand booming, export volumes slumping, and the terms of trade reverting, the current account shifted from a surplus of 101/2 percent of GDP in 2004 to a likely deficit of 1 percent of GDP in 2006 (Table 3, Figure 4). At the same time, capital inflows, FDI in particular, have been buoyant, reflecting improved perceptions of Ukraine as an investment location. As a result, foreign-exchange reserves have more than doubled since end-2004 to about $4 \frac{1}{2}$ months of imports and are projected to exceed the level of short-term external debt at end-2006, mitigating external vulnerabilities.

\footnotetext{
${ }^{1}$ See International Energy Agency, 2006, Ukraine: Energy Policy Review 2006.
} 
Figure 3. Ukraine: Terms-of Trade and Energy Dependence Indicators

Steep rises of metal export prices in recent years, contributed to large terms-of-trade gains.

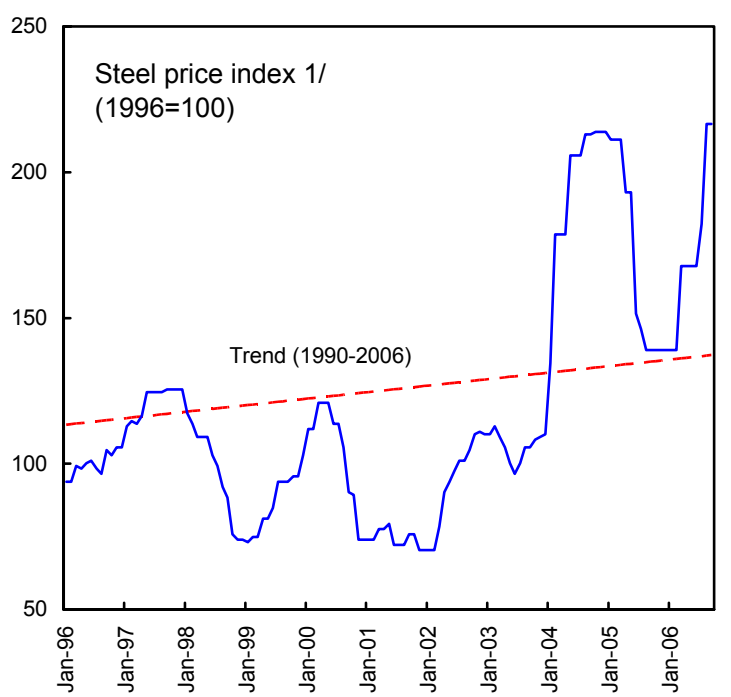

Ukraine is one of the most inefficient users of energy...

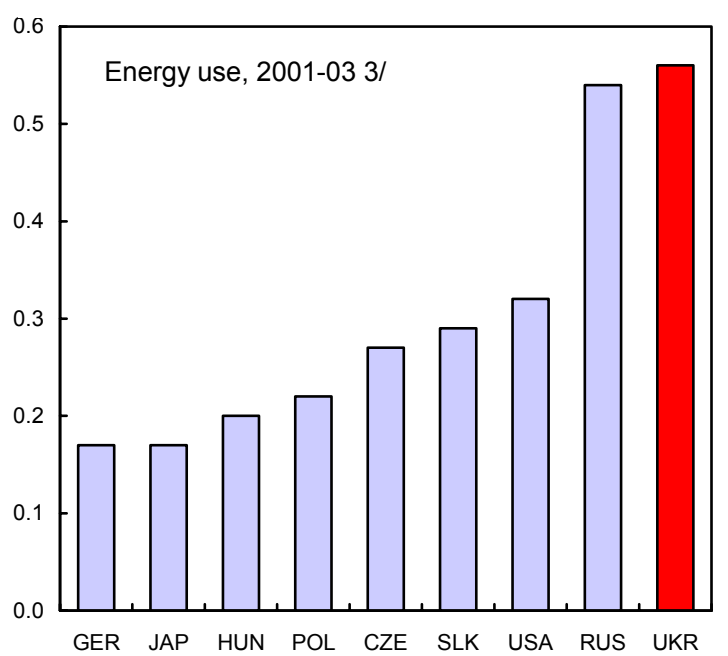

These gains came to a halt in 2006 owing to sharply higher import prices, particularly for natural gas.

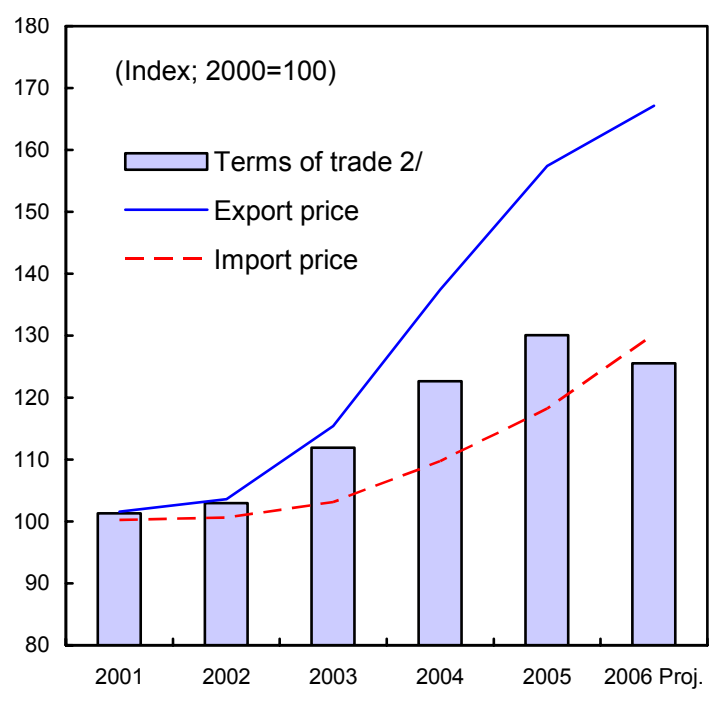

... and as a heavy net energy importer, its energy bill is highly vulnerable to price shocks.

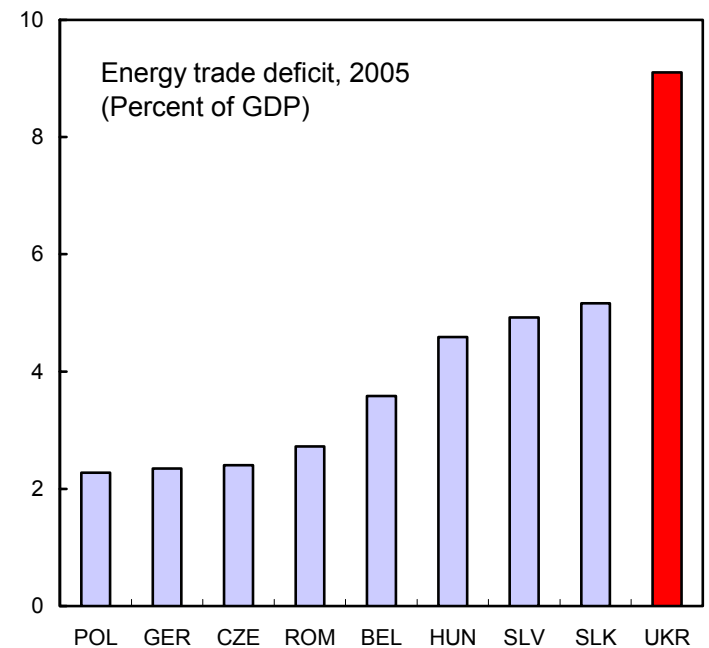

Sources: National Bank of Ukraine; International Energy Agency; Bloomberg; UN Comtrade Database; IMF International Financial Statistics; and staff estimates.

1/ Bloomberg index for export steel prices of hot rolled steel in the EU.

2/ Goods terms of trade.

3/ Kilotonnes of oil equivalent per unit of purchasing-power-parity-adjusted GDP. 
Figure 4. Ukraine: Current and Capital Account Indicators, 2001-06

The end of large current-account surpluses ...

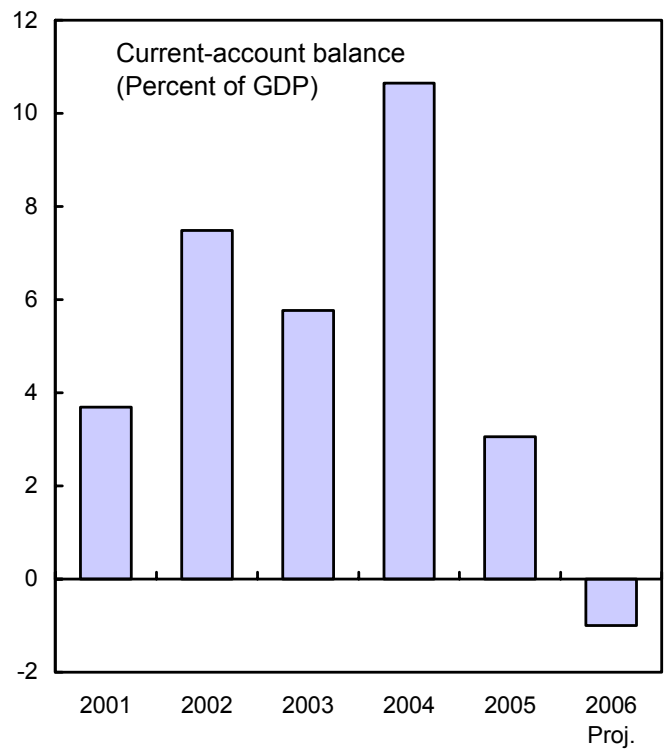

This has improved reserve coverage to comfortable levels...

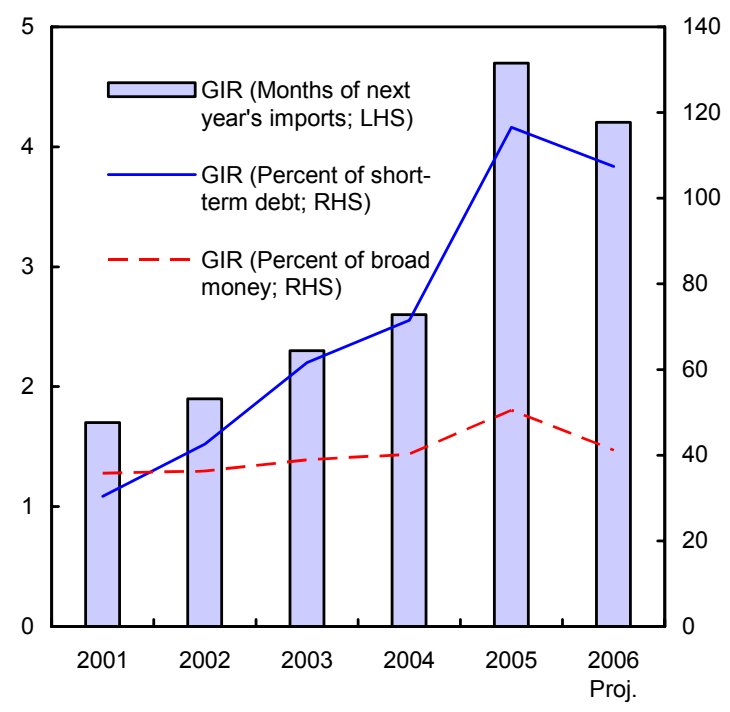

... was largely compensated by net capital inflows in 2005-06.

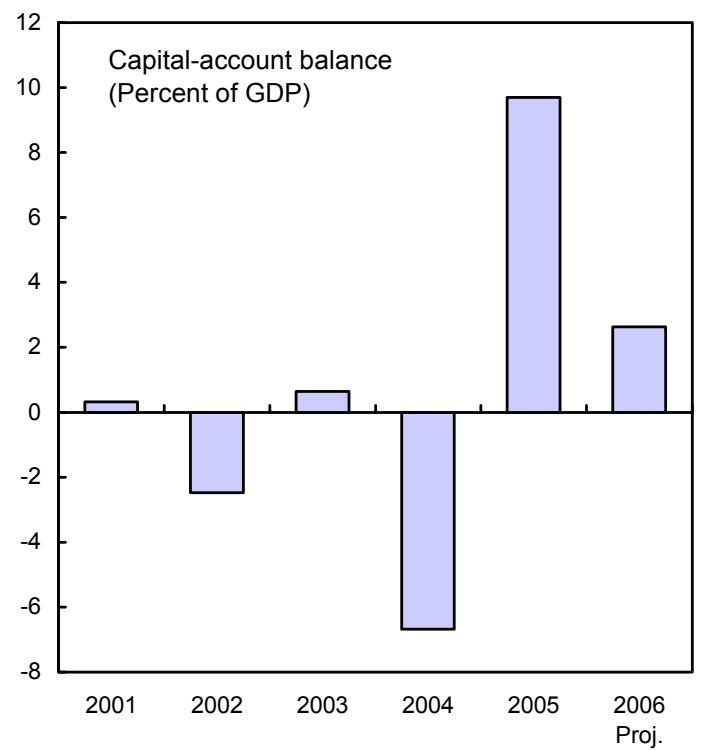

... while spreads for Ukraine's eurobonds remain broadly in line with its country rating.

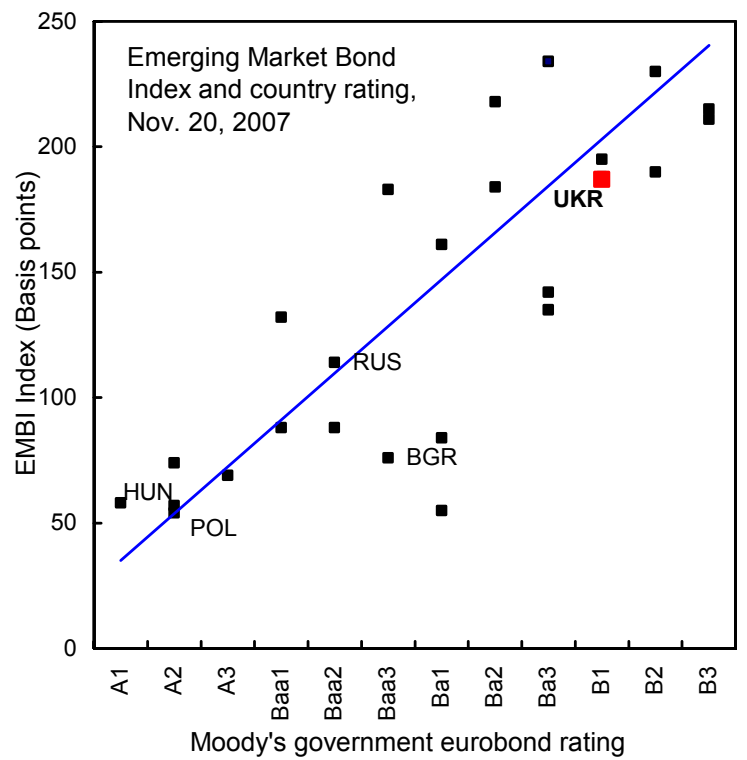

Sources: National Bank of Ukraine; Bloomberg; Moody's Investors Service; and staff estimates. 
7. The hryvnia's real undervaluation has narrowed considerably. Staff work in 2004 suggested that the hryvnia was heavily undervalued in real terms, although quantitative estimates varied widely. A re-assessment using the latest data and based on the IMF's macroeconomic-balance approach points to a much reduced gap between Ukraine's actual and estimated equilibrium current account (Figure 5). ${ }^{2}$ This analysis suggests a real effective exchange rate undervaluation of between 3 and 15 percent. Alternative approaches based on purchasing-power-parity and dollar-wage comparisons across countries are broadly consistent with this assessment. However, these approaches also highlight that Ukraine's real effective exchange rate should be expected to appreciate substantially over the longer term as its per capita income catches up with more advanced economies.

Notwithstanding low fiscal deficits, spending and tax policies have shifted the economy on to a high-consumption path.

8. The authorities have proven adept at hitting low fiscal deficit targets, and explicit public debt has plunged. The 1998 financial crisis, which was triggered by the government's inability to roll over its short-term debt, has left fiscal-policy makers with an acute sense of vulnerabilities related to high deficits and debt. Thus, in 2005, despite a slowing economy and no financing constraints (privatization receipts alone reached 5 percent of GDP), the tight general government cash deficit target of $2 \frac{1}{2}$ percent of GDP was easily met. Through November 2006, the authorities seemed on track to undershoot the 3 percent of GDP annual deficit target (Table 5). The combination of low deficits and strong nominal growth has reduced explicit public debt to about 17 percent of GDP, down from over 60 percent in 1999. However, contingent liabilities remain high at some 30 percent of GDP, largely reflecting the so-called lost-savings deposits (Box 2), but also implicit contingent liabilities of state enterprises.

\section{Reflecting a redistributionist shift in fiscal policy, recurrent spending and tax} collections from businesses have both ratcheted upward. In 2005, average public wages and pensions were raised by over 50 percent (against an inflation target of just under 10 percent). As a result, pension spending commitments soared from 12 percent of GDP in 2004 to about 17 percent in 2005, likely the world's highest ratio (Figure 6). To finance this recurrent-spending boom, while reducing the fiscal deficit, the government curtailed capital spending by some 13/4 percent of GDP and raised tax collections by some 6 percent of GDP, the latter especially through canceling tax breaks for the free economic zones (FEZs) and administrative improvements. The 2006 budget largely preserved the thrust of these policies.

\footnotetext{
${ }^{2}$ See Selected Issues Chapter II "Monetary and Exchange Rate Policy Framework—Where to Go from Here?"
} 
Figure 5. Ukraine: Indicators of External Competitiveness, 1995-2006

Partly owing to Ukraine's large real appreciation in 2005-06, ...

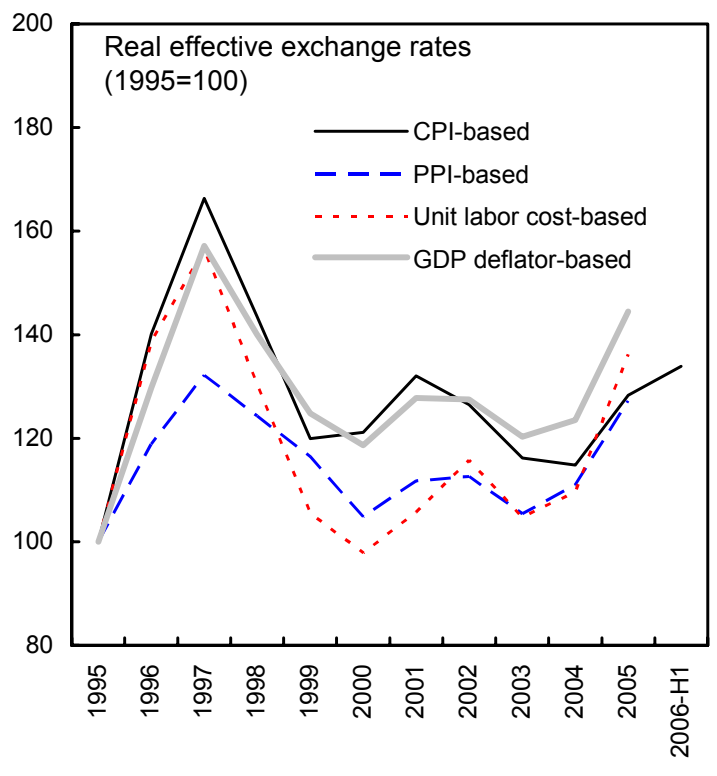

Ukraine's dollar-wage cost indicator is broadly in line with its per capita income...

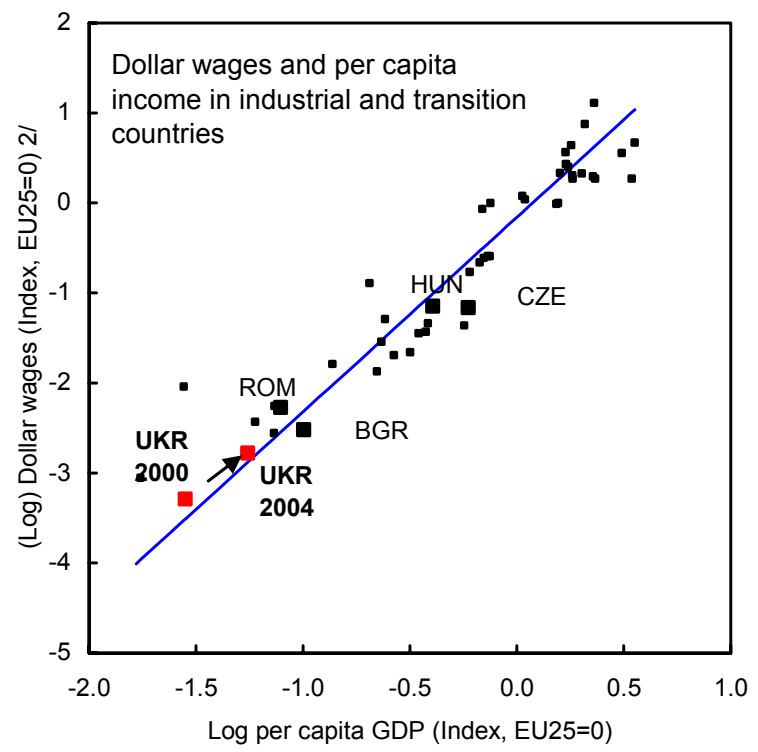

... the gap between the actual and the equilibrium current account balance has narrowed sharply.

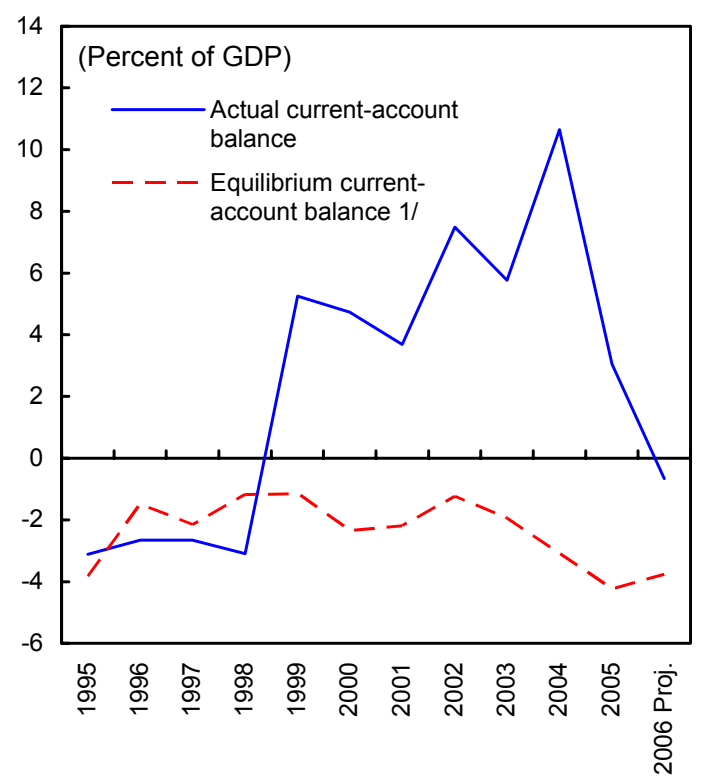

... while estimates based on purchasing power parity indicate some undervaluation.

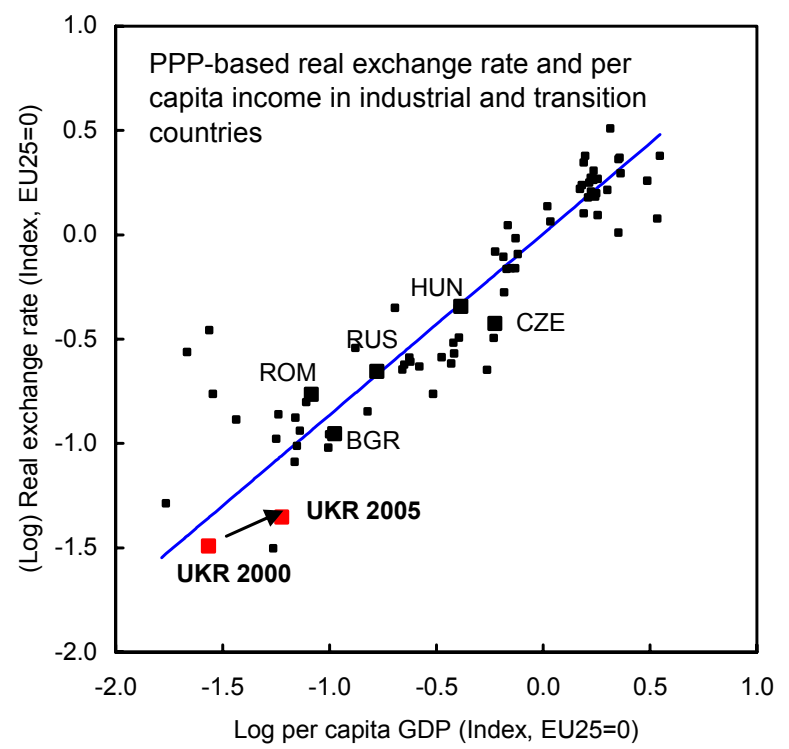

Sources: Ukrainian authorities; IMF International Financial Statistics; and staff estimates.

1/ The estimated equilibrium current account is the level of the current account consistent with external balance over the medium term. For more details see Selected Issues Chapter II "Monetary and Exchange Rate Policy Framework—Where to go From Here?"

2/ Average monthly wages in manufacturing. 
Figure 6. Ukraine: Indicators of Fiscal Policy, 1999-2006

A broadly neutral fiscal-policy stance in 2006 followed on the tightening in 2005.

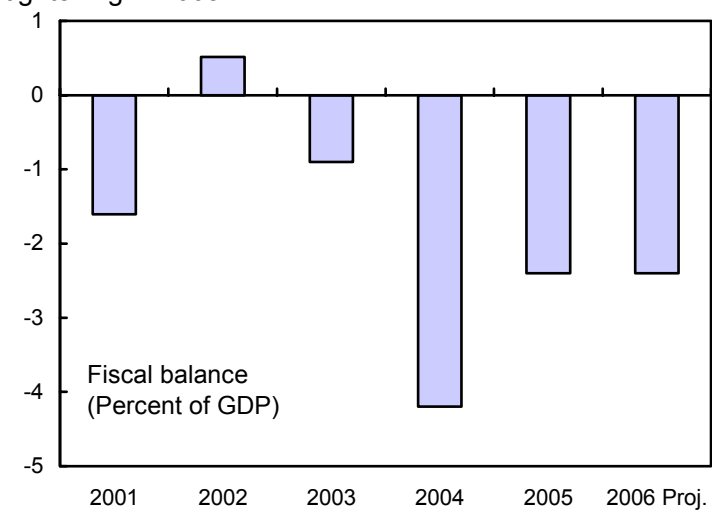

$\ldots$ and the state-enterprise sector continues to be a significant drain on the budget.

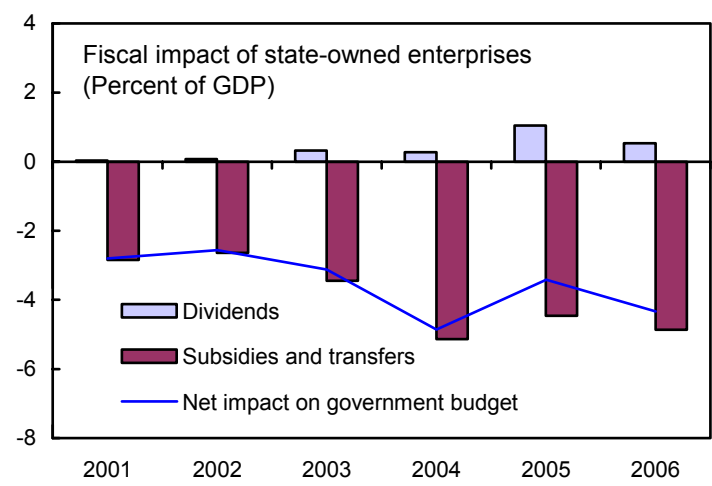

As a result, Ukraine's revenue-to-GDP ratio is now quite high...

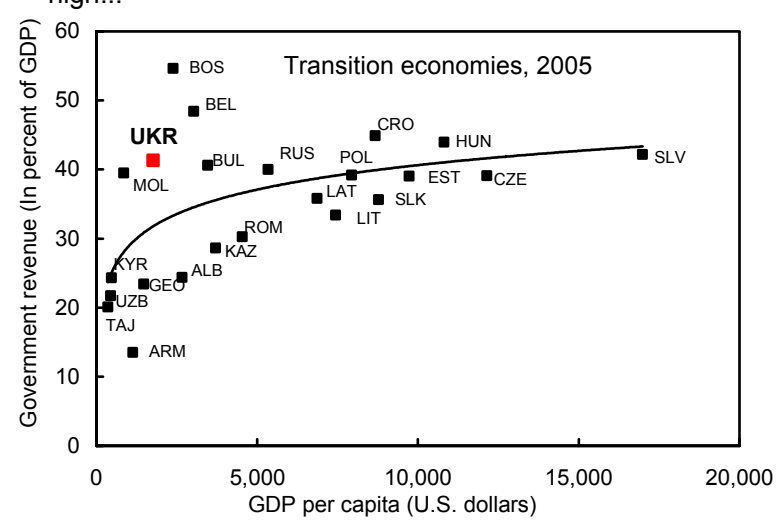

Public debt has plunged, but contingent liabilities remain significant...

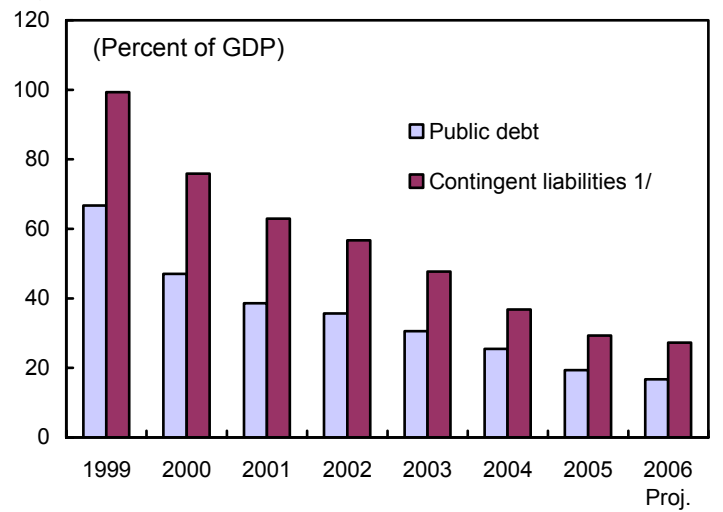

At the same time, recurrent spending has ratcheted up, requiring sharp increases in the tax burden.

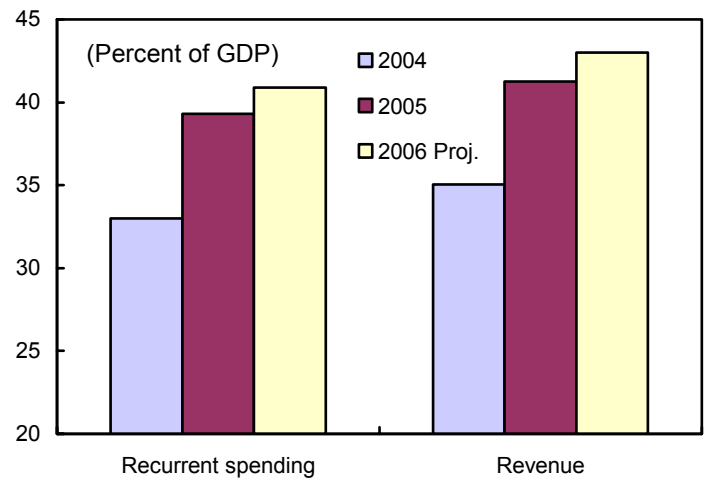

...and the pension spending-to-GDP ratio likely the highest in the world.

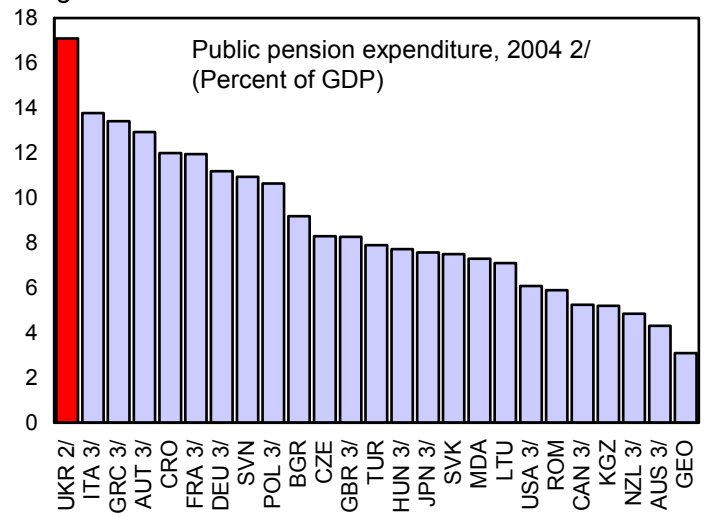

Sources: Ukrainian authorities; IMF World Economic Outlook; OECD; and staff estimates.

$1 /$ Estimated contingent liabilities from the so-called lost-savings deposits (see Box 2).

2/ 2005 for Ukraine, including military pensions.

3/ Data are for 2001. 


\section{Box 2. Ukraine' Lost-Savings Problem}

The savings deposits of Ukrainian citizens depreciated to almost nothing during the early1990s hyperinflation. But the deposits were recognized as a government liability in 1996, amounting then to about 160 percent of GDP. However, the law only requires a minimum annual repayment of about 0.1 percent of GDP, and since the liability was neither indexed nor paid interest, it has shrunk to some 24 percent of GDP. Recently, there have been several proposals to speed up repayment, which, if implemented, could significantly ratchet up the fiscal cost of resolving the lost-savings problem.

Ukraine: Net Present Value of Lost Savings Repayment Proposals

\begin{tabular}{lccc}
\hline Settlement Proposals & $\begin{array}{c}\text { Net Present } \\
\text { Value of } \\
\text { Proposal 1/ }\end{array}$ & $\begin{array}{c}\text { Maximum } \\
\text { Annual } \\
\text { Payment }\end{array}$ & $\begin{array}{c}\text { Completion } \\
\text { Date }\end{array}$ \\
\hline \multicolumn{4}{c}{ (In percent of GDP) } \\
Status quo & 0.9 & 0.1 & 2250 \\
Parliament (2002) & 23.0 & 2.9 & 2014 \\
Parliament (2005) & 15.3 & 1.4 & 2015 \\
President (2005) & 3.7 or 5.5 & 0.2 & 2043 or 2028 \\
\hline
\end{tabular}

Source: Staff estimates.

1/ Calculation assumes real GDP growth of 5 percent, nominal GDP growth of 11 percent, and a nominal interest rate of 12 percent.

\section{The monetary framework has remained anchored by a de facto peg.}

10. Monetary conditions have continued to adjust passively to the requirements of the peg and are currently loose. Although the NBU has allowed the interbank exchange rate to fluctuate within a narrow band of Hrv/US\$5.00-5.06, the exchange-rate regime has remained a de facto peg. In this setting, base money growth has been mostly driven by foreign-exchange interventions and changes in the government's deposits at the NBU (Figure 7, Table 6). During most of 2006, the NBU's monetary reactions implied an automatic tightening of its stance, only partly off-set by lower reserve requirements and a cut in NBU interest rates. More recently, monetary conditions have loosened again, reflecting a pickup in foreign-reserve accumulation and drawdown of government deposits. Real shortterm interest rates have remained highly negative throughout this period. 


\section{Booming credit and increasing loan dollarization have heightened banking-sector risks.}

\section{A long-lasting credit boom has increased the balance-sheet vulnerabilities of} banks and their borrowers. ${ }^{3}$ With real credit growth of about 40 percent annually since 2001, Ukraine's domestic credit boom has been one of the fastest among transition economies (Figure 8). At the same time, corporates and banks have continued to borrow heavily abroad. As a result, overall corporate sector debt- two thirds of which is in foreign currencynow exceeds 50 percent of GDP. Household sector debt, also mostly in foreign currency, has surged over the past 18 months, albeit from a low level. These developments have translated into substantial indirect foreign-currency risk for banks since most borrowers are unhedged. Banks are also faced with

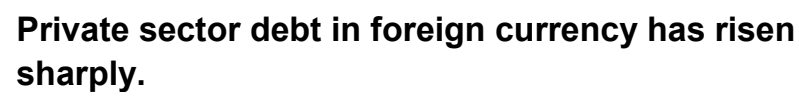
Private sector debt in foreign currency has risen sharply.

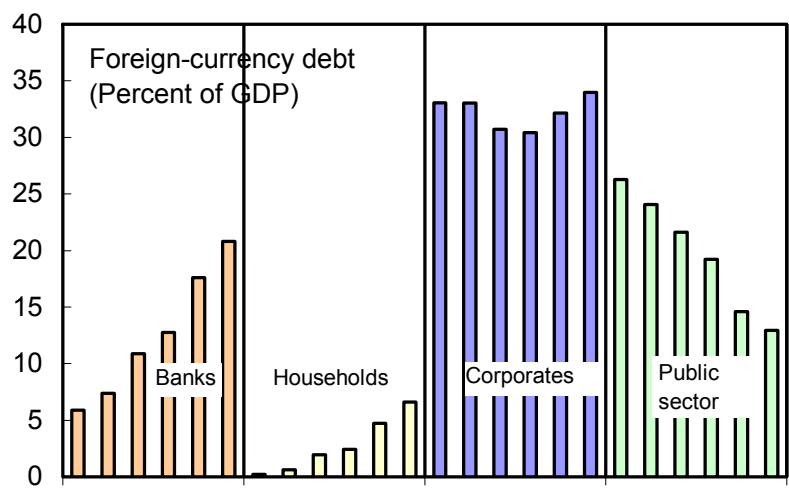

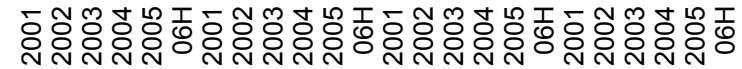

Sources: National Bank of Ukraine; and staff estimates. rising foreign-currency liquidity risk, reflecting their increased reliance on short-term foreign funding (Table 7). While an influx of foreign banks since 2005 likely had a beneficial effect on credit-risk management practices, recent financial soundness indicators, particularly declining capital-adequacy ratios, suggest that the sector as a whole continues to be vulnerable to downside risks.

12. Financial markets remain heavily underdeveloped. While equity-market capitalization is relatively high, daily turnover is miniscule and individual stock prices move in lockstep, suggesting that the market plays little role in allocating capital across companies (Figure 9). The government-securities market has also stayed illiquid and shallow, reflecting strong preferences toward foreign financing: between August 2005 and October 2006, no significant primary issuances took place. Finally, the size and liquidity of foreign-exchange markets, including forward markets for hedging exchange-rate risks, has been constrained by the de facto peg and a sizeable tax on non-cash foreign-exchange transactions.

\footnotetext{
${ }^{3}$ See Selected Issues Chapter III "Financial Dollarization in Ukraine—Roots and Risks."
} 
Figure 7. Ukraine: Monetary Policy Indicators, 2004-06

Increased exchange-rate flexibility since 2005 has been limited to a 1 percent corridor...

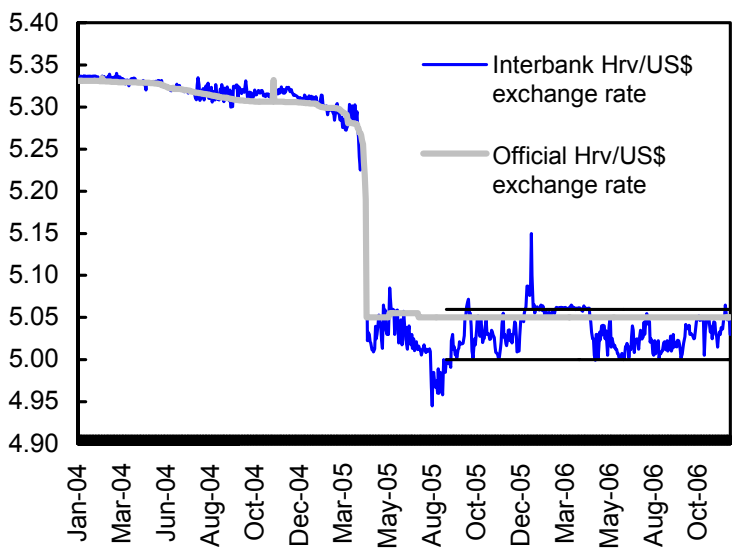

....as the NBU continued to intervene in the foreignexchange market.

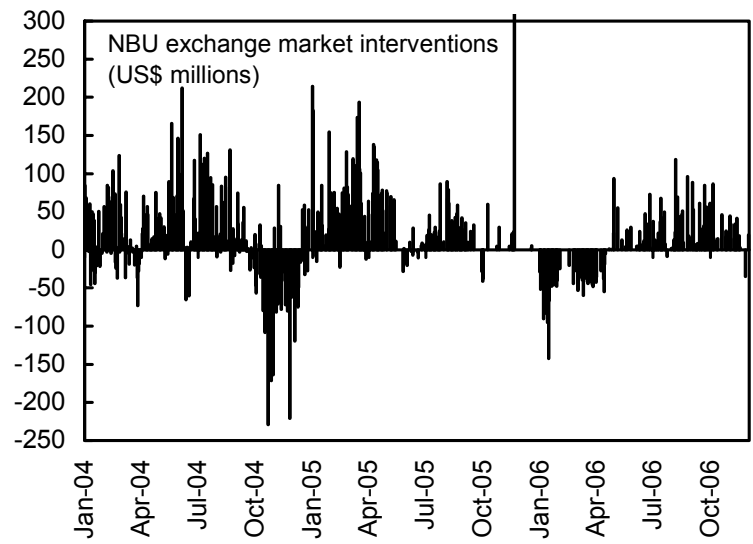

Reflecting the peg, base money has been driven mostly by foreignexchange interventions and changes in government deposits, ...

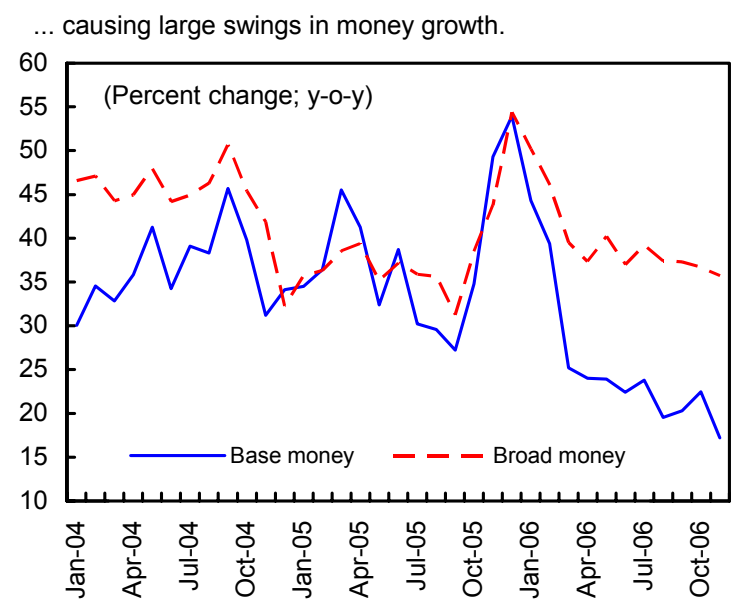

More recently, monetary conditions have loosened again, reflected in rising banks' excess liquidity...

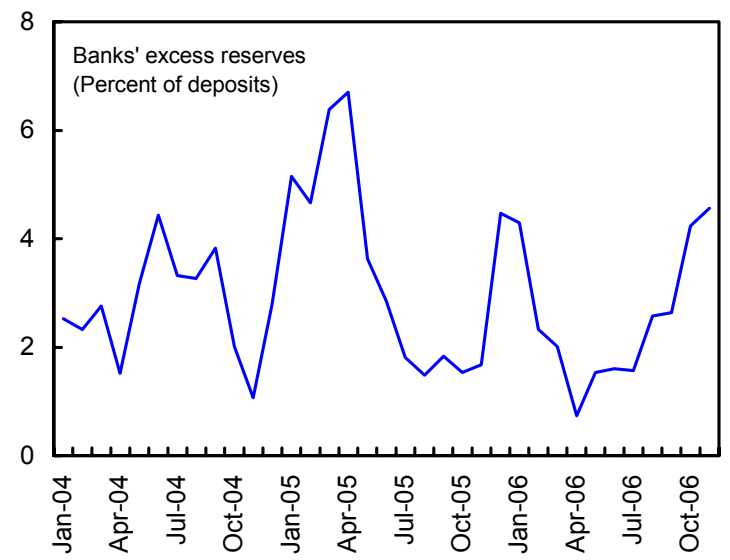

... and falling and highly negative real money market rates.

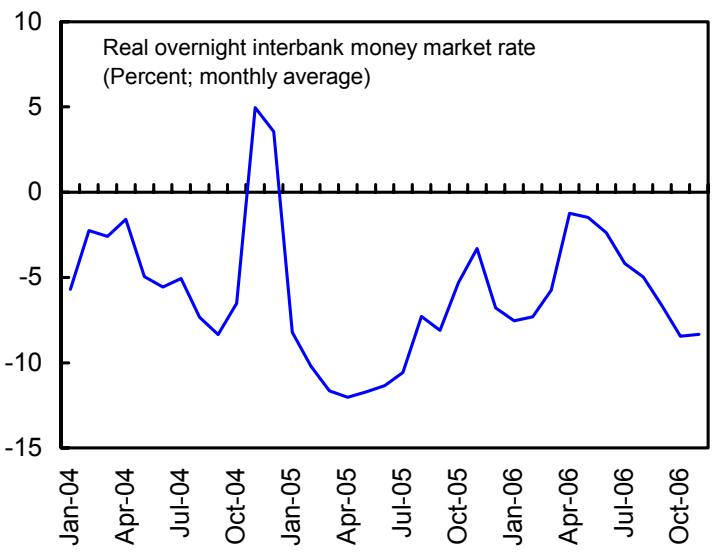

Sources: National Bank of Ukraine; and staff estimates. 
Figure 8. Ukraine: Indicators of Banking Sector Risks, 2001-06

Ukraine has had one of the most pronounced credit booms among transition economies.

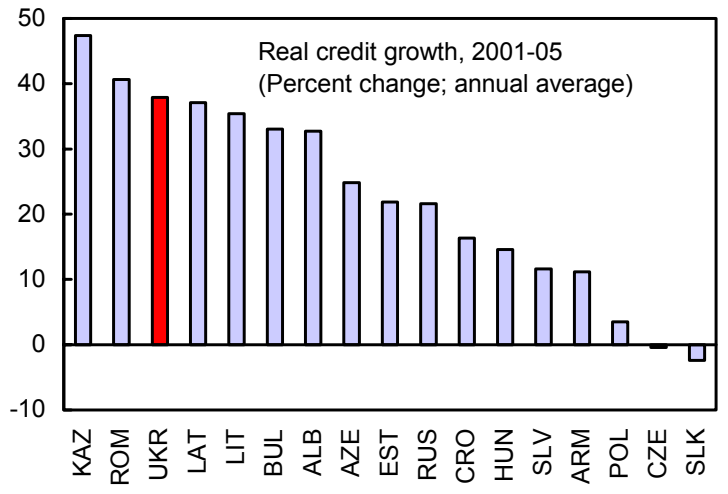

More recently, household loans have provided new momentum to the credit boom...

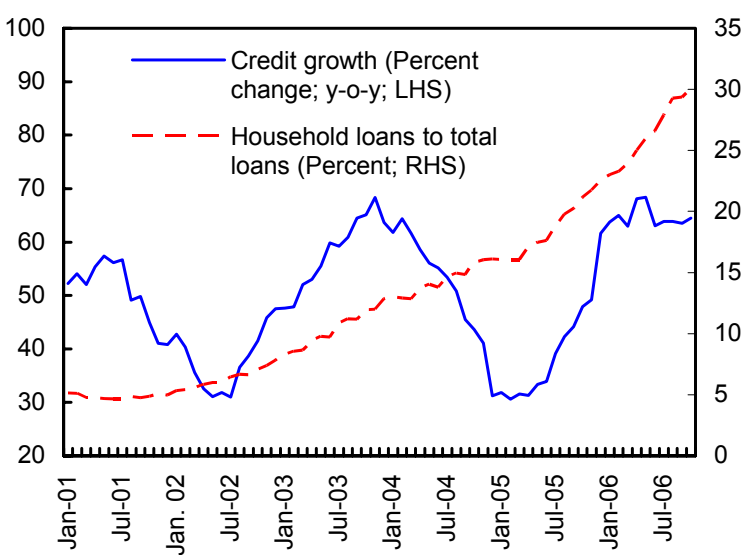

At the same time, banks' rising short-term external borrowing creates new risks.

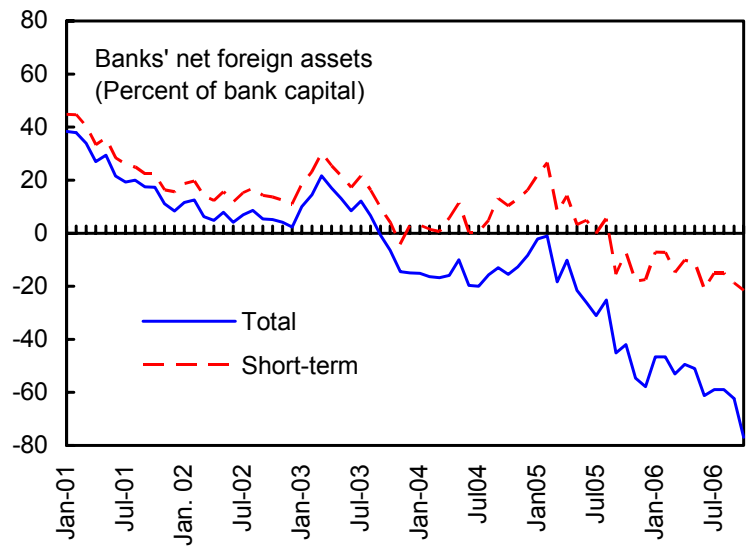

Corporates' overall debt already exceeds levels in more advanced peers.

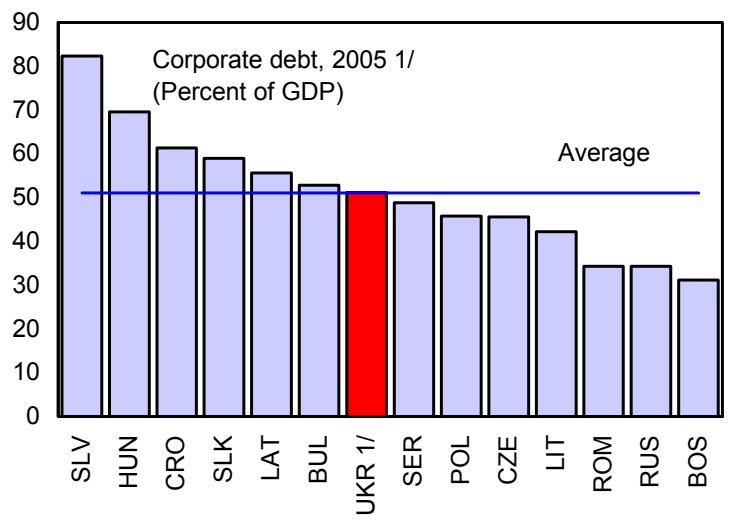

... with the majority of loans denominated in foreign currency, thus raising banks' indirect foreign-exchange risk.

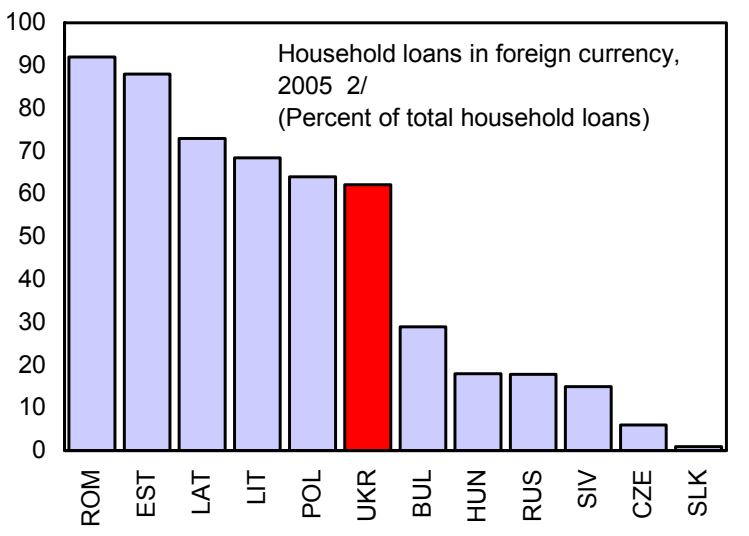

While these are mitigated by the influx of foreign banks, they could fuel even higher foreign borrowing going forward.

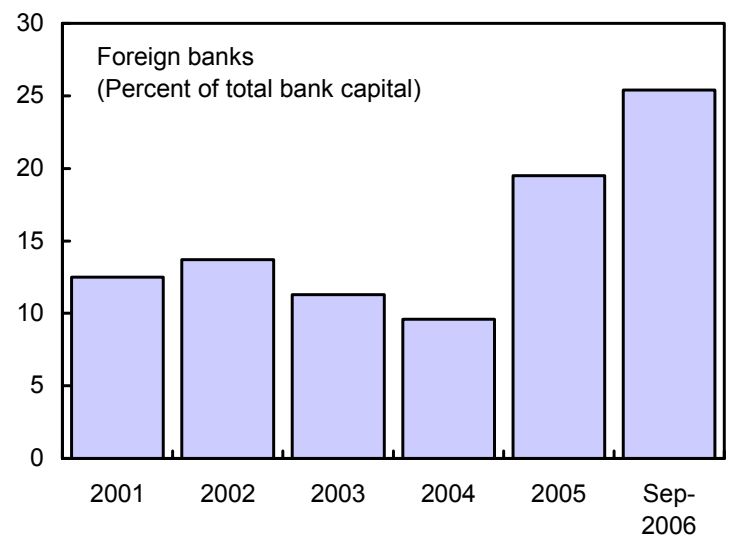

Sources: National Bank of Ukraine; and staff estimates.

1/ Bank loans and external debt; June 2006 for Ukraine.

2/ September 2006 for Ukraine. 
Figure 9. Ukraine: Financial Market Development Indicators

While capitalization of equity markets in Ukraine is already relatively high...

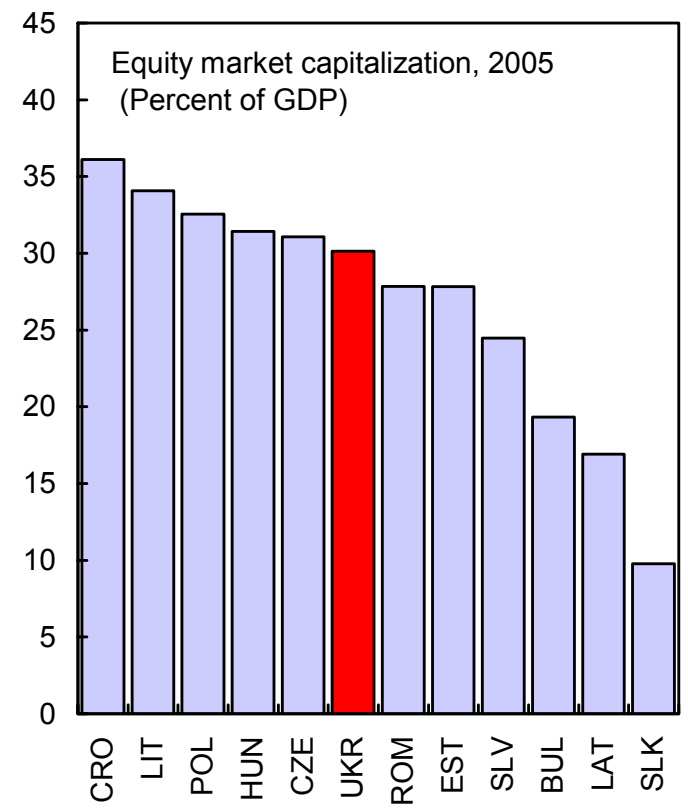

A low stock of domestic government debt has contributed to shallow securities markets.

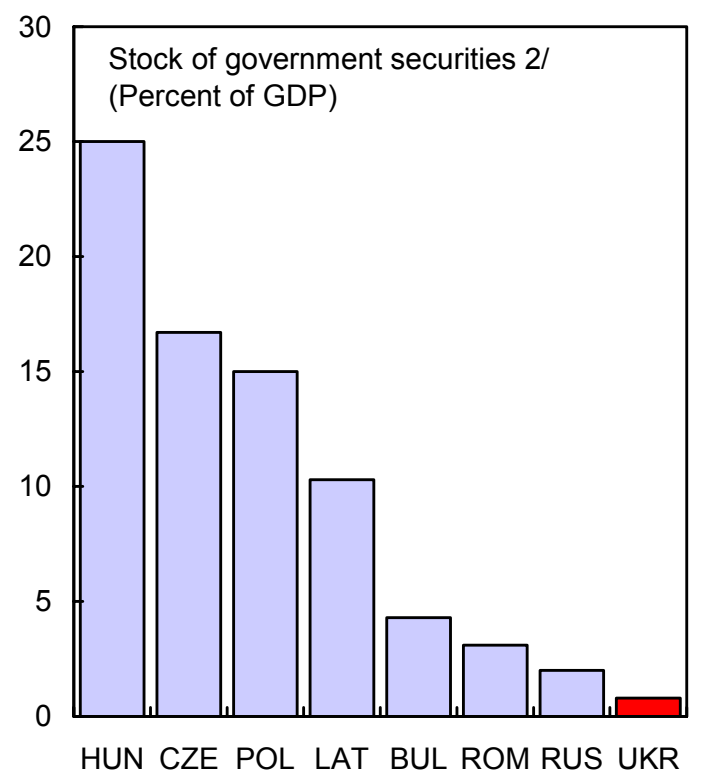

... trading activity on organized markets is minimal.

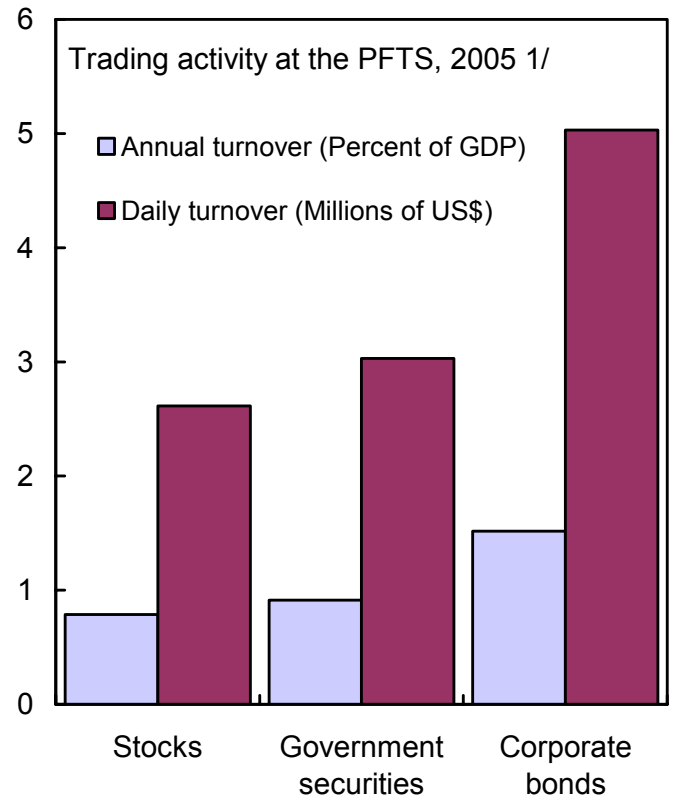

And activity on the foreign-exchange market was hampered by the foreign-exchange transaction tax.

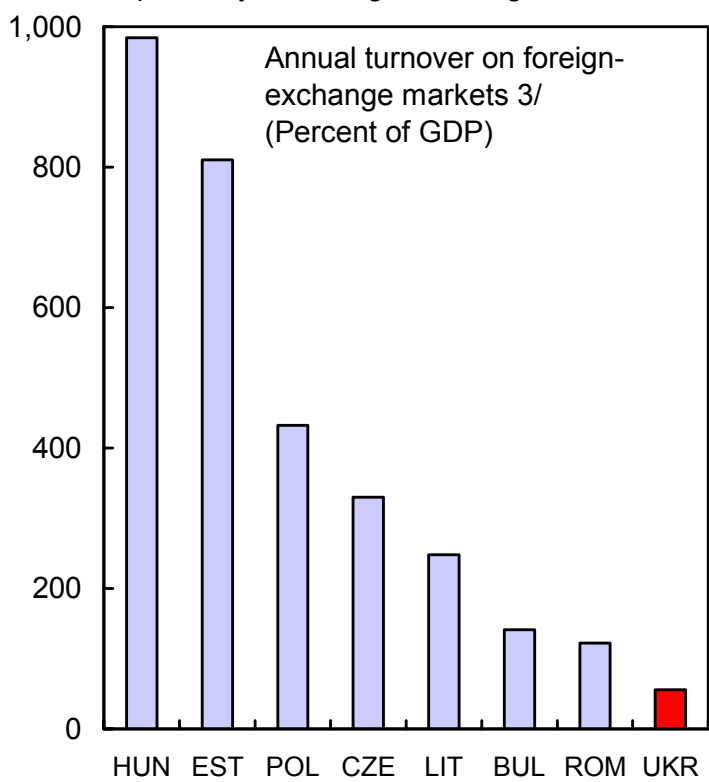

Sources: First Securities Trading System (PFTS); Federation of European Securities Exchanges; European Central Bank; National Bank of Ukraine; and staff estimates.

1/ The PFTS (First Securities Trading System) accounts for nearly 90 percent of regulated market activities in Ukraine.

2/ September 2006 for Ukraine; 2003 for Bulgaria and Romania; 2002 for Russia, Hungary, and Poland; and 2001 for Latvia and the Czech Republic.

3/ 2006 for Ukraine and Bulgaria; 2005 for Romania; and 2001 for other countries. 


\section{REPORT ON THE DISCUSSIONS}

\section{The authorities and staff agreed that Ukraine faced interconnected}

macroeconomic challenges. With external uncertainties looming large, discussions focused on the appropriate monetary and fiscal frameworks - both key to adjust to external shocks and control inflation - and measures to address rising banking-sector risks. At the same time, unlocking convergence growth clearly remains Ukraine's key longer-term challenge, and discussions also covered growth strategies.

\section{A. Macroeconomic Outlook}

14. There was agreement that Ukraine's external environment was highly uncertain. Natural gas prices were expected to rise further toward Western European levels over the medium term, and this would undoubtedly have adverse implications for growth, inflation, and the current account. ${ }^{4}$ Less clear was the scope for raising energy efficiency and, consequently, lowering energy-import volumes. On the export side, prices for steel were surrounded by large margins of uncertainty: some observers (producers) foresaw continuing increases, while others (traders) expected declines. Finally, it was difficult to discern how capital flows, FDI in particular, would respond to different combinations of shocks and policies. ${ }^{5}$

\section{The authorities' external outlook was much more favorable than that of staff.} They expected benign conditions: sharply higher export prices for steel; falling non-energy import prices; and strong capital inflows. By contrast, under staff's external baseline, steel prices would revert toward trend over the medium term in line with the WEO's metal price projections, and non-energy import prices would follow WEO export-price trends in Ukraine's trading partners. As a result, most of Ukraine's recent terms-of-trade gains would be reversed over the next five years (Figure 10). In staff's external baseline, depending on policies, the current-account deficit could be pushed well beyond reasonable estimates of the equilibrium deficit, resulting in real overvaluation.

\section{The authorities planned several significant policy changes, and, given their} benign external outlook, expected the economy to perform well over the medium term. Most notably, recent budgetary policies that had cut into national savings would be reversed, with public wages and transfers restrained to reduce consumption growth. Assuming favorable terms-of-trade developments, the authorities saw these policies as sufficient to restore the previous pattern of large current-account surpluses. With budgetary savings, the authorities intended to raise public-sector investment, particularly in the energy sector, to

\footnotetext{
${ }^{4}$ See Selected Issues Chapter I "The Macroeconomic and Fiscal Impacts of Energy Price Shocks in Ukraine.”

${ }^{5}$ Another external uncertainty relates to potentially significant receipts from trading carbo emission rights under the Kyoto Protocol.
} 
Figure10. Ukraine: External Terms of Trade, 2000-11 1/

The outlook for the terms of trade has deteriorated sharply...

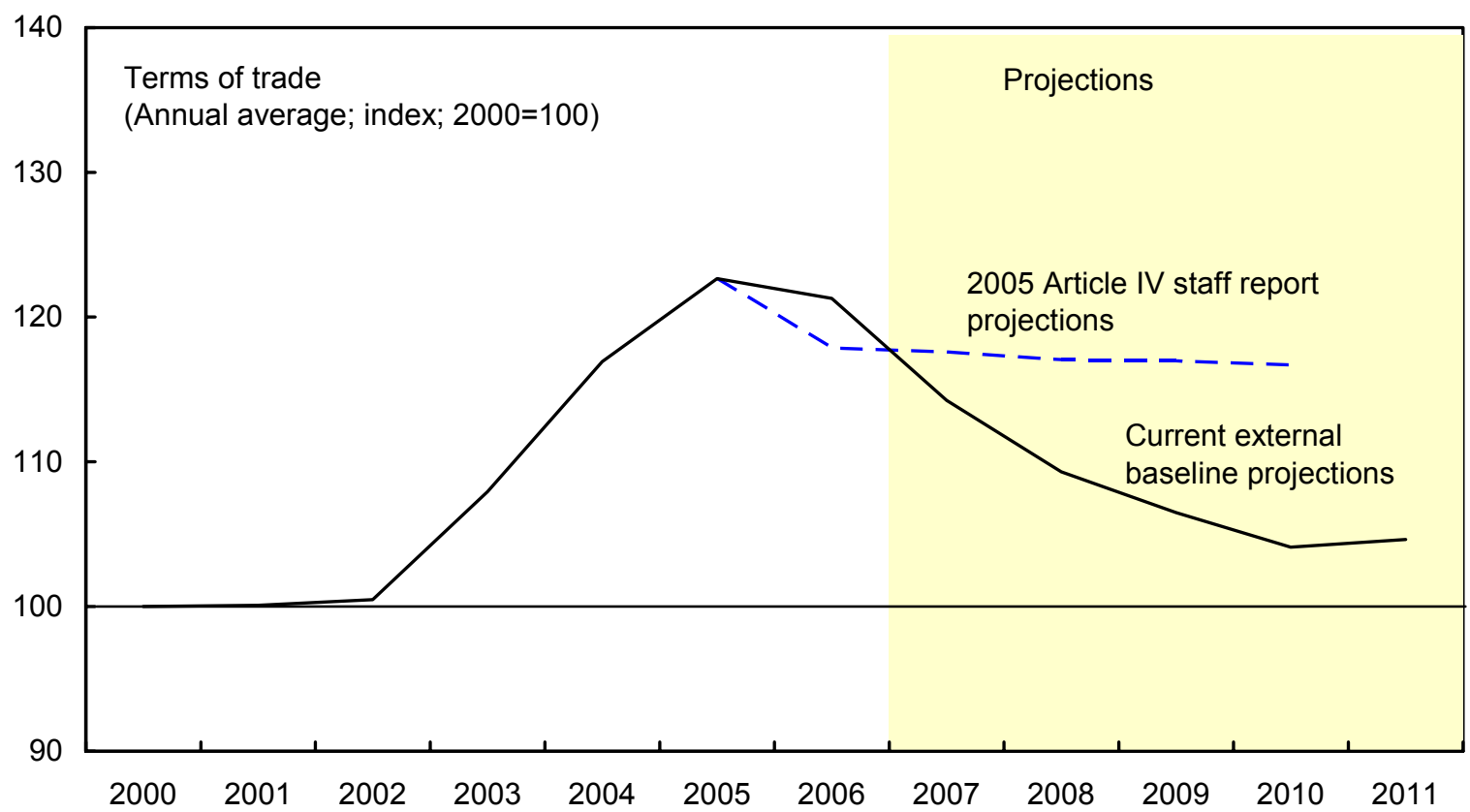

... reflecting higher gas import prices but also due to expected reductions in steel export prices.

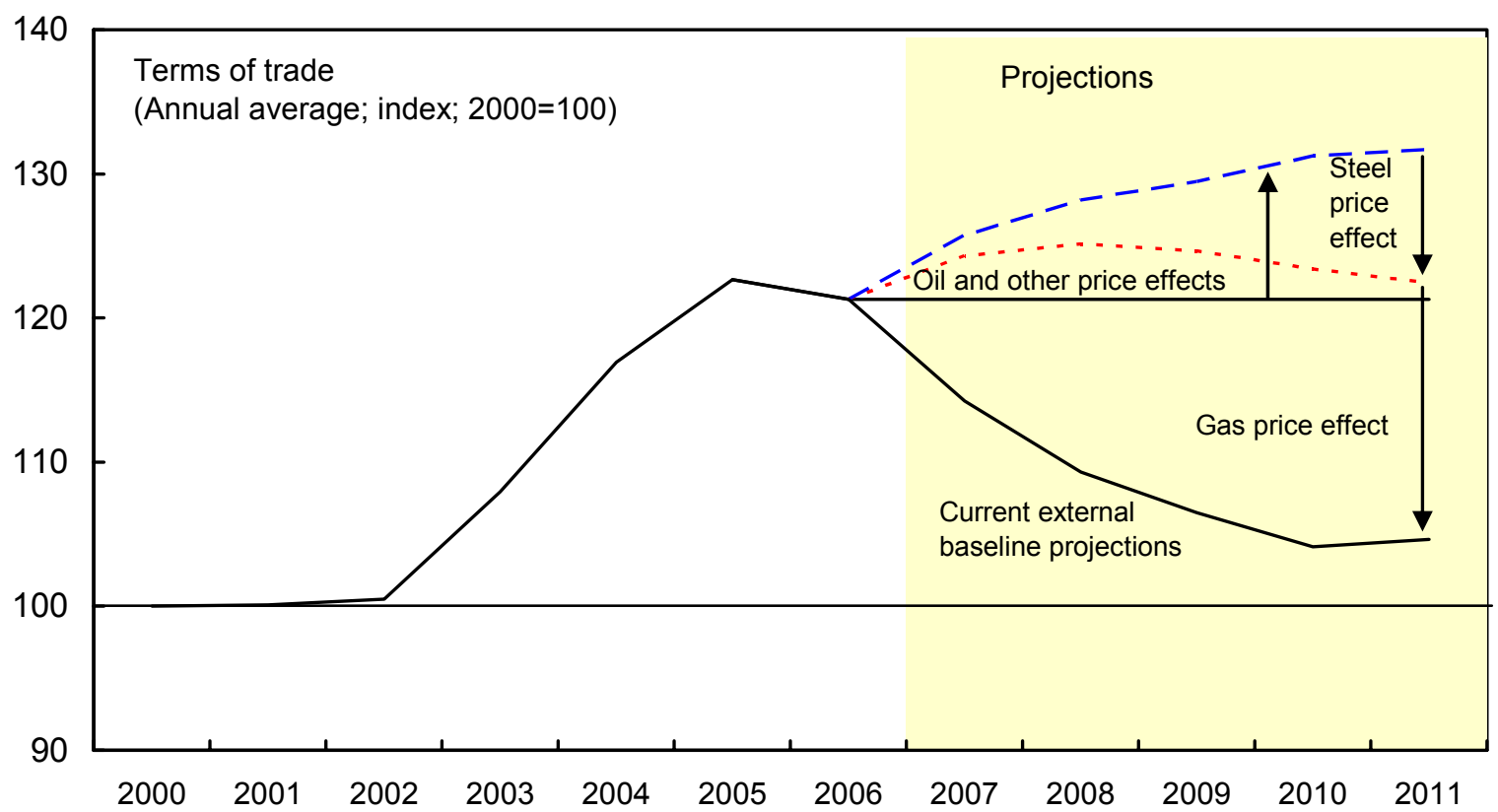

Sources: National Bank of Ukraine; IMF World Economic Outlook; and staff estimates. 
mitigate the impact of rising gas-import prices. A range of tax preferences, subsidies, and structural reforms would spur higher private investment. In this environment, FDI inflows would be buoyant, and growth robust in the 6-7 percent range. A stable nominal exchange rate, careful management of supplies in domestic markets, and administered price restraint would bring CPI inflation down and keep it in single digits.

\section{Staff analysis suggested, however, that the authorities' policies could create medium-term macroeconomic tensions, both under staff's baseline and a benign external outlook.}

- Under the baseline external outlook, CPI inflation could still drop to just over 8 percent in 2007, since the authorities do not intend to pass through higher energy prices to consumers (Figure 11, Table 8). However, over the medium term, the combination of negative external shocks and a pegged nominal exchange rate could result in currency overvaluation, rising current-account deficits, and falling international reserves. This would not be an environment where capital inflows would be buoyant, nor would growth be strong.

- $\quad$ Under the baseline external outlook, there could be risks to external debt sustainability. Ukraine's gross external debt would rise, reflecting increasing currentaccount deficits; moreover, in response to an array of other adverse shocks, it could reach uncomfortably high levels. Public debt sustainability would be maintained, although large-scale realization of contingent liabilities could ratchet it up considerably. (Appendix I).

- In contrast, under a benign external outlook and the authorities' likely policies, including a maintained peg, the currency would likely remain undervalued. Given past monetary-policy behavior under the peg, the authorities might not be able or willing to sterilize large foreign-exchange interventions. Monetary expansion could therefore lead to medium-term inflationary pressure regardless of administrative price restraints.

\section{More robust policies would therefore be needed to forestall medium-term} macroeconomic tensions. Staff saw the authorities' fiscal framework and incomes-policy intentions as broadly appropriate. However, the authorities should allow pass-through of higher energy import prices not only to producers but also consumers, shift to a monetary framework based on a more flexible exchange-rate regime, and restrain second-round inflation effects of higher energy prices through an appropriately tight monetary stance. These policies should be seen as a package: not implementing some recommended policies could put too high a burden on other policy areas.

19. The recommended policy frameworks would allow the authorities to cope with both baseline and benign external outlooks. Under the baseline external outlook, current- 


\section{Figure 11. Ukraine: Macroeconomic Prospects Under Alternative Scenarios 1/}

Authorities' Policies 2/

External headwinds and competitiveness problems could hold down growth...

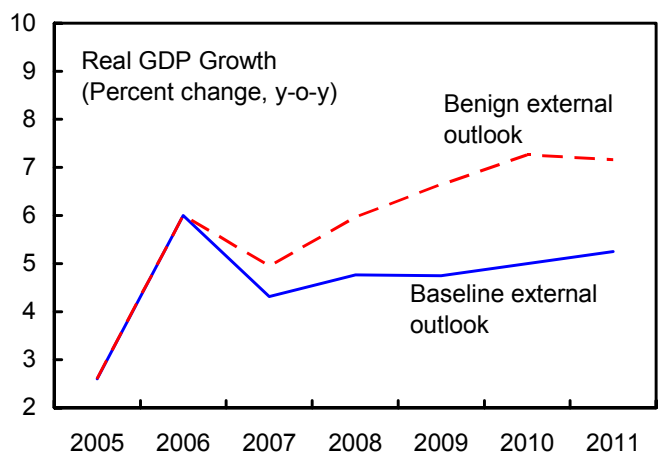

...but if the external environment were to be benign, inflation could remain elevated.

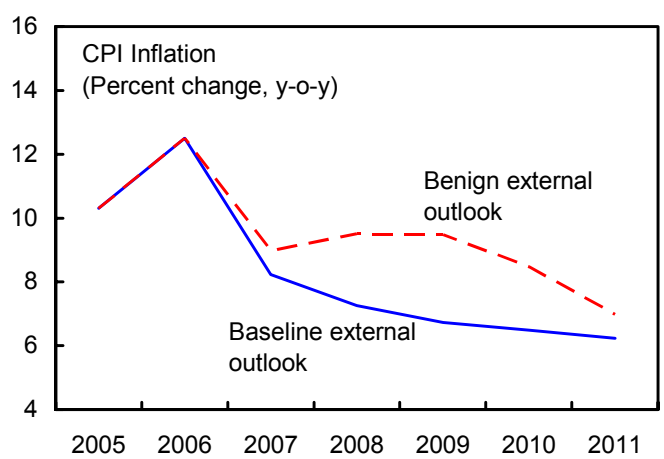

External headwinds and a currency peg could lead to steep declines in reserve coverage.

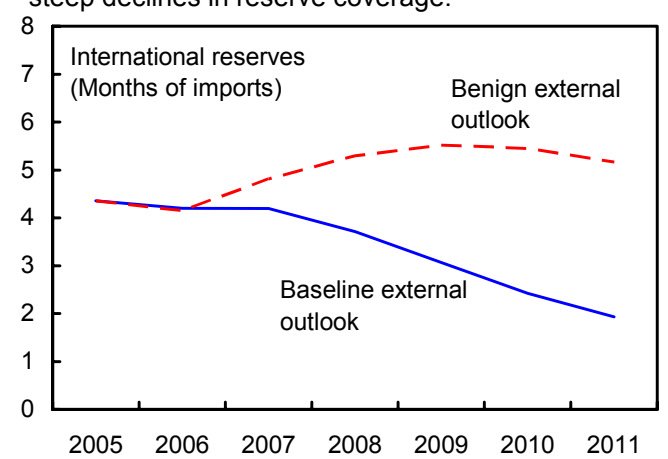

Recommended Policies 3/

A more flexible exchange rate could help insulate the economy from external headwinds...

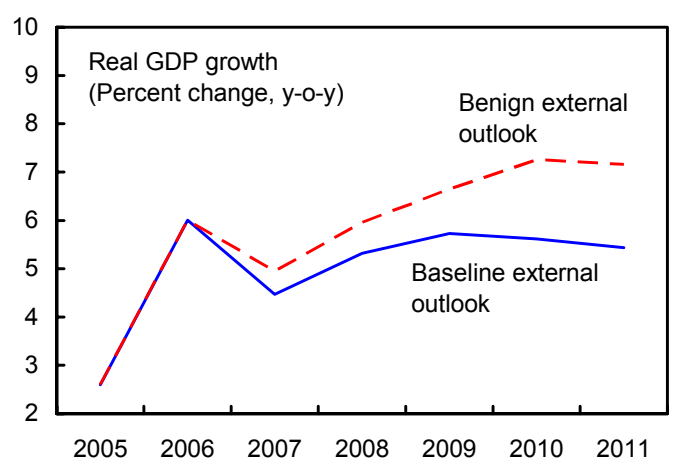

...and allow the NBU to bring inflation down even with a benign external environment.

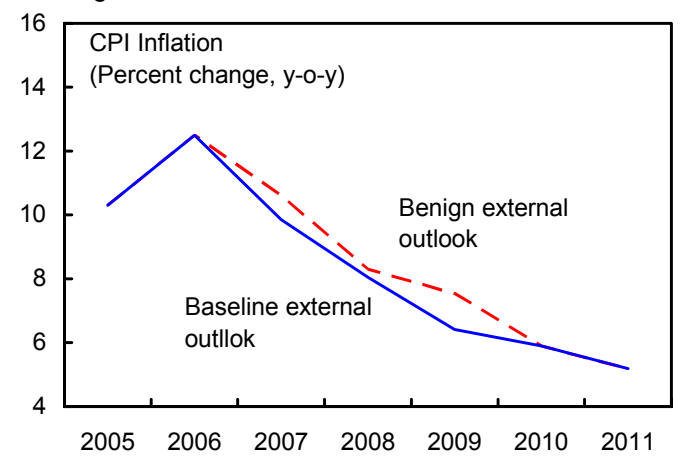

Exchange rate flexibility could allow the authorities to keep reserves in a comfortable range.

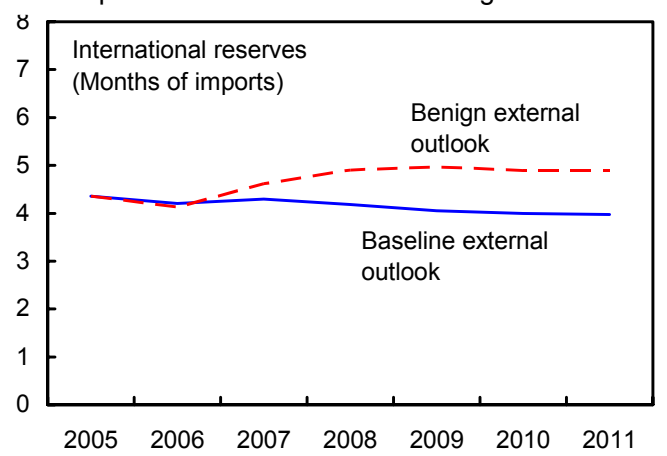

Sources: Ukrainian authorities; and staff estimates.

1/ Both baseline and benign external scenarios assume natural gas prices converge to Western European levels (adjusted for transit) by 2010 . The benign external scenario assumes substantially higher steel prices through 2011, faster export volume growth, and higher FDI relative to the baseline external scenario.

$2 /$ The authorities' policies are assumed to include (i) a fixed exchange rate through 2009 , followed by a gradually widening exchange rate corridor; (ii) full pass-through of rising energy import prices to industry, but zero pass-through to consumers; and (iii) annual real wage growth of 5 percent.

3/ Staff recommended policies include: (i) full pass-through of energy import prices; (ii) a more flexible exchange rate starting in 2007; and (iii) minimum wage growth in line with the CPI excluding energy. 
account deficits could be contained at some 5 percent of GDP, broadly in line with the economy's savings constraints and investment needs (Table 9, Figure 11). Ukraine's sharply increased need for gross external financing would also prove manageable. There would be some temporary increase in CPI inflation owing to continued energy-price pass-through to consumers, pushing inflation to $10 \frac{1}{2}$ percent by end-2007. However, the recommended policies would help contain second-round impacts, and lower inflation to about 5 percent in the medium term. Growth could moderate to $4 \frac{1}{2}$ percent in 2007 , but return to some $5 \frac{1}{2}$ percent in the medium term. Under the benign external outlook and recommended policies, there would still be near-term adverse macroeconomic effects from the energy-price shock, including higher inflation and lower growth. However, strong FDI would lift mediumterm growth and exports, while a more flexible exchange rate regime would allow the NBU to counteract the inflationary impact of balance-of-payments inflows.

\section{B. What Monetary Framework for Ukraine?}

20. A more flexible exchange rate regime should be the centerpiece of a more robust overall policy framework. ${ }^{6}$ Ukraine's economy is vulnerable to large terms-of-trade fluctuations and increasingly also to shifts in capital flows. Thus, maintaining the peg would require that fiscal and incomes policies would be able and willing to shoulder the potentially large burden of maintaining external balance if shocks occur-an unlikely prospect, in staff's view. Moreover, the peg would also likely continue to have difficulties delivering low and stable inflation and encourage excessive risk-taking by unhedged borrowers. ${ }^{7}$
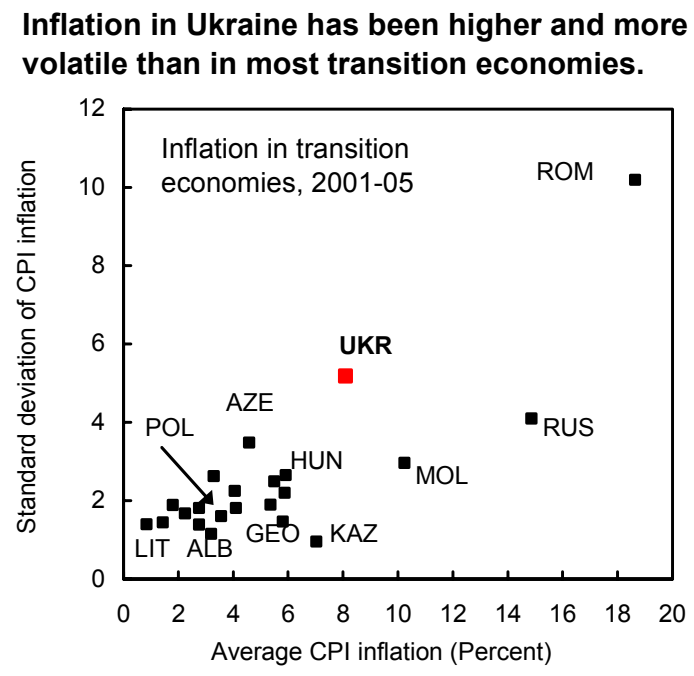

Sources: IMF International Financial Statistics; and staff estimates.

\section{The NBU agreed in principle with the potential benefits of a more flexible exchange-rate regime, but felt that these were still currently outweighed by risks.} Exchange-rate movements, in either direction, could undermine the hard-earned trust in the currency, evoke distributional conflicts, and, in case of depreciations, have adverse balancesheet effects. Also, monetary policy could not yet be operated effectively given underdeveloped financial markets. Thus, while preparations toward inflation targeting would be continued, no significant fluctuations in the nominal exchange rate were foreseen for the next few years.

\footnotetext{
${ }^{6}$ See Selected Issues Chapter II "Monetary and Exchange Rate Policy Framework-Where to Go from Here?"

${ }^{7}$ See Selected Issues Chapter III "Financial Dollarization in Ukraine- - Roots and Risks."
} 
22. While taking note of the authorities' concerns regarding adverse balance-sheet effects, staff suggested that the timing for shifting to greater flexibility seemed right. Political uncertainties have receded, the exchange rate is significantly better aligned with fundamentals, and fiscal and income policies are set to tighten over the medium term, providing a supportive environment. Moreover, conditions in international markets are benign, while the level of international reserves should provide adequate insurance against portfolio shifts. As regards adverse balance-sheet effects, staff's analysis (see Box 3 below) suggests that a large, sudden depreciation could indeed test the banking sector's resilience. While this concern argued for a measured shift to a more flexible exchange rate, it also seemed to caution against shifting only very gradually given the scope for significant overvaluation building up under scenarios that combine a maintained peg and an adverse external environment. Therefore, for 2007, the exchange rate should be allowed to move within the Hrv/US\$4.95-5.25 corridor announced in the NBU's 2007 Monetary Policy Guidelines, and the exchange-rate corridor should be gradually widened over time

\section{Because events might overtake a very gradual transition strategy, swifter action in several other areas seemed called for:}

- $\quad$ The NBU should introduce a short-term policy rate for monetary operations, and proceed with technical preparations for inflation targeting, on which much headway has already been made (Table 10).

- $\quad$ The government should provide the NBU with a clearer mandate to pursue price stability as its primary objective. Thus, the signing of a joint Memorandum of Understanding between the NBU and the government could send a useful signal to the public that the government backs a shift to inflation targeting. However, ultimately the NBU Law should be amended in that direction.

- $\quad$ And the government should also more actively support financial-market development, including by eliminating the foreign-exchange transaction tax as well as relying more on domestic borrowing and issuing benchmark securities. The authorities were receptive, but cited fiscal-cost considerations and shallow domestic markets as key reasons to phase out the foreign-exchange transactions tax only gradually and to continue relying mainly on external borrowing.

24. Views differed on how proactive monetary policy should be in containing underlying inflation pressures. The NBU and staff agreed that the government's inflation objective of $7 \frac{1}{2}$ percent for end-2007, which implies an estimated disinflation of $4 \frac{1}{2}$ percentage points relative to end-2006, could not be reached if energy price hikes were passed through to consumers. In that event, there was agreement that first-round effects should be accommodated. The main issue was, however, what monetary stance would be appropriate for containing pressures on underlying inflation, i.e. CPI excluding energy. The NBU viewed current monetary conditions as appropriate and envisaged broad money growth 
in the range of 28-33 percent for 2007. Staff, noting substantial excess liquidity in the banking system and highly negative short-term interest rates, viewed current monetary conditions as too loose and argued for tighter liquidity conditions to slow broad money growth significantly below the range envisaged by the NBU.

\section{What Should Be Done to Contain Banking-Sector Vulnerabilities?}

\section{In view of the uncertain external outlook, there is some urgency to upgrade} banks' capacity to deal with risks. For example, in a risk scenario where rising macroeconomic imbalances caused large capital outflows, an overshooting exchange rate could severely impact borrowers' repayment ability. Stress tests (Box 3) based on a number of sensitive assumptions suggest that the cushions in some banks might not be sufficient to withstand such a shock. Indeed, high credit concentration in some banks could accentuate the shock, and the heavy reliance on collateral, which may prove to be overvalued and difficult to repossess, could also backfire. Rating agencies are also concerned about the vulnerability of the banking sector and continue to rate many banks at far-below investment grade.

\section{The authorities shared these concerns and have already taken measures to limit} risks. Drawing on the lessons from the country's past financial crises - including a nearliquidity crisis in late-2004 during the Orange Revolution - the NBU has started to enhance its own risk-management plans and tightened various banking regulations. In particular, it has strengthened quality standards for bank capital, raised minimum-capital requirements, differentiated required reserve ratios by currency, and introduced higher provisioning ratios for unhedged borrowers in foreign exchange. Staff welcomed plans to raise provisioning requirements further and apply higher capital-adequacy risk weights for loans in foreign exchange, and recent legal changes that require the transformation of banks into open jointstock companies are a positive signal for banking-sector transparency.

27. However, additional measures would be warranted. In the short term, the public's awareness of exchange-rate risks should be raised by information campaigns. Banks' risk management practices should be strengthened by issuing NBU guidelines on foreignexchange risk management and mortgage lending, setting upper limits on debt service-toincome and loan-to-value ratios for mortgage loans, and enforcing stricter collateral valuation rules. Over the medium term, the authorities should continue moving toward more risk-based supervision, where bank-specific capital requirements would be better matched with bankspecific risks. Pending these developments, the NBU should raise the minimum capitaladequacy ratio from 10 to a more prudent 12 percent. The NBU broadly agreed with most proposed steps, but regarded raising the capital-adequacy ratio as unnecessary given recent steps to tighten the definition of capital, particularly by limiting the amount of revaluation gains. Finally, there was agreement that adopting the amendments to the NBU Law allowing the authorities to suspend early deposit withdrawals in times of crisis would respond to heightened liquidity risks. 


\section{Box 3. Foreign Currency-Induced Credit Risk: A Sensitivity Analysis}

While the banking system seems well-positioned to deal with orderly exchange-rate fluctuations, it would be vulnerable to a sharp hryvnia depreciation. A key assumption for testing banks' resilience is the relationship between exchange-rate movements and nonperforming loans. Broadly in line with international experience for dollarized economies, the analysis assumes that a 20 percent depreciation of the hryvnia would increase nonperforming loans by 30 percent, requiring additional provisions of 15 percent of foreigncurrency loans. The chart below shows that such a shock would push the banking sector's capital-to-asset ratio from a current 12 to 6.5 percent ( 13 of the largest 15 banks would fall below that level). A 5 percent depreciation, on the other hand, would leave the capital-toasset ratio close to 10 percent.

Ukraine: Sensitivity Analysis for Currency-Induced Credit Risk, June 2006

The chart shows by how much a given hryvnia depreciation (horizontal axis) would reduce the banking sector's capitalto-asset ratio (LHS) and how much extra capital would be needed to keep the ratio at 10 percent (RHS).

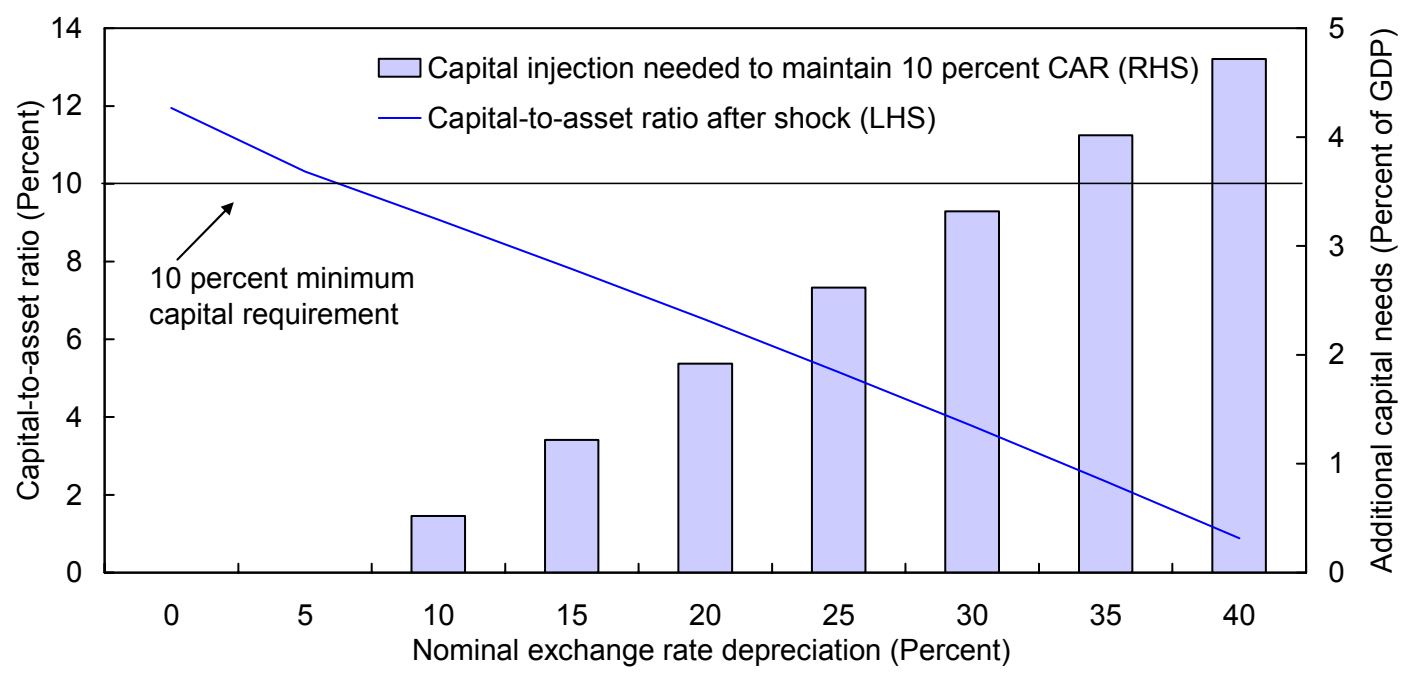

Sources: National Bank of Ukraine; and staff calculations.

\section{Is Ukraine's Fiscal Framework Adequate?}

28. Two elements of the authorities' fiscal framework should serve them well:

- The authorities intend to target a fiscal deficit of about $2 \frac{1}{2}$ percent of GDP over the medium term. Achieving such a target would stabilize the explicit public debt at 10-15 percent of GDP, providing a significant cushion against realization of contingent fiscal liabilities. Even so, speeding up repayment of the contingent large lost-savings liability could have undesirable macroeconomic and fiscal effects, and any proposal to this end would need to be carefully designed. Moreover, if the 
exchange-rate peg were to remain in place and adverse external conditions materialized, the framework's fiscal-deficit target could prove too loose for maintaining external and internal balance.

- The authorities intend to reduce recurrent spending and taxes over the medium term. They saw the intended reduction in the size of government as a stimulus to growth. In fact, incomes policy restraint-the increase in the public wage bill in 2007 would be limited to just $6 \frac{1}{2}$ percent — could also assist monetary policy in the transition to a more flexible exchange rate: by improving competitiveness, it could reduce pressure for abrupt exchange-rate movements, and thus help mitigate balancesheet risks. To assist with re-orienting the structure of spending and designing sustainable tax cuts, staff noted the need to improve the medium-term budget framework.

29. However, the management of risks arising from the still large state-enterprise sector was seen in need of considerable improvement. This sector is loosely monitored, a significant drain on the budget, and a source of potentially large quasi-fiscal activity. In particular, rising energy-import prices could have significant adverse effects on stateenterprise balance sheets, making improving governance even more urgent. ${ }^{8}$ The authorities noted that they had allowed pass-trough of energy prices in 2006 and indicated that they were attempting to exert greater control over enterprises' financial plans.

\section{Fiscal policy plans for 2007, as adopted by parliament in early-December 2006,} raise several issues and risks:

- $\quad$ Achieving the authorities' 2007 fiscal target of just below 3 percent of GDP could prove quite challenging, notwithstanding the authorities' proven record of meeting ambitious revenue targets. Under staff's baseline, revenues would be lower, and some $1 \frac{1}{4}$ percent of GDP of measures might be needed to compensate.

- $\quad$ Measures, if needed, should focus on reductions in recurrent spending: the adopted 2007 budget projected nominal recurrent spending to rise by some 15 percent, leaving the recurrent spending ratio well above 40 percent of GDP. This outcome is at odds with the government's fiscal framework intentions.

- The authorities' intention to pass through higher energy-import prices to producers but not to consumers in 2007 could have a quasi-fiscal cost of about $1 / 2$ percent of GDP, even accounting for the availability of cheaper domestically-produced gas. The authorities argued that a freeze on pass-through to consumers was warranted in light of the large 2006 price hikes, worries about declining payment discipline, and the

\footnotetext{
${ }^{8}$ See Selected Issues Chapter I “The Macroeconomic and Fiscal Impacts of Energy Price Shocks in Ukraine.”
} 
additional fiscal cost as more lower-income households become eligible for cost subsidies. However, the impact of further price increases could be cushioned by the large recent real wage and pension increases as well as an already existing differentiated tariff scheme to protect small users. Staff noted that to help dilute the influence of political imperatives on setting domestic energy prices, more independence should be given to the energy regulator to set prices in line with cost.

\section{E. How Can Ukraine Catch Up with its More Advanced Transition Peers?}

\section{Raising Ukraine's lagging living standards is at the center of the authorities'} policy agenda. Cross-country analysis suggests that Ukraine's relatively low per capita income reflects highly inefficient use of available real and human resources (Figure 12). ${ }^{9}$ Ukraine's bleak longer-term demographics add urgency to accelerating structural reforms. The United Nations projects Ukraine's population to shrink by almost half by 2050 , and the old-age dependency ratio to more than double. Failure to boost per capita income over the medium term could expose Ukraine to a vicious circle, with outward migration of skilled labor undermining public finances and sapping political support for reforms, which in turn could reinforce emigration pressures.
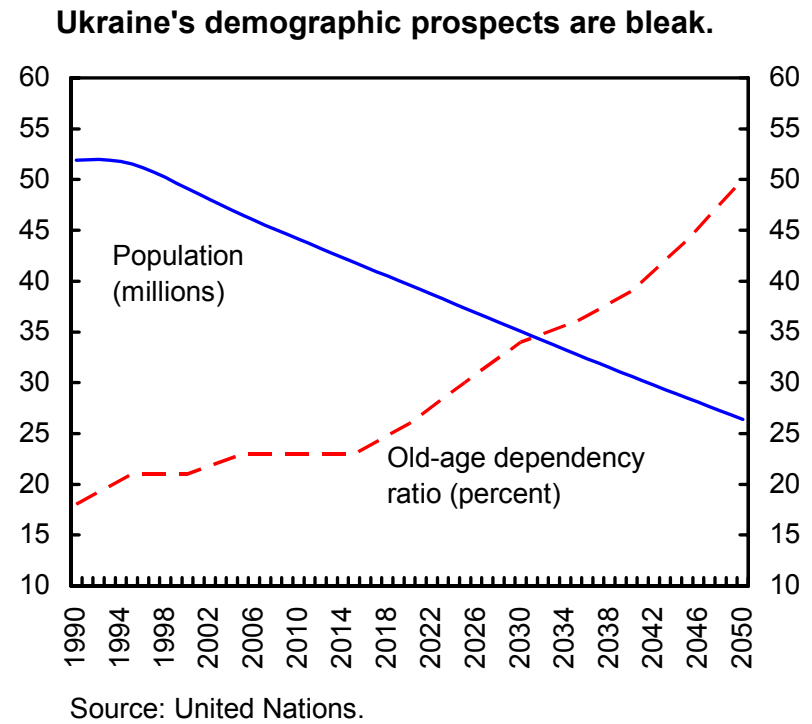

32. The authorities saw shifts in the structure of the budget and in the tax regime as key to unlocking higher investment and growth. The savings from tight incomes and transfer policies would fund higher sectoral subsidies, significantly higher public investment, and tax relief. Initially, tax relief would be selective, coming in the form of restored tax breaks in FEZs to help diversify Ukraine's manufacturing base away from steel and chemicals; in the medium term, corporate and VAT rates would be reduced. These measures, in combination with other structural policies and the authorities' benign medium-term external outlook, were projected to ratchet up both investment- and savings-GDP ratios, consistent with large future current-account surpluses.

33. Fiscal policy could be a catalyst for investment and growth, but the authorities' specific policies presented problems and a key challenge:

\footnotetext{
${ }^{9}$ Tiffin, 2006, “Ukraine: The Cost of Weak Institutions,” IMF Working Paper No. 06/167.
} 


\section{Figure 12. Ukraine: Potential Output and Structural Reforms}

Ukraine's actual output is far below potential, even when compared with other transition economies,...

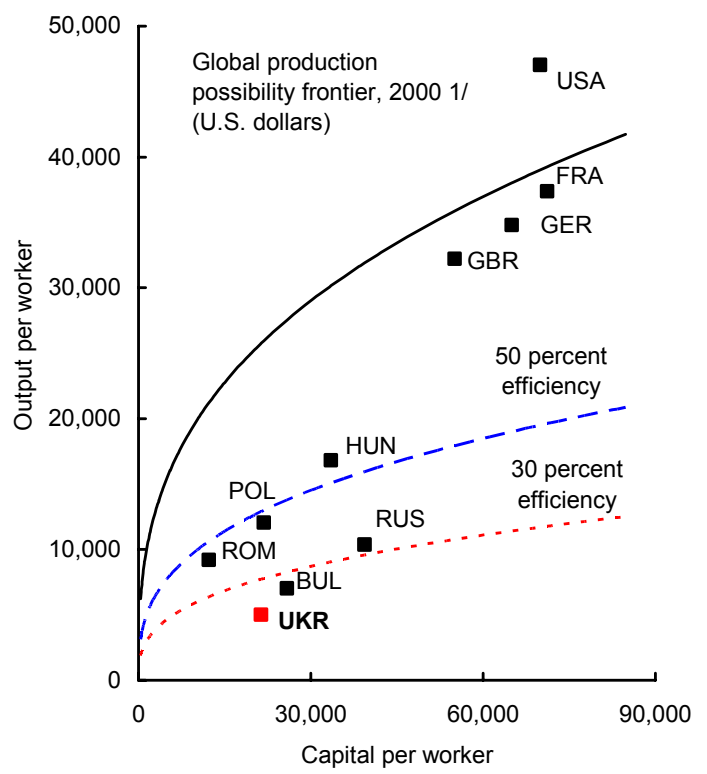

Ukraine's business climate remains very difficult...

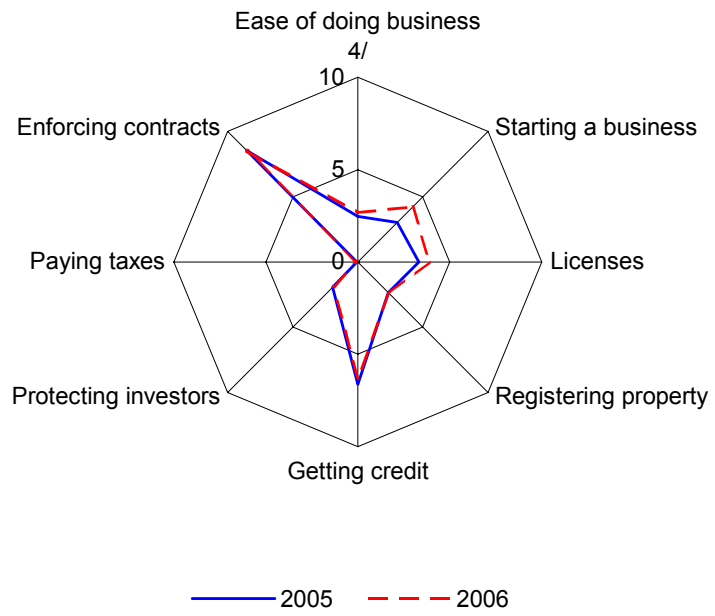

...reflecting Ukraine's weak marketsupporting institutions.

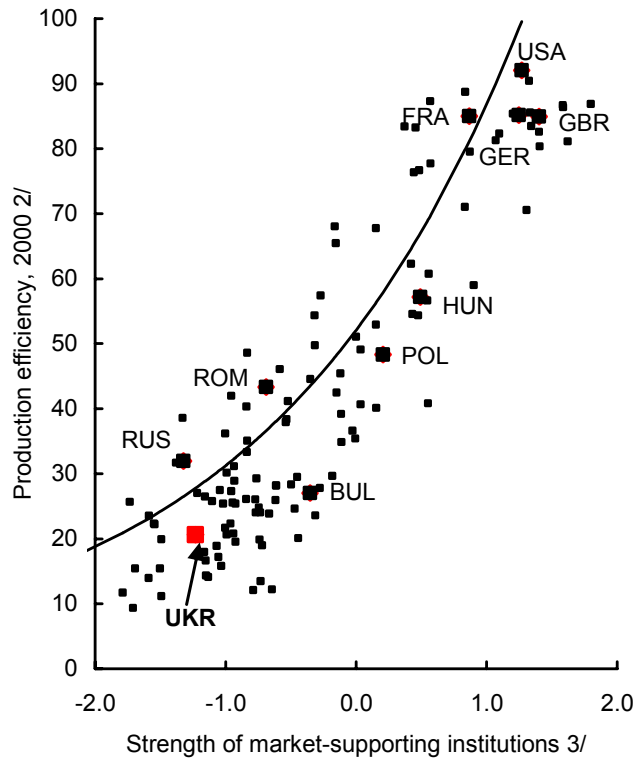

... even though perceptions of corruption have recently improved.

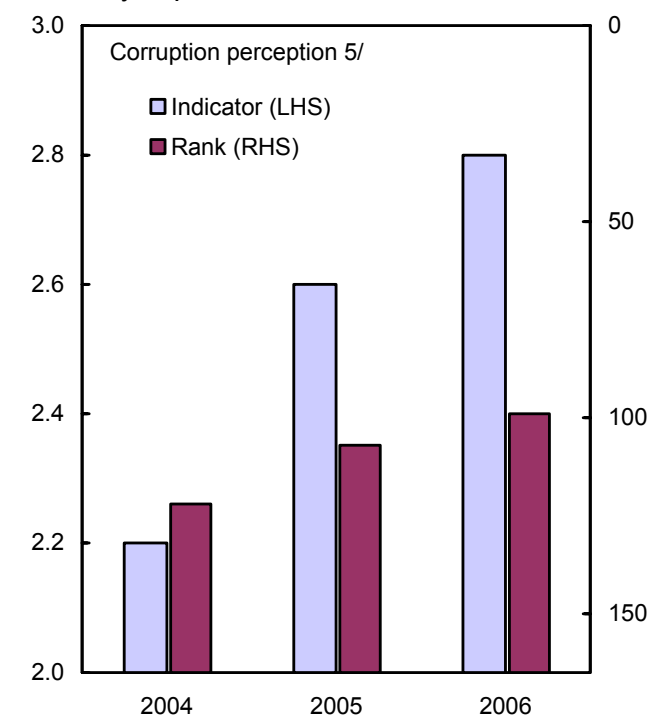

Sources: World Bank Governance Database; and staff estimates.

$1 /$ The frontier represents the implicit output level that could be obtained if a country were to employ all its resources efficiently, using global best practices.

2/ Measures how closely (in percent) a country operates to the global production-possibility frontier.

$3 /$ Measured using the principal component of indices compiled from the World Bank Governance Database (ranging from -2.5 to +2.5 ), comprising rule of law, political stability, control of corruption, government effectiveness, and regulatory quality.

4/ World Bank Doing Business indicators. "Ease of doing business" summarizes the other categories. Ukraine's rank among 163 countries was transformed here into an index, with 10 as the best and 0 as the lowest value.

5/ Transparency International's Corruption Perception Index. The index ranges from 0 to 10, with 10 indicating the lowest degree of perceived corruption. Ranking of the assessed countries is from low to high in perceived corruption. 
- A new round of sectoral subsidies and selective tax relief would inhibit the flow of resources to more productive uses, even while raising fiscal-revenue risks. Thus, new tax preferences for FEZs should be avoided, and if this advice could not be heeded, the zones should be subject to best international practices, with limited indirect tax relief and measures to contain fraud.

- $\quad$ Sustainably reducing recurrent expenditures would require not only curtailing the high public-wage bill but also tackling the large imbalances in the pension fund. Indeed, these would only grow worse over time as Ukraine's demographic situation deteriorated. To this end, a reform plan should focus on broadening the social contribution base, raising retirement ages, tightening pension eligibility, and building up a funded second-pillar system, which could also provide a boost to financialmarket development. ${ }^{10}$

\section{Improving the investment climate would also be indispensable for unlocking} catch-up growth. Ukraine's large efficiency gap in using available resources seemed well explained by the weakness of its market-supporting institutions_-proxied by variables capturing security of property rights, corruption, and regulatory quality (Figure 12). In fact, the World Bank's Doing Business survey continues to rank Ukraine's investment climate near the bottom among transition economies. This suggested that private investors' difficulties to appropriate the returns on their investments constituted a binding bottleneck on Ukraine's growth. Moreover, lagging financial-market development was simply another symptom of weak market-supporting institutions, as, for example, weak corporate governance and uncertain minority-shareholder rights crippled stock markets.

\section{The new government's program aims at building a functioning market economy, but so far several steps have been} retrograde. Arguably, more progress on structural reforms has been achieved during the last $1 \frac{1}{2}$ years than commonly perceived, as indicated by steadily improved perceptions of corruption and surging FDI inflows, although both improvements started from low bases. Nevertheless, the list of outstanding structural reforms remains long and daunting, including further pruning of Ukraine's regulatory jungle, reactivation of

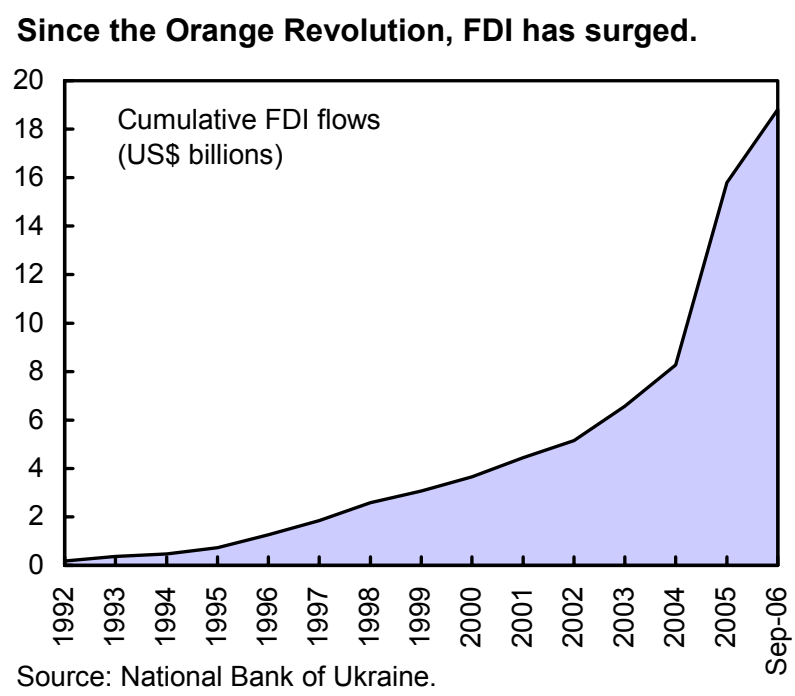

\footnotetext{
${ }^{10}$ For a detailed pension reform proposal, see World Bank, 2006, "Creating Fiscal Space for Growth: A Public Finance Review."
} 
a transparent privatization process, and energy sector reforms (Table 1). The new government has pledged to act swiftly and comprehensively to advance structural reforms. However, recent measures such as the introduction of restrictions on grain export and renewed withholding of VAT refunds were steps away from building a functioning market economy. Staff advocated that these decisions should be reversed. In the case of VAT refunds, staff recalled long-standing Fund advice to address the underlying fraud issue through fundamental reforms of the tax administration and not ad-hoc measures.

36. The authorities want to leverage international integration to raise growth. They noted that the necessary legal steps for WTO accession would likely be in place by year-end. WTO accession would also open the way for deeper integration, including free trade, with the EU. Staff welcomed the authorities' ambitious WTO accession commitments, but complementary behind-the-border reforms would be crucial to reap the growth benefits from trade liberalization. At the same time, the authorities' approach to capital-account liberalization remains cautious, which staff saw as appropriate, not least in view of concerns about banking-sector stability and the unsettled status of the monetary framework. In the short term, the main planned liberalization measure is to extend the repatriation requirement for export proceeds from 90 to 180 days.

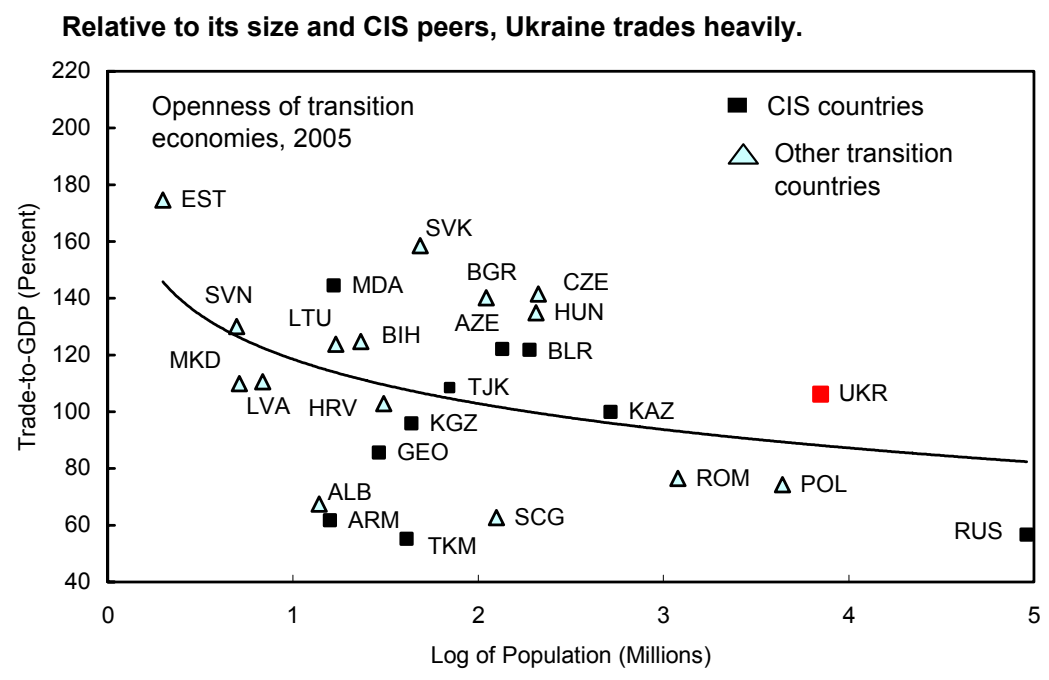

Sources: IMF World Economic Outlook; and staff estimates.

\section{Staff Appraisal}

\section{Despite turbulent politics, the economy has proven resilient and has become}

better balanced. Growth has returned to near trend, and CPI inflation moderated through most of 2006. Moreover, after several years of large surpluses, the current account is close to balance, foreign-exchange reserves are at a comfortable level, and the hryvnia's previously large margin of undervaluation has narrowed considerably. The authorities have also shown their mettle in achieving fiscal-deficit targets, and explicit public debt has fallen to low levels.

\section{However, surging prices for energy have rekindled short-term macroeconomic} tensions, and external prospects are uncertain. Higher prices for energy imports amount to a negative productivity shock. To their credit, the authorities passed through energy-import 
price hikes in 2006, notwithstanding the short-run inflationary impact. Looking ahead, prices for imported natural gas seem set to continue to approach Western European levels. At the same time, there are uncertainties related to prospects for steel prices and capital flows.

39. Ukraine also needs to address three longer-standing challenges. First, and despite measurable progress over the last $1 \frac{1}{2}$ years, the country lags in adopting market-friendly institutions, and, as a consequence, falls far short of reaching its potential income level given available human and real resources. Second, the present monetary framework, which is anchored by a de facto peg, is likely to face increasing difficulties in maintaining internal and external balance given Ukraine's volatile macroeconomic environment. Finally, financial dollarization remains high, and a long-lasting credit boom and heavy external borrowing by banks and corporates have created mismatches on banks' and borrowers' balance sheets. This has increased concerns about the banking sector's stability, particularly if large adverse shocks should materialize.

\section{A coordinated package of policies is needed to address Ukraine's short- and} long-term challenges. Allowing continued pass-through of higher energy prices to consumers, introducing a more flexible exchange rate, tightening income policies, and restraining monetary and fiscal policies would be the best policy option for maintaining external and internal balance, regardless of the size and direction of external shocks. At the same time, the banking sector's ability to cope with adverse shocks needs to be strengthened. Finally, accelerating structural reforms and reversing the recent shift to a consumptionoriented budget structure should boost underlying growth.

41. Against this backdrop, the authorities' fiscal framework intentions are welcome, but budget plans for 2007 raise concerns. The new government's intentions to target a general government deficit close to $2 \frac{1}{2}$ percent of GDP, while reversing the recent surge in recurrent spending over the medium term, fit policy requirements well. But the adopted 2007 budget represents a lost opportunity as regards containing recurrent spending, and it also appears to be based on overly optimistic macroeconomic assumptions. Moreover, specific undertakings to hike sectoral subsidies and the intention to reopen, albeit partially, tax breaks in the free economic zones are not appropriate, particularly as they may turn out to be only first steps down a slippery slope. The authorities should continue allowing full pass-through of energy prices in 2007 and beyond to help raise Ukraine's low energy efficiency and avoid quasi-fiscal deficits in the energy sector. Social groups vulnerable to energy price increases can and should be protected using targeted support.

\section{From several perspectives, a more flexible exchange rate would be better suited}

to Ukraine's evolving challenges. It would facilitate external price adjustment and help improve control of inflation, regardless of whether external upside or downside risks materialize. And, by withdrawing the present de facto exchange rate guarantee, it would help stem financial dollarization, while providing scope for developing hedging markets for foreign-exchange risks. Thus, preparatory steps taken by the NBU toward introducing 
inflation targeting are welcome. However, as a matter of insuring against risks, the authorities should accelerate the transition to inflation targeting beyond the presently envisaged very gradual pace. And the government should support the transition by flanking measures, including by eliminating the foreign-exchange transactions tax and by pursuing a deficit-financing strategy more focused on developing domestic securities markets.

\section{Rising balance-sheet vulnerabilities, particularly related to foreign-exchange} lending, call for more proactive regulation and supervision of the banking sector. Given an unabated domestic credit boom, increasingly driven by household lending, and heavy external borrowing, the ability of many banks to cope with rising risks may be called into question. In this context, the NBU's recent steps to improve regulatory and supervisory safeguards in the banking sector are welcome. However, over the medium term, there is a need to better match bank-specific capital requirements and risk management with bankspecific risks. An increase in the minimum capital-adequacy ratio from 10 to 12 percent would therefore provide an additional safeguard for banking stability until risk-management practices improve. Finally, the envisaged update of the FSAP in 2007 would provide a welcome and timely opportunity to extend and deepen the diagnosis of financial sector vulnerabilities.

44. Ukraine's difficult investment climate and underdeveloped financial markets are key binding constraints on Ukraine's economic development. Priority steps should include WTO accession, adopting legislation to strengthen investor rights and removing legal inconsistencies between laws, reactivating a transparent and fair privatization process, and reforming the energy sector to boost efficiency and transparency. Retrograde steps, such as the recent introduction of restrictions on grain exports, should be reversed.

45. Official statistics are broadly adequate for surveillance, but policy makers need better data to gauge external and financial vulnerabilities. Better measurement is vital for policy focus. It is therefore important to compile and disseminate better-quality data on trade prices, the state-owned enterprise sector, and sectoral financial flows and stocks.

46. It is recommended that the next consultation occur on the standard 12-month cycle. 
Table 1. Ukraine: Structural Reforms: Progress Report

\begin{tabular}{|c|c|c|}
\hline Areas & Main Achievements since 2005 & Key Outstanding Reforms 1/ \\
\hline $\begin{array}{l}\text { Investment } \\
\text { climate }\end{array}$ & $\begin{array}{l}\text { - Leveled playing field by eliminating tax preferences, including } \\
\text { in Free Economic Zones. } \\
\text { - Reviewed over 9,000 business regulations and repealed and } \\
\text { amended nearly 5,000. } \\
\text { - Conducted a fully transparent re-privatization auction of a } \\
\text { large steel mill (Kryvorizhstal). }\end{array}$ & $\begin{array}{l}\text { - Abolish anachronistic Economic Code and improve the market-oriented } \\
\text { - } \text { Aivil Code. } \\
\text { - Adopt Joint Stock Company Law and Limited Liability Company Law. } \\
\text { - Adopt International Accounting Standards for large corporates. } \\
\text { - } \text { Lift the moratorium for the resale of agricultural land; remove current } \\
\text { restrictions in Land Code on non-agricultural land ownership. } \\
\text { - Implement reform of the court system to ensure independence and } \\
\text { impartiality. }\end{array}$ \\
\hline Trade policy & $\begin{array}{l}\text { - Received market economy status from the EU and the United } \\
\text { States. } \\
\text { - Slashed average import tariffs from } 7.7 \text { percent to } 5.1 \text { percent, } \\
\text { significantly exceeding WTO requirements. }\end{array}$ & $\begin{array}{l}\text { - Adopt remaining legislation for WTO accession. } \\
\text { - Adopt Customs Code in line with WTO agreements and EU legislation. }\end{array}$ \\
\hline $\begin{array}{l}\text { Energy } \\
\text { sector }\end{array}$ & $\begin{array}{l}\text { - Adopted legislation to mutually offset and restructure debts of } \\
\text { the energy sector. } \\
\text { - Adopted cash payments for gas transits through Ukraine } \\
\text { (rather than payments in kind). }\end{array}$ & $\begin{array}{l}\text { - Implement government strategy to improve energy efficiency. } \\
\text { - Implement Ukraine's coal mine restructuring plan. } \\
\text { - Enhance independence of National Electricity Regulatory Commission. }\end{array}$ \\
\hline $\begin{array}{l}\text { Fiscal- } \\
\text { structural } \\
\text { reforms }\end{array}$ & & $\begin{array}{l}\text { - Implement comprehensive strategic reform for State Tax Administration. } \\
\text { - Strengthen the large taxpayer office under the State Tax Administration. } \\
\text { - Implement a medium-term budget framework. } \\
\text { - Bring public procurement legislation in line with EU legislation. } \\
\text { - Set up a monitoring and oversight system for financial risks in state- } \\
\text { owned enterprises. } \\
\text { - Reform the system of unfunded social mandates and replace it with a } \\
\text { targeted social protection system. }\end{array}$ \\
\hline
\end{tabular}

1/ Measures listed above have been drawn from the Ukraine-EU Action Plan, and World Bank, OECD, and Fund recommendations. 
Table 2. Ukraine: Selected Economic and Social Indicators, 2003-07

\begin{tabular}{|c|c|c|c|c|c|c|}
\hline & \multirow[t]{2}{*}{2003} & \multirow[t]{2}{*}{2004} & \multirow[t]{2}{*}{2005} & \multirow{2}{*}{$\begin{array}{r}2006 \\
\text { Proj. }\end{array}$} & \multicolumn{2}{|c|}{2007} \\
\hline & & & & & $\begin{array}{l}\text { Authorities' } \\
\text { Policies 1/ }\end{array}$ & $\begin{array}{c}\text { Recommended } \\
\text { Policies 2/ }\end{array}$ \\
\hline \multicolumn{7}{|l|}{ Real economy (percent change unless indicated otherwise) } \\
\hline Nominal GDP (billions of hryvnias) & 267.3 & 345.1 & 424.7 & 505.4 & 565.4 & 573.7 \\
\hline Real GDP & 9.6 & 12.1 & 2.6 & 6.0 & 4.3 & 4.5 \\
\hline Domestic demand & 11.4 & 12.3 & 12.2 & 9.6 & 4.7 & 4.0 \\
\hline Unemployment rate (ILO definition; percent) & 9.1 & 8.6 & 7.8 & 7.5 & 7.5 & 7.5 \\
\hline Consumer prices (period average) & 5.2 & 9.0 & 13.5 & 9.1 & 12.9 & 13.6 \\
\hline Consumer prices (end of period) & 8.2 & 12.3 & 10.3 & 12.5 & 8.2 & 10.6 \\
\hline Consumer prices excluding energy (end of period) & 7.7 & 11.2 & 9.4 & 8.3 & 8.3 & 8.3 \\
\hline Nominal monthly wages (average) & 23.0 & 27.7 & 36.5 & 23.3 & 14.9 & 14.3 \\
\hline Real monthly wages (average) & 16.9 & 17.1 & 20.3 & 13.0 & 1.8 & 0.6 \\
\hline \multicolumn{7}{|l|}{ Public finance (percent of GDP) } \\
\hline Cash balance & -0.9 & -4.4 & -2.4 & -2.4 & -4.1 & -2.5 \\
\hline Expenditure (cash basis) & 36.8 & 39.5 & 43.6 & 45.4 & 47.3 & 45.3 \\
\hline Primary balance (cash basis) & 0.1 & -3.5 & -1.6 & -1.7 & -3.2 & -1.5 \\
\hline Commitments balance $4 /$ & -1.2 & -4.1 & -1.9 & -2.7 & -4.0 & -2.4 \\
\hline Privatization proceeds & 1.1 & 3.1 & 5.1 & 0.1 & 2.0 & 1.9 \\
\hline Net domestic financing & -1.2 & -0.1 & -3.4 & 1.7 & 0.0 & 0.4 \\
\hline Net external financing $3 /$ & 1.0 & 1.4 & 0.6 & 0.6 & 0.9 & 0.1 \\
\hline Public debt $5 /$ & 30.6 & 25.5 & 19.4 & 16.8 & 16.2 & 14.6 \\
\hline Of which: external debt & 21.6 & 19.2 & 14.7 & 12.2 & 11.3 & 10.6 \\
\hline Of which: external debt, incl. hryvnia debt held by non-residents & 21.6 & 19.3 & 16.2 & 12.9 & 12.0 & 11.4 \\
\hline \multicolumn{7}{|l|}{ Money and credit (end of period, percent change) } \\
\hline Base money & 30.1 & 34.1 & 53.9 & 18.8 & 17.2 & 12.0 \\
\hline Broad money & 46.5 & 32.3 & 54.4 & 33.7 & 30.5 & 22.1 \\
\hline Credit to nongovernment & 63.4 & 31.2 & 61.5 & 64.0 & 35.3 & 24.3 \\
\hline Velocity $6 /$ & 2.81 & 2.75 & 2.19 & 1.95 & 1.67 & 1.81 \\
\hline \multicolumn{7}{|l|}{ Balance of payments (percent of GDP) } \\
\hline Current account balance & 5.8 & 10.5 & 3.1 & -1.0 & -3.9 & -3.1 \\
\hline Foreign direct investment & 2.8 & 2.7 & 9.0 & 3.8 & 4.9 & 4.9 \\
\hline Debt service (in percent of exports of goods and services) 5/ & 6.2 & 4.6 & 4.9 & 5.1 & 4.6 & 4.5 \\
\hline Goods exports (annual volume change in percent) & 14.1 & 18.2 & -5.4 & 6.7 & 7.9 & 10.2 \\
\hline Goods imports (annual volume change in percent) & 30.3 & 13.8 & 14.6 & 11.2 & 6.9 & 6.9 \\
\hline Goods exports & 47.4 & 51.6 & 42.3 & 39.5 & 37.4 & 38.4 \\
\hline Goods imports & 47.9 & 45.8 & 43.6 & 43.8 & 44.8 & 45.0 \\
\hline Share of metals in merchandise exports (percent) & 35.8 & 39.0 & 40.1 & 38.0 & 38.4 & 37.6 \\
\hline Net imports of energy (in billions of U.S. dollars) & 5.1 & 6.0 & 6.1 & 7.9 & 9.5 & 9.4 \\
\hline Goods terms of trade (percent change) & 8.7 & 9.6 & 6.1 & -3.5 & -8.8 & -8.8 \\
\hline Goods and services terms of trade (percent change) & 7.3 & 7.8 & 4.9 & -1.1 & -5.9 & -5.8 \\
\hline \multicolumn{7}{|l|}{ Exchange rate } \\
\hline Exchange rate regime & \multicolumn{3}{|c|}{ de facto peg } & \multicolumn{2}{|c|}{ de facto peg } & managed float \\
\hline Hryvnia per U.S. dollar, end of period & 5.33 & 5.31 & 5.05 & 5.05 & $\ldots$ & . $\quad \ldots$ \\
\hline Hryvnia per U.S. dollar, period average & 5.33 & 5.32 & 5.12 & 5.05 & $\ldots$ & $\ldots$ \\
\hline Real effective rate (percent change) $7 /$ & -5.7 & 2.7 & 17.0 & 8.0 & $\ldots$ & $\ldots$ \\
\hline $\begin{array}{l}\text { Social indicators } \\
\text { Per capita GDP: US } \$ 1,747(2005) \text {; Poverty (percent of population } \\
\text { Life expectancy at birth: } 68.2 \text { years (2002); Infant mortality (per }\end{array}$ & $\begin{array}{l}2001 ; r \\
6.0(20\end{array}$ & eadco & & & (2002) & \\
\hline
\end{tabular}

Sources: Ukrainian authorities; and staff estimates and projections.

1/ Authorities' policies under the baseline external outlook. Policies include: (i) a fixed exchange rate; (ii) full pass-through of rising energy import prices to industry, but zero pass-through to consumers; (iii) a fiscal deficit target of 2.9 percent of GDP; and (iv) growth in the minimum wage of 12.5 percent.

2/ Staff recommended policies under baseline external outlook. These include (i) increased flexibility in the hryvnia/U.S. dollar exchange rate; (ii) full pass-through of rising energy import prices to both industry and consumers; (iii) a fiscal-deficit target of 2.5 percent; (iv) end-period minimum wage growth of 8 percent; and (iv) a monetary policy that aims to reduce core inflation.

3/ From 2003 onward, based on an accounting treatment that excludes offset-based amortization to Russia, which decreases

revenues and increases net external financing (and the budget deficit) by 0.2 percent of GDP relative to previous years.

4/ Cash balance adjusted for the net accumulation of expenditure and VAT refund arrears, as well as for non-cash property income.

5/ Government and government-guaranteed debt and arrears, plus NBU debt. Excludes debt by state-owned enterprises.

6/ Annual GDP divided by end-period broad money (M3).

7/ Period averages; (+) represents real appreciation; based on GDP deflator and INS trade weights (1999-2001). 
Table 3. Ukraine: Medium-Term Balance of Payments, 2003-11 (In millions of U.S. dollars; unless otherwise indicated)

\begin{tabular}{|c|c|c|c|c|c|c|c|c|c|}
\hline & 2003 & 2004 & 2005 & 2006 & 2007 & 2008 & 2009 & 2010 & 2011 \\
\hline & & & & Proj. & \multicolumn{5}{|c|}{ Authorities' policies 1/ } \\
\hline Current account balance & 2,891 & 6,909 & 2,531 & $-1,045$ & $-4,380$ & $-8,222$ & $-11,606$ & $-13,499$ & $-13,790$ \\
\hline Merchandise trade balance & -269 & 3,741 & $-1,135$ & $-4,320$ & $-8,241$ & $-12,651$ & $-16,035$ & $-18,349$ & $-18,807$ \\
\hline Exports & 23,739 & 33,432 & 35,024 & 39,538 & 41,904 & 43,909 & 46,678 & 49,695 & 53,581 \\
\hline Imports & $-24,008$ & $-29,691$ & $-36,159$ & $-43,858$ & $-50,145$ & $-56,560$ & $-62,713$ & $-68,044$ & $-72,388$ \\
\hline Services (net) & 1,557 & 1,237 & 1,806 & 1,683 & 2,338 & 2,919 & 3,120 & 3,914 & 4,525 \\
\hline Receipts 2/ & 5,214 & 7,859 & 9,354 & 11,281 & 12,499 & 13,612 & 14,493 & 15,423 & 16,277 \\
\hline Payments & $-3,657$ & $-6,622$ & $-7,548$ & $-9,598$ & $-10,161$ & $-10,693$ & $-11,373$ & $-11,509$ & $-11,752$ \\
\hline Income (net) & -581 & -645 & -985 & $-1,545$ & $-1,867$ & $-2,171$ & $-2,679$ & $-3,376$ & $-4,165$ \\
\hline Of which: Interest on public debt $3 /$ & -477 & -485 & -659 & -892 & -972 & $-1,077$ & $-1,104$ & $-1,141$ & $-1,217$ \\
\hline Current transfers (net) & 2,184 & 2,576 & 2,845 & 3,136 & 3,390 & 3,681 & 3,988 & 4,312 & 4,656 \\
\hline Financial and capital account & 322 & $-4,332$ & 8,038 & 2,630 & 7,015 & 7,800 & 8,971 & 9,967 & 11,001 \\
\hline Direct investment and capital transfers (net) & 1,394 & 1,718 & 7,468 & 3,793 & 5,516 & 5,658 & 6,119 & 6,414 & 6,967 \\
\hline Portfolio equity investment & $-1,709$ & 859 & 1,437 & 1,242 & 2,144 & 2,394 & 2,644 & 2,894 & 3,044 \\
\hline Bonds and medium and long-term loans (net) & 1,282 & 4,095 & 4,736 & 5,333 & 4,859 & 4,981 & 5,692 & 6,091 & 6,621 \\
\hline Private sector loans & 976 & 1,962 & 3,323 & 5,285 & 3,938 & 4,288 & 4,538 & 4,688 & 4,838 \\
\hline Bonds and loans (official) & 306 & 2,133 & 1,413 & 48 & 921 & 693 & 1,154 & 1,403 & 1,783 \\
\hline Of which: Disbursements & 1,342 & 3,268 & 3,384 & 2,422 & 2,017 & 1,555 & 2,512 & 2,383 & 3,120 \\
\hline Repayments $2 / 3 /$ & $-1,036$ & $-1,135$ & $-1,971$ & $-2,374$ & $-1,096$ & -862 & $-1,358$ & -980 & $-1,337$ \\
\hline Of which: Foreign-currency & $\ldots$ & 1,733 & 162 & 598 & 913 & 425 & 691 & 876 & 1,258 \\
\hline Domestic -currency & $\ldots$ & 400 & 1,251 & -550 & 8 & 268 & 463 & 527 & 525 \\
\hline Short-term capital (net) & -645 & $-11,004$ & $-5,603$ & $-7,738$ & $-5,504$ & $-5,233$ & $-5,485$ & $-5,432$ & $-5,631$ \\
\hline \multicolumn{10}{|l|}{ Of which: Disbursements } \\
\hline Errors and omissions & -953 & -38 & 152 & 152 & 152 & 152 & 152 & 152 & 152 \\
\hline Overall balance & 2,260 & 2,539 & 10,721 & 1,737 & 2,786 & -270 & $-2,484$ & $-3,380$ & $-2,638$ \\
\hline Gross official reserves (- is increase) & $-2,045$ & $-2,226$ & $-10,425$ & $-1,307$ & $-2,372$ & 591 & 2,569 & 3,380 & 2,638 \\
\hline Net use of IMF resources & -215 & -313 & -296 & -430 & -415 & -320 & -85 & 0 & 0 \\
\hline \multicolumn{10}{|l|}{ Memorandum items: } \\
\hline Total external debt (percent of GDP) & 47.6 & 47.3 & 46.6 & 48.3 & 49.4 & 50.3 & 51.3 & 53.8 & 55.6 \\
\hline Current account (percent of GDP) & 5.8 & 10.6 & 3.1 & -1.0 & -3.9 & -6.6 & -8.4 & -9.0 & -8.5 \\
\hline Excluding transfers & 1.4 & 6.7 & -0.4 & -4.2 & -6.9 & -9.6 & -11.2 & -11.9 & -11.4 \\
\hline Debt service ratio (percent of exports of goods and services) 2/3/ & 6.2 & 4.6 & 4.9 & 5.1 & 4.6 & 3.9 & 4.2 & 3.3 & 3.7 \\
\hline Of which: Interest payments & 1.6 & 1.2 & 1.5 & 1.8 & 1.8 & 1.9 & 1.8 & 1.8 & 1.7 \\
\hline Gross international reserves (end of period) & 6,937 & 9,525 & 19,391 & 21,122 & 23,494 & 22,903 & 20,334 & 16,954 & 14,316 \\
\hline In months of next year's imports of goods and services & 2.3 & 2.6 & 4.4 & 4.2 & 4.2 & 3.7 & 3.1 & 2.4 & 1.9 \\
\hline Over next year's official debt service & 3.6 & 3.3 & 5.2 & 8.5 & 10.4 & 9.0 & 9.6 & 6.6 & $\ldots$ \\
\hline Merchandise export values (percent change) & 27.2 & 40.8 & 4.8 & 12.9 & 6.0 & 4.8 & 6.3 & 6.5 & 7.8 \\
\hline Merchandise import values (percent change) & 33.7 & 23.7 & 21.8 & 21.3 & 14.3 & 12.8 & 10.9 & 8.5 & 6.4 \\
\hline Merchandise export volume (percent change) & 14.2 & 18.2 & -5.4 & 6.7 & 7.9 & 5.3 & 6.6 & 7.5 & 8.0 \\
\hline Merchandise import volume (percent change) & 30.4 & 13.8 & 14.6 & 11.2 & 6.9 & 7.2 & 7.5 & 6.9 & 6.8 \\
\hline Terms of trade (percent change) & 8.7 & 9.6 & 6.1 & -3.5 & -8.8 & -5.9 & -3.6 & -2.6 & 0.2 \\
\hline Goods and services terms of trade (percent change) & 7.3 & 7.8 & 4.9 & -1.1 & -5.9 & -4.1 & -2.3 & -1.6 & 0.7 \\
\hline
\end{tabular}

Sources: Ukrainian authorities; and staff estimates and projections.

1/ The authorities' policies are assumed to include: (i) a fixed exchange rate through 2009 , followed by a gradually widening exchange rate corridor;

(ii) full pass-through of rising energy import prices to industry, but zero pass-through to consumers; (iii) a general government fiscal deficit of

2.9 percent of GDP in 2007 and 2.5 percent thereafter; and (iv) annual real wage growth of 5 percent.

$2 /$ Includes lease receipts and offsetting repayments under the Black Sea Fleet debt swap agreement.

3/ Public and publicly-guaranteed debt. 
Table 4. Ukraine: Selected Vulnerability Indicators, 2002-06

\begin{tabular}{|c|c|c|c|c|c|c|}
\hline & 2002 & 2003 & 2004 & 2005 & 2006 & $\begin{array}{r}\text { Latest } \\
\text { observation }\end{array}$ \\
\hline \multicolumn{7}{|l|}{ Financial Market Indicators } \\
\hline Short-term (ST) interest rate (percent) 1/ & 4.5 & 9.3 & 16.3 & 2.9 & 2.3 & $30-N o v-06$ \\
\hline EMBI secondary market spread (bps, end of period) & 691 & 275 & 264 & 184 & 175 & 15-Dec-06 \\
\hline Foreign currency debt rating $2 /$ & B2 & B1 & B1 & B1 & B1 & 15-Dec-06 \\
\hline Exchange rate $\mathrm{NC} / \mathrm{US} \$$ (end of period) & 5.3 & 5.3 & 5.3 & 5.1 & 5.1 & 15-Dec-06 \\
\hline Stock market index (PFTS) & 57.3 & 85.4 & 260.1 & 353.0 & 475.4 & 15-Dec-06 \\
\hline Broad money to gross reserves (percent) & 275.4 & 256.9 & 249.1 & 198.1 & 228.4 & 30-Nov-06 \\
\hline \multicolumn{7}{|l|}{ External Sector } \\
\hline Exchange rate regime & \multicolumn{4}{|c|}{ de facto peg to U.S. dollar } & & \\
\hline Current account balance (percent of GDP) & 7.5 & 5.8 & 10.5 & 3.1 & -1.0 & Proj. \\
\hline Net FDI inflows (percent of GDP) & 1.6 & 2.8 & 2.7 & 9.0 & 3.8 & Proj. \\
\hline Exports (percentage change of US\$ value, GNFS) & 10.7 & 24.0 & 42.6 & 7.5 & 14.5 & Proj. \\
\hline Real effective exchange rate (percent change) $3 /$ & -0.2 & -5.7 & 2.7 & 17.0 & $\ldots$ & Dec-05 \\
\hline Gross international reserves (GIR; US\$ billion) & 4.4 & 6.9 & 9.5 & 19.4 & 21.1 & 30-Nov-06 \\
\hline GIR in percent of ST debt at remaining maturity (RM) & 42.6 & 61.6 & 71.5 & 116.6 & 98.8 & Sep-06 \\
\hline GIR in percent of ST debt at RM and banks' FX deposits & 34.7 & 46.2 & 50.0 & 75.5 & 59.1 & Sep-06 \\
\hline Net international reserves (NIR; US\$ billion) & 2.5 & 5.1 & 7.9 & 18.2 & 20.2 & $30-N o v-06$ \\
\hline Total gross external debt (ED; percent of GDP) & 52.1 & 47.6 & 46.5 & 44.3 & 45.1 & Sep-06 \\
\hline Of which: ST external debt (original maturity, percent of total ED) & 40.4 & 38.5 & 34.7 & 33.8 & 31.8 & Sep-06 \\
\hline ED of domestic private sector (percent of total ED) & 53.8 & 54.5 & 58.7 & 67.1 & 73.6 & Sep-06 \\
\hline ED to foreign official sector (percent of total ED) & 34.6 & 31.5 & 23.1 & 17.3 & 13.3 & Sep-06 \\
\hline Total public external debt (percent of GDP) 4/ & 24.1 & 21.6 & 19.3 & 14.7 & 11.9 & Sep-06 \\
\hline Domestically issued public debt held by non-residents (percent of GDP) & 0.1 & 0.1 & 0.5 & 1.4 & 0.6 & Sep-06 \\
\hline Total gross external debt in percent of exports of GNFS & 94.5 & 82.4 & 76.1 & 84.3 & 91.7 & Sep-06 \\
\hline \multicolumn{7}{|l|}{ Public Sector (PS) 5/ } \\
\hline Overall balance (percent of GDP) & 0.5 & -0.9 & -4.4 & -2.4 & -2.4 & Proj. \\
\hline Primary balance (percent of GDP) & 1.8 & 0.1 & -3.5 & -1.6 & -1.7 & Proj. \\
\hline Debt-stabilizing primary balance (percent of GDP) 4/ & $\cdots$ & $\ldots$ & -5.9 & -4.4 & $\ldots$ & Proj. \\
\hline Gross PS financing requirement (percent of GDP) 6/ & 2.6 & 4.5 & 7.6 & 5.7 & 4.4 & Proj. \\
\hline Public sector gross debt (PSGD, percent of GDP) & 35.7 & 30.6 & 25.5 & 19.4 & 15.7 & Sep-06 \\
\hline Of which: Exposed to rollover risk (percent of total PSGD) & 12.2 & 14.0 & 22.0 & 16.0 & 14.2 & Sep-06 \\
\hline Exposed to exchange rate risk (percent of total PSGD) 6/ & 67.4 & 70.7 & 75.2 & 75.2 & 75.8 & Sep-06 \\
\hline Exposed to interest rate risk (percent of total PSGD) 6/ & 12.2 & 14.0 & 26.0 & 20.0 & 18.5 & Sep-06 \\
\hline Public sector net debt (percent of GDP) & 34.0 & 28.3 & 23.5 & 14.6 & 11.6 & Sep-06 \\
\hline
\end{tabular}

Sources: Ukrainian authorities; and staff estimates and projections.

1/ Overnight interbank rate. Monthly average for December or month of latest observation.

2/ Moody's Investors Service. Fitch and Moody's raised the outlook for Ukraine from stable to positive in October and November 2006, respectively. 3/ Period averages; (+) represents real appreciation; based on GDP deflator and INS trade weights (1999-2001).

4/ Does not include domestically issued public debt held by non-residents.

5/ Public sector covers the consolidated government. It excludes public enterprises. Public debt also includes arrears and debt by the NBU.

6/ Overall balance plus debt amortization. 
Table 5. Ukraine: General Government Finances, 2004-07 1/

\begin{tabular}{|c|c|c|c|c|c|c|c|c|}
\hline & \multirow[t]{2}{*}{2004} & \multirow[t]{2}{*}{2005} & \multicolumn{2}{|c|}{2006} & \multicolumn{4}{|c|}{2007} \\
\hline & & & Budget 2/ & Proj. & $\begin{array}{c}\text { Budget 2/ } \\
\text { First Reading }\end{array}$ & $\begin{array}{c}\text { Budget } 2 / \\
\text { Second Reading }\end{array}$ & $\begin{array}{l}\text { Authorities' } \\
\text { Policies } 3 / \\
\end{array}$ & $\begin{array}{c}\text { Recommended } \\
\text { Policies 4/ }\end{array}$ \\
\hline & \multicolumn{8}{|c|}{ (In millions of hryvnias) } \\
\hline Revenue & 120,944 & 175,236 & 212,931 & 217,518 & 241,830 & 250,124 & 244,266 & 245,966 \\
\hline Tax revenue & 100,821 & 150,301 & 181,805 & 190,122 & 217,257 & 223,186 & 217,374 & 219,075 \\
\hline Personal income tax & 13,213 & 17,325 & 20,791 & 23,090 & 28,789 & 28,789 & 30,609 & 30,456 \\
\hline Enterprise profit tax & 16,162 & 23,464 & 26,260 & 25,151 & 25,033 & 27,113 & 25,905 & 26,287 \\
\hline Payroll tax & 29,042 & 40,071 & 46,385 & 46,865 & 59,616 & 59,616 & 57,462 & 57,115 \\
\hline Property tax & 2,293 & 2,718 & 2,881 & 2,881 & 3,200 & 3,200 & 3,006 & 3,010 \\
\hline VAT & 14,808 & 33,804 & 45,612 & 50,247 & 55,161 & 57,769 & 53,406 & 56,469 \\
\hline Other taxes on goods and services & 14,961 & 18,580 & 23,943 & 22,434 & 23,677 & 24,927 & 24,319 & 22,317 \\
\hline Taxes on international trade & 5,067 & 6,722 & 7,532 & 7,327 & 8,455 & 8,455 & 8,260 & 8,420 \\
\hline Other taxes & 5,276 & 7,617 & 8,402 & 12,126 & 13,325 & 13,316 & 14,407 & 15,001 \\
\hline Nontax, capital revenue, and grants & 20,123 & 24,935 & 31,126 & 27,396 & 24,573 & 26,938 & 26,892 & 26,891 \\
\hline Expenditure & 136,148 & 185,266 & 229,040 & 229,622 & 258,492 & 267,609 & 267,609 & 260,078 \\
\hline Current expenditures & 113,689 & 166,927 & 206,214 & 206,727 & 229,634 & 237,741 & 237,741 & 230,210 \\
\hline Wages & 25,597 & 33,294 & 43,907 & 43,907 & 46,774 & 46,774 & 46,774 & 46,774 \\
\hline Goods and services & 19,646 & 28,442 & 36,476 & 40,241 & 41,047 & 43,993 & 43,993 & 43,993 \\
\hline Subsidies & 7,468 & 9,720 & 14,407 & 14,548 & 17,720 & 22,257 & 22,257 & 17,093 \\
\hline Transfers & 57,768 & 92,159 & 106,956 & 104,695 & 119,404 & 119,404 & 119,404 & 117,036 \\
\hline Pensions 5/6/ & 41,810 & 72,620 & 79,477 & 77,895 & 90,310 & 90,310 & 90,310 & 87,942 \\
\hline Other & 15,958 & 19,539 & 27,479 & 26,800 & 29,094 & 29,094 & 29,094 & 29,094 \\
\hline Interest & 3,210 & 3,312 & 4,469 & 3,336 & 4,690 & 5,315 & 5,315 & 5,315 \\
\hline Capital spending & 20,665 & 18,111 & 22,083 & 22,083 & 23,337 & 27,948 & 27,948 & 27,948 \\
\hline Net lending & 1,102 & 228 & 743 & 634 & 1,981 & 1,785 & 1,785 & 1,785 \\
\hline Unallocated spending & 692 & 0 & 0 & 178 & 3,540 & 136 & 136 & 136 \\
\hline Overall cash balance (without measures) & $-15,205$ & $-10,030$ & $-16,108$ & $-12,104$ & $-16,662$ & $-17,485$ & $-23,343$ & $-14,112$ \\
\hline Measures (to be identified) & 0 & 0 & 0 & 0 & 0 & 0 & 6,785 & 0 \\
\hline Overall balance (cash basis) & $-15,205$ & $-10,030$ & $-16,108$ & $-12,104$ & $-16,662$ & $-17,485$ & $-16,559$ & $-14,112$ \\
\hline Net change in VAT refund arrears & 0 & 642 & 0 & 0 & 0 & 0 & 0 & 0 \\
\hline Net change in energy and utility arrears & -174 & 0 & 0 & 0 & 0 & 0 & 0 & 0 \\
\hline Net change in social arrears $5 /$ & -325 & $-2,255$ & 0 & 2,261 & 0 & 0 & 0 & 0 \\
\hline Noncash property income $7 /$ & 518 & 518 & 494 & 494 & 503 & 503 & 494 & 503 \\
\hline Overall balance (commitment basis) & $-14,188$ & $-7,899$ & $-15,615$ & $-13,872$ & $-16,159$ & $-16,982$ & $-16,065$ & $-13,609$ \\
\hline Financing & 14,980 & 10,052 & 16,108 & 12,104 & 16,662 & 17,485 & 16,559 & 14,112 \\
\hline External & 4,738 & 2,729 & 3,065 & 3,064 & 5,811 & 5,811 & 5,325 & 707 \\
\hline Domestic & -327 & $-14,546$ & 8,428 & 8,566 & 264 & 520 & 79 & 2,251 \\
\hline Privatization & 10,569 & 21,869 & 4,615 & 474 & 10,587 & 11,154 & 11,154 & 11,154 \\
\hline Statistical discrepancy & 225 & -22 & 0 & $\mathbf{0}$ & 0 & 0 & 0 & 0 \\
\hline
\end{tabular}


Table 5 (continued). Ukraine: General Government Finances, 2004-07 1/

\begin{tabular}{|c|c|c|c|c|c|c|c|c|}
\hline & \multirow[t]{2}{*}{2004} & \multirow[t]{2}{*}{2005} & \multicolumn{2}{|c|}{2006} & \multicolumn{4}{|c|}{2007} \\
\hline & & & Budget 2/ & Proj. & $\begin{array}{c}\text { Budget 2/ } \\
\text { First Reading } \\
\end{array}$ & $\begin{array}{c}\text { Budget } 2 / \\
\text { Second Reading } \\
\end{array}$ & $\begin{array}{l}\text { Authorities' } \\
\text { Policies 3/ } \\
\end{array}$ & $\begin{array}{c}\text { Recommended } \\
\text { Policies } 4 / \\
\end{array}$ \\
\hline & \multicolumn{8}{|c|}{ (In percent of GDP) } \\
\hline Revenue & 35.0 & 41.3 & 41.6 & 43.0 & 40.7 & 42.1 & 43.2 & 42.9 \\
\hline Tax revenue & 29.2 & 35.4 & 35.5 & 37.6 & 36.6 & 37.6 & 38.4 & 38.2 \\
\hline Personal income tax & 3.8 & 4.1 & 4.1 & 4.6 & 4.8 & 4.8 & 5.4 & 5.3 \\
\hline Enterprise profit tax & 4.7 & 5.5 & 5.1 & 5.0 & 4.2 & 4.6 & 4.6 & 4.6 \\
\hline Payroll tax & 8.4 & 9.4 & 9.1 & 9.3 & 10.0 & 10.0 & 10.2 & 10.0 \\
\hline Property tax & 0.7 & 0.6 & 0.6 & 0.6 & 0.5 & 0.5 & 0.5 & 0.5 \\
\hline VAT & 4.3 & 8.0 & 8.9 & 9.9 & 9.3 & 9.7 & 9.4 & 9.8 \\
\hline Other taxes on goods and services & 4.3 & 4.4 & 4.7 & 4.4 & 4.0 & 4.2 & 4.3 & 3.9 \\
\hline Taxes on international trade & 1.5 & 1.6 & 1.5 & 1.4 & 1.4 & 1.4 & 1.5 & 1.5 \\
\hline Other taxes & 1.5 & 1.8 & 1.6 & 2.4 & 2.2 & 2.2 & 2.5 & 2.6 \\
\hline Nontax, capital revenue, and grants & 5.8 & 5.9 & 6.1 & 5.4 & 4.1 & 4.5 & 4.8 & 4.7 \\
\hline Expenditure & 39.5 & 43.6 & 44.7 & 45.4 & 43.5 & 45.0 & 47.3 & 45.3 \\
\hline Current expenditures & 32.9 & 39.3 & 40.3 & 40.9 & 38.7 & 40.0 & 42.0 & 40.1 \\
\hline Wages & 7.4 & 7.8 & 8.6 & 8.7 & 7.9 & 7.9 & 8.3 & 8.2 \\
\hline Goods and services & 5.7 & 6.7 & 7.1 & 8.0 & 6.9 & 7.4 & 7.8 & 7.7 \\
\hline Subsidies & 2.2 & 2.3 & 2.8 & 2.9 & 3.0 & 3.7 & 3.9 & 3.0 \\
\hline Transfers & 16.7 & 21.7 & 20.9 & 20.7 & 20.1 & 20.1 & 21.1 & 20.4 \\
\hline Pensions 5/6/ & 12.1 & 17.1 & 15.5 & 15.4 & 15.2 & 15.2 & 16.0 & 15.3 \\
\hline Other & 4.6 & 4.6 & 5.4 & 5.3 & 4.9 & 4.9 & 5.1 & 5.1 \\
\hline Interest & 0.9 & 0.8 & 0.9 & 0.7 & 0.8 & 0.9 & 0.9 & 0.9 \\
\hline Capital spending & 6.0 & 4.3 & 4.3 & 4.4 & 3.9 & 4.7 & 4.9 & 4.9 \\
\hline Net lending & 0.3 & 0.1 & 0.1 & 0.1 & 0.3 & 0.3 & 0.3 & 0.3 \\
\hline Unallocated spending & 0.2 & 0.0 & 0.0 & 0.0 & 0.6 & 0.0 & 0.0 & 0.0 \\
\hline Overall cash balance (without measures) & -4.4 & -2.4 & -3.1 & -2.4 & -2.8 & -2.9 & -4.1 & -2.5 \\
\hline Measures (to be identified) & 0.0 & 0.0 & 0.0 & 0.0 & 0.0 & 0.0 & 1.2 & 0.0 \\
\hline Overall balance (cash basis) & -4.4 & -2.4 & -3.1 & -2.4 & -2.8 & -2.9 & -2.9 & -2.5 \\
\hline Net change in VAT refund arrears & 0.0 & 0.2 & 0.0 & 0.1 & 0.0 & 0.0 & 0.0 & -0.1 \\
\hline Net change in energy and utility arrears & -0.1 & 0.0 & 0.0 & 0.0 & 0.0 & 0.0 & 0.0 & 0.0 \\
\hline Net change in social arrears $5 /$ & -0.1 & -0.5 & 0.0 & 0.4 & 0.0 & 0.0 & 0.0 & 0.0 \\
\hline Noncash property income $7 /$ & 0.2 & 0.1 & 0.1 & 0.1 & 0.1 & 0.1 & 0.1 & 0.1 \\
\hline Overall balance (commitment basis) & -4.1 & -1.9 & -3.0 & -2.7 & -2.7 & -2.9 & -2.8 & -2.4 \\
\hline Financing & 4.3 & 2.4 & 3.1 & 2.4 & 2.8 & 2.9 & 2.9 & 2.5 \\
\hline External & 1.4 & 0.6 & 0.6 & 0.6 & 1.0 & 1.0 & 0.9 & 0.1 \\
\hline Domestic & -0.1 & -3.4 & 1.6 & 1.7 & 0.0 & 0.1 & 0.0 & 0.4 \\
\hline Privatization & 3.1 & 5.1 & 0.9 & 0.1 & 1.8 & 1.9 & 2.0 & 1.9 \\
\hline Statistical discrepancy & 0.1 & 0.0 & 0.0 & 0.0 & 0.0 & 0.0 & 0.0 & 0.0 \\
\hline \multicolumn{9}{|l|}{ Memorandum items: } \\
\hline Nominal GDP (Hrv millions) & 345,113 & 424,741 & 512,300 & 505,409 & 594,100 & 594,100 & 565,387 & 573,708 \\
\hline
\end{tabular}

Sources: Ministry of Finance; National Bank of Ukraine; and staff estimates and projections.

1/ Based on state budget expenditure appropriations, IMF staff macroeconomic and revenue estimates.

2/ Staff's estimate of the general government budget based on state budget, social funds, and partial local government budget data.

3/ Authorities' policies (see Table 2, footnote 1) under the baseline external outlook and macroeconomic framework.

4/ Staff recommended policies (see Table 2, footnote 2) under the baseline external outlook and macroeconomic framework.

$5 /$ In 2005, includes Hrv 2.3 billion in advanced pension payments paid in December, due in January 2006.

6/ In 2004-06, includes pensions on army, interior, emergency services, penitentiary, tax police and security paid directly by the State budget. Administration of

these payments was transferred to the Pension Fund from 2007 onwards.

7/ Excludes US\$ 98 million of non-cash property income paid annually by Russia in exchange for amortization of Ukraine's debt to Russia. 
Table 6. Ukraine: Monetary Accounts, 2003-07

\begin{tabular}{|c|c|c|c|c|c|c|c|c|c|}
\hline & \multirow{2}{*}{$\frac{2003}{\text { Dec. }}$} & \multirow{2}{*}{$\frac{2004}{\text { Dec. }}$} & \multirow{2}{*}{$\begin{array}{l}2005 \\
\text { Dec. }\end{array}$} & \multicolumn{4}{|c|}{2006} & \multicolumn{2}{|c|}{2007} \\
\hline & & & & Mar. & Jun. & Sep. & Dec. & $\begin{array}{c}\text { Dec. } \\
\text { Authori- } \\
\text { ties' } \\
\text { Policies 1/ } \\
\end{array}$ & $\begin{array}{c}\text { Dec. } \\
\text { Recom- } \\
\text { mended } \\
\text { Policies }\end{array}$ \\
\hline \multicolumn{10}{|l|}{ Monetary Survey } \\
\hline Net foreign assets & 25,538 & 42,289 & 79,312 & 68,451 & 67,154 & 68,077 & 61,914 & 65,806 & 71,210 \\
\hline (In millions of US dollars) & 4,785 & 7,966 & 15,700 & 13,550 & 13,292 & 13,481 & 12,260 & 13,031 & 13,580 \\
\hline Net domestic assets & 69,505 & 83,512 & 114,759 & 126,853 & 146,983 & 166,693 & 197,557 & 272,803 & 245,553 \\
\hline Domestic credit & 86,505 & 106,266 & 144,210 & 160,634 & 185,552 & 212,498 & 249,537 & 337,033 & 312,087 \\
\hline Net credit to government & 15,080 & 12,583 & $-7,078$ & $-5,223$ & $-2,156$ & $-5,562$ & 1,487 & 1,488 & 3,641 \\
\hline Credit to the economy & 71,425 & 93,683 & 151,288 & 165,857 & 187,707 & 218,061 & 248,050 & 335,545 & 308,447 \\
\hline Other items, net & $-17,000$ & $-22,754$ & $-29,451$ & $-33,781$ & $-38,569$ & $-45,806$ & $-51,980$ & $-64,230$ & $-66,534$ \\
\hline Broad money & 95,043 & 125,801 & 194,071 & 195,304 & 214,136 & 234,770 & 259,471 & 338,609 & 316,763 \\
\hline Currency in circulation & 33,119 & 42,345 & 60,231 & 58,640 & 64,298 & 68,611 & 76,881 & 98,942 & 92,558 \\
\hline Total deposits & 61,924 & 83,456 & 133,839 & 136,664 & 149,838 & 166,159 & 182,590 & 239,668 & 224,205 \\
\hline Domestic currency deposits & 42,138 & 53,060 & 88,062 & 85,268 & 91,111 & 100,444 & 110,693 & 143,028 & 131,350 \\
\hline Foreign currency deposits & 19,786 & 30,396 & 45,777 & 51,396 & 58,727 & 65,715 & 71,896 & 96,639 & 92,855 \\
\hline \multicolumn{10}{|l|}{ Accounts of the National Bank of Ukraine } \\
\hline Net international reserves $2 /$ & 27,199 & 42,015 & 91,925 & 81,785 & 83,669 & 92,201 & 102,072 & 116,065 & 123,475 \\
\hline (In millions of U.S. dollars) & 5,101 & 7,919 & 18,203 & 16,195 & 16,568 & 18,258 & 20,212 & 22,983 & 23,548 \\
\hline Net domestic assets $3 /$ & 12,891 & 11,748 & $-9,166$ & $-6,290$ & $-3,481$ & $-7,423$ & $-3,723$ & -759 & $-13,366$ \\
\hline Net domestic credit & 16,262 & 15,844 & $-7,647$ & $-5,534$ & $-2,615$ & $-5,932$ & $-2,252$ & 2,961 & $-5,335$ \\
\hline Net credit to government & 13,575 & 11,458 & $-8,729$ & $-6,714$ & $-4,105$ & $-7,437$ & $-3,248$ & $-3,248$ & $-1,095$ \\
\hline Credit to government & 18,548 & 16,720 & 9,733 & 9,719 & 9,720 & 9,705 & 9,733 & 9,733 & 9,733 \\
\hline Deposits of government & 4,973 & 5,263 & 18,462 & 16,433 & 13,825 & 17,142 & 12,981 & 12,981 & 10,828 \\
\hline Credit to the economy & 190 & 201 & 210 & 214 & 224 & 229 & 139 & 139 & 139 \\
\hline Net claims on banks & 2,497 & 4,186 & 872 & 966 & 1,266 & 1,276 & 857 & 6,070 & $-4,379$ \\
\hline Other items, net & $-3,372$ & $-4,096$ & $-1,519$ & -756 & -866 & $-1,492$ & $-1,471$ & $-3,720$ & $-8,031$ \\
\hline Base money & 40,089 & 53,763 & 82,760 & 75,495 & 80,188 & 84,777 & 98,350 & 115,306 & 110,110 \\
\hline Currency in circulation & 33,119 & 42,345 & 60,231 & 58,640 & 64,298 & 68,611 & 76,881 & 98,942 & 92,558 \\
\hline Banks' reserves & 6,970 & 11,418 & 22,528 & 16,855 & 15,890 & 16,166 & 21,468 & 16,364 & 17,551 \\
\hline \multicolumn{10}{|l|}{ Deposit Money Banks } \\
\hline Net foreign assets & $-1,924$ & $-1,526$ & $-14,713$ & $-14,458$ & $-18,063$ & $-25,575$ & $-42,233$ & $-52,333$ & $-54,339$ \\
\hline Net domestic assets & 66,039 & 88,671 & 148,329 & 151,043 & 167,940 & 191,465 & 225,679 & 298,070 & 274,165 \\
\hline Domestic credit & 72,740 & 94,608 & 152,728 & 167,134 & 189,433 & 219,706 & 252,575 & 340,070 & 312,972 \\
\hline Net credit to government & 1,505 & 1,125 & 1,651 & 1,491 & 1,949 & 1,875 & 4,736 & 4,736 & 4,736 \\
\hline Credit to the economy & 71,235 & 93,483 & 151,078 & 165,643 & 187,484 & 217,832 & 247,840 & 335,335 & 308,236 \\
\hline Banks' reserves & 6,970 & 11,418 & 22,528 & 16,855 & 15,890 & 16,166 & 21,468 & 16,364 & 17,551 \\
\hline Other items, net & $-13,672$ & $-17,355$ & $-26,927$ & $-32,946$ & $-37,382$ & $-44,407$ & $-48,364$ & $-58,364$ & $-56,358$ \\
\hline Banks' Liabilities & 64,114 & 87,145 & 133,616 & 136,585 & 149,878 & 165,890 & 183,446 & 245,738 & 219,826 \\
\hline Net credit to banks from NBU & 2,497 & 4,186 & 872 & 966 & 1,266 & 1,276 & 857 & 6,070 & $-4,379$ \\
\hline Deposits & 61,617 & 82,959 & 132,745 & 135,618 & 148,612 & 164,615 & 182,590 & 239,668 & 224,205 \\
\hline Memorandum items: & \multicolumn{9}{|c|}{ (Percent change year-over-year) } \\
\hline Base money & 30.1 & 34.1 & 53.9 & 25.2 & 22.4 & 20.3 & 18.8 & 17.2 & 12.0 \\
\hline Broad money & 46.5 & 32.4 & 54.3 & 39.4 & 37.0 & 37.3 & 33.7 & 30.5 & 22.1 \\
\hline \multirow[t]{2}{*}{ Credit to the economy } & 63.4 & 31.2 & 61.5 & 62.8 & 62.9 & 63.5 & 64.0 & 35.3 & 24.3 \\
\hline & \multicolumn{9}{|c|}{ (Ratio) } \\
\hline Velocity of broad money 4 / & 2.81 & 2.75 & 2.19 & 2.27 & 2.20 & 2.07 & 1.95 & 1.67 & 1.81 \\
\hline \multirow[t]{2}{*}{ Money multiplier } & 2.37 & 2.34 & 2.34 & 2.59 & 2.67 & 2.77 & 2.64 & 2.94 & 2.88 \\
\hline & \multicolumn{9}{|c|}{ (Percent) } \\
\hline Foreign currency to total loans & 38.4 & 39.0 & 40.5 & 41.5 & 43.2 & 45.0 & $\ldots$ & $\ldots$ & ... \\
\hline Foreign currency deposits to total deposits & 32.0 & 36.4 & 34.3 & 37.7 & 39.3 & 39.7 & $\ldots$ & $\ldots$ & $\ldots$ \\
\hline
\end{tabular}

Sources: National Bank of Ukraine; and staff estimates and projections.

1/ Authorities' policies (see Table 2, footnote 1) under the baseline external outlook and macroeconomic framework.

2/ Projected NIR are at projected exchange rates.

3/ NDA are calculated as the difference between base money and NIR.

4/ Based on nominal GDP over the last four quarters. 
Table 7. Ukraine: Financial Soundness Indicators for the Banking Sector, 2002-06

\begin{tabular}{|c|c|c|c|c|c|c|c|}
\hline & Dec-02 & Dec-03 & Dec-04 & Dec-05 & Mar-06 & Jun-06 & Sep-06 \\
\hline & \multicolumn{7}{|c|}{ (In percent, unless otherwise indicated) } \\
\hline \multicolumn{8}{|l|}{ Ownership } \\
\hline Number of banks & 157 & 158 & 160 & 165 & 165 & 165 & 166 \\
\hline Private & 155 & 156 & 158 & 163 & 163 & 163 & 164 \\
\hline Domestic & 135 & 137 & 139 & 140 & 136 & 133 & 132 \\
\hline Foreign & 20 & 19 & 19 & 23 & 27 & 30 & 32 \\
\hline$o / w: 100 \%$ foreign-owned & 7 & 7 & 7 & 9 & 11 & 11 & 11 \\
\hline State-owned & 2 & 2 & 2 & 2 & 2 & 2 & 2 \\
\hline \multicolumn{8}{|l|}{ Concentration } \\
\hline Share of assets of largest 10 banks & 54.1 & 53.7 & 53.1 & 53.8 & 53.2 & 53.0 & 53.4 \\
\hline Share of assets of largest 25 banks & 71.0 & 71.7 & 72.0 & 73.5 & 73.5 & 73.9 & 74.0 \\
\hline Number of bank with assets less than $\$ 150$ million & 140 & 132 & 124 & 121 & 118 & 117 & 111 \\
\hline \multicolumn{8}{|l|}{ Capital Adequacy } \\
\hline Capital to total assets & 14.7 & 12.3 & 13.1 & 11.5 & 11.5 & 11.2 & 11.2 \\
\hline \multicolumn{8}{|l|}{ Asset Quality } \\
\hline Credit growth (year-over-year) & 47.3 & 60.8 & 31.2 & 61.5 & 62.8 & 62.9 & 63.5 \\
\hline Credit-to-GDP ratio & 19.4 & 26.6 & 27.1 & 35.6 & 37.3 & 39.8 & 44.8 \\
\hline Change of credit-to-GDP ratio (percentage points) & 4.8 & 7.3 & -2.4 & 8.5 & 9.3 & 9.4 & 11.4 \\
\hline NPLs to total loans $1 / 2 /$ & 21.9 & 28.3 & 30.0 & 19.6 & 18.3 & 19.1 & 17.9 \\
\hline NPLs (excl. part of timely serviced substandard loans) $1 / 3$ / & $\ldots$ & 8.5 & 8.9 & 5.5 & 5.1 & 5.1 & 4.7 \\
\hline NPLs net of provisions to capital & 66.6 & 144.6 & 147.2 & 110.2 & 105.4 & 120.2 & 112.8 \\
\hline Specific provisions to NPLs $4 /$ & 37.0 & 22.3 & 21.1 & 25.0 & 25.9 & 23.7 & 24.6 \\
\hline Specific provisions to total loans & 8.1 & 6.3 & 6.3 & 6.0 & 5.8 & 5.5 & 5.4 \\
\hline \multicolumn{8}{|l|}{ Foreign Exchange-Rate Risk } \\
\hline Loans in foreign currency to total loans & 39.5 & 39.3 & 39.2 & 40.5 & 41.5 & 43.2 & 45.0 \\
\hline Deposits in foreign currency to total deposits & 32.2 & 33.5 & 36.5 & 34.2 & 37.6 & 39.2 & 39.5 \\
\hline Foreign currency loans to foreign currency deposits & 139.8 & 134.7 & 120.5 & 133.8 & 134.0 & 138.1 & 149.3 \\
\hline Total net open positions in foreign currency to regulatory capital & 21.5 & 17.7 & 14.7 & 8.6 & 8.1 & 10.0 & 8.8 \\
\hline $\begin{array}{l}\text { Total short-term foreign currency assets (incl. loans) to total short- } \\
\text { term foreign currency liabilities (incl. deposits) }\end{array}$ & 132.0 & 100.0 & 101.8 & 69.5 & 73.6 & 68.6 & 71.4 \\
\hline \multicolumn{8}{|l|}{ Liquidity Risk } \\
\hline Liquid assets to total assets & 13.5 & 15.3 & 16.7 & 16.4 & 13.9 & 13.1 & 12.6 \\
\hline Customer deposits to total loans to the economy & 87.6 & 87.1 & 89.2 & 88.5 & 82.4 & 79.8 & 76.2 \\
\hline Long-term assets to long-term liabilities & 94.8 & 108.9 & 113.1 & 116.3 & 123.2 & 129.5 & 129.6 \\
\hline Short-term assets to short-term liabilities & 129.7 & 118.3 & 117.9 & 111.5 & 106.9 & 102.0 & 101.2 \\
\hline \multicolumn{8}{|l|}{ Earnings and Profitability } \\
\hline Return on assets (after tax; end-of-period) & 1.2 & 1.0 & 1.1 & 1.3 & 1.4 & 1.6 & 1.7 \\
\hline Return on equity (after tax; end-of-period) & 8.0 & 7.6 & 8.4 & 10.4 & 11.8 & 13.6 & 14.0 \\
\hline Net interest margin to total assets & 6.0 & 5.8 & 4.9 & 4.9 & 4.8 & 5.0 & 5.2 \\
\hline \multicolumn{8}{|l|}{ Interest rate spreads (percentage points; end-of-period) } \\
\hline Between loans and deposits in domestic currency & 14.9 & 9.9 & 9.6 & 8.3 & 8.5 & 8.3 & 7.2 \\
\hline Between loans and deposits in foreign currency & 5.3 & 4.0 & 4.2 & 4.8 & 5.3 & 5.9 & 6.0 \\
\hline Between loans in domestic and foreign currency & 10.5 & 6.9 & 6.2 & 4.7 & 4.3 & 4.3 & 3.3 \\
\hline Between deposits in domestic and foreign currency & 0.9 & 1.1 & 0.8 & 1.2 & 1.0 & 1.9 & 2.1 \\
\hline \multicolumn{8}{|l|}{ Number of banks not complying with banking regulations } \\
\hline Not meeting capital adequacy requirements for Tier I capital & 1 & 1 & 2 & 1 & 2 & 1 & 0 \\
\hline Not meeting prudential regulations & 16 & 9 & 14 & 3 & 5 & 5 & 4 \\
\hline Not meeting reserve requirements & 2 & 0 & 11 & 3 & 3 & 1 & 1 \\
\hline
\end{tabular}

Sources: National Bank of Ukraine; and staff estimates.

1/ NPLs are those classified as substandard, doubtful, and loss.

2/ Increase in nonperforming loans (NPLs) in 2003 partly due to new classification rules.

3/ The NBU estimates that as of end-March 2004, 6.2 percent of loans classified as substandard were being timely serviced.

4/ About half of the drop in the provision to NPL ratio from end-2002 to end-2003 is due to new loan classification rules. 
Table 8. Ukraine: Medium-Term Macroeconomic Framework, Authorities' Policies 1/

\begin{tabular}{|c|c|c|c|c|c|c|c|c|c|}
\hline & \multirow[t]{2}{*}{2004} & \multirow[t]{2}{*}{2005} & \multirow[t]{2}{*}{2006} & 2007 & 2008 & 2009 & 2010 & 2011 & \multirow{2}{*}{$\begin{array}{c}\text { Cumulative } \\
\text { Change 2007-11 }\end{array}$} \\
\hline & & & & & \multicolumn{4}{|c|}{ Authorities' Policies } & \\
\hline \multicolumn{10}{|l|}{ Output and prices } \\
\hline Nominal GDP (billions of hryvnias) & 345.1 & 424.8 & 505.4 & 565.4 & 628.9 & 700.4 & 784.0 & 885.7 & \\
\hline Real GDP growth (percent change) & 12.1 & 2.6 & 6.0 & 4.3 & 4.8 & 4.7 & 5.0 & 5.3 & 26.5 \\
\hline Consumer prices (percent change; end of period) & 12.3 & 10.3 & 12.5 & 8.2 & 7.3 & 6.7 & 6.5 & 6.2 & 40.2 \\
\hline Consumer prices excl. energy (percent change; end of period) & 11.2 & 9.4 & 8.3 & 8.3 & 7.3 & 6.8 & 6.5 & 6.3 & 40.2 \\
\hline Consumer prices (percent change; average) & 9.0 & 13.5 & 9.1 & 12.9 & 7.7 & 7.0 & 6.6 & 6.4 & 47.5 \\
\hline \multicolumn{10}{|l|}{ Wages } \\
\hline Minimum wage (hryvnias per month; end of period) & 237.0 & 332.0 & 400.0 & 450.0 & 505.0 & 564.0 & 631.0 & 695.0 & \\
\hline Nominal monthly wages (average) & 27.7 & 36.5 & 23.3 & 14.8 & 12.1 & 11.5 & 11.4 & 11.2 & 77.8 \\
\hline Real monthly wages (average) & 17.1 & 20.3 & 13.0 & 1.7 & 4.0 & 4.2 & 4.5 & 4.6 & 20.5 \\
\hline \multicolumn{10}{|l|}{ Public finance (percent of GDP) } \\
\hline Cash balance & -4.4 & -2.4 & -2.4 & -2.9 & -2.5 & -2.5 & -2.5 & -2.5 & $\ldots$ \\
\hline Revenue and grants & 35.0 & 41.3 & 43.0 & 43.2 & 41.7 & 41.2 & 40.6 & 39.7 & $\ldots$ \\
\hline Expenditure and net lending (cash basis) & 39.5 & 43.6 & 45.4 & 46.1 & 44.2 & 43.7 & 43.1 & 42.2 & $\ldots$ \\
\hline Of which: currrent expenditure & 32.9 & 39.3 & 40.9 & 40.8 & 39.2 & 38.7 & 38.1 & 37.2 & \\
\hline Of which: interest payments & 0.9 & 0.8 & 0.7 & 0.9 & 0.7 & 0.6 & 0.6 & 0.6 & $\ldots$ \\
\hline Commitments balance & -4.1 & -1.9 & -2.7 & -2.8 & -2.4 & -2.5 & -2.5 & -2.4 & $\ldots$ \\
\hline Privatization receipts & 3.1 & 5.1 & 0.1 & 2.0 & 1.5 & 1.2 & 0.9 & 0.9 & $\ldots$ \\
\hline Net domestic financing & -0.1 & -3.4 & 1.7 & 0.0 & 0.4 & 0.7 & 0.8 & 0.7 & $\ldots$ \\
\hline Net external financing & 1.4 & 0.6 & 0.6 & 0.9 & 0.6 & 0.7 & 0.9 & 0.9 & $\ldots$ \\
\hline Public debt (end of period) 2/ & 25.5 & 19.4 & 16.8 & 15.5 & 14.5 & 14.0 & 14.2 & 14.3 & $\ldots$ \\
\hline Domestic & 6.3 & 4.7 & 4.6 & 4.1 & 4.1 & 4.4 & 4.7 & 4.9 & $\ldots$ \\
\hline External & 19.2 & 14.7 & 12.2 & 11.3 & 10.3 & 9.7 & 9.5 & 9.4 & $\ldots$ \\
\hline \multicolumn{10}{|l|}{ External sector } \\
\hline Current account balance (percent of GDP) & 10.5 & 3.1 & -1.0 & -3.9 & -6.6 & -8.4 & -9.0 & -8.5 & $\ldots$ \\
\hline Goods exports, value (percent change) & 40.8 & 4.8 & 12.9 & 6.0 & 4.8 & 6.3 & 6.5 & 7.8 & $\ldots$ \\
\hline Goods imports, value (percent change) & 23.7 & 21.8 & 21.3 & 14.3 & 12.8 & 10.9 & 8.5 & 6.4 & $\ldots$ \\
\hline Foreign direct investment (billions of U.S. dollars) & 2.7 & 9.0 & 3.8 & 4.9 & 4.5 & 4.4 & 4.3 & 4.3 & $\ldots$ \\
\hline \multicolumn{10}{|l|}{ Gross official reserves (end of period) } \\
\hline In billions of U.S. dollars & 9.5 & 19.4 & 21.1 & 23.5 & 22.9 & 20.3 & 17.0 & 14.3 & $\ldots$ \\
\hline In months of imports of goods and services & 2.7 & 4.6 & 4.2 & 4.2 & 3.7 & 3.1 & 2.4 & 1.9 & $\ldots$ \\
\hline External debt service (in percent of exports of goods and services) $2 /$ & 4.6 & 4.9 & 5.1 & 4.6 & 3.9 & 4.2 & 3.3 & 3.7 & \\
\hline Hryvnia per U.S. dollar (end of period) & 5.31 & 5.05 & 5.05 & & & & & $\ldots$ & $\ldots$ \\
\hline Goods terms of trade (percent change) & 9.6 & 6.1 & -3.5 & -8.8 & -5.9 & -3.6 & -2.6 & 0.2 & -19.1 \\
\hline Goods and services terms of trade (percent change) & 7.8 & 4.9 & -1.1 & -5.9 & -4.1 & -2.3 & -1.6 & 0.7 & -12.6 \\
\hline \multicolumn{10}{|l|}{ Savings-Investment Balance (percent of GDP) } \\
\hline Foreign savings & -10.5 & -3.1 & 1.0 & 3.9 & 6.6 & 8.4 & 9.0 & 8.5 & $\ldots$ \\
\hline Gross national savings & 29.7 & 25.2 & 21.3 & 18.5 & 16.6 & 14.9 & 14.4 & 15.0 & $\ldots$ \\
\hline Nongovernment & 27.9 & 23.3 & 19.3 & 16.5 & 14.4 & 12.7 & 12.3 & 12.8 & $\ldots$ \\
\hline Government & 1.8 & 1.9 & 2.0 & 2.0 & 2.1 & 2.1 & 2.1 & 2.2 & $\ldots$ \\
\hline Gross investment & 19.2 & 22.2 & 22.3 & 22.4 & 23.2 & 23.2 & 23.2 & 23.3 & $\ldots$ \\
\hline Nongovernment & 13.2 & 17.9 & 17.9 & 17.5 & 18.5 & 18.6 & 18.6 & 18.7 & $\ldots$ \\
\hline Government & 6.0 & 4.3 & 4.4 & 4.9 & 4.6 & 4.6 & 4.6 & 4.6 & $\ldots$ \\
\hline
\end{tabular}

Sources: Ukrainian authorities; and staff estimates and projections.

1/ Under baseline external outlook and authorities' policies. These are assumed to include: (i) a fixed exchange rate through 2009 , followed by a gradually widening exchange rate corridor; (ii) full pass-through of rising energy import prices to industry, but zero pass-through to consumers; (iii) a general government fiscal deficit of 2.9 percent of GDP in 2007 and 2.5 percent thereafter; and (iv) annual real wage growth of 5 percent.

2/ Government and government-guaranteed debt, and NBU debt. Excludes debts by state-owned enterprises. 

Table 9. Ukraine: Medium-Term Macroeconomic Framework,
Recommended Policies 1/

\begin{tabular}{|c|c|c|c|c|c|c|c|c|c|}
\hline & 2004 & 2005 & 2006 & 2007 & $\begin{array}{c}2008 \\
\text { Recomm }\end{array}$ & $\begin{array}{l}2009 \\
\text { ended } p\end{array}$ & $\begin{array}{l}2010 \\
\text { olicies }\end{array}$ & 2011 & $\begin{array}{c}\text { Cumulative } \\
\text { Change 2007-11 }\end{array}$ \\
\hline \multicolumn{10}{|l|}{ Output and prices } \\
\hline Nominal GDP (billions of hryvnias) & 345.1 & 424.8 & 505.4 & 573.7 & 646.1 & 725.0 & 808.6 & 906.6 & $\ldots$ \\
\hline Real GDP growth (percent change) & 12.1 & 2.6 & 6.0 & 4.5 & 5.3 & 5.7 & 5.6 & 5.4 & 29.6 \\
\hline Consumer prices (percent change; end of period) & 12.3 & 10.3 & 12.5 & 10.6 & 8.3 & 7.5 & 5.9 & 5.2 & 43.5 \\
\hline Consumer prices excl. energy (percent change; end of period) & 11.2 & 9.4 & 8.3 & 8.3 & 7.0 & 7.0 & 5.8 & 5.3 & 37.9 \\
\hline \multicolumn{10}{|l|}{ Wages } \\
\hline Minimum wage (hryvnias per month; end of period) & 237.0 & 332.0 & 400.0 & 433.0 & 463.3 & 495.7 & 537.4 & 579.7 & $\ldots$ \\
\hline Nominal monthly wages (average) & 27.7 & 36.5 & 23.3 & 14.3 & 11.0 & 10.1 & 9.6 & 9.5 & 67.6 \\
\hline Real monthly wages (average) & 17.1 & 20.3 & 13.0 & 0.6 & 1.4 & 2.0 & 2.7 & 3.7 & 10.9 \\
\hline \multicolumn{10}{|l|}{ Public finance (percent of GDP) } \\
\hline Cash balance & -4.4 & -2.4 & -2.4 & -2.5 & -2.5 & -2.5 & -2.5 & -2.5 & $\ldots$ \\
\hline Revenue and grants & 35.0 & 41.3 & 43.0 & 42.9 & 41.0 & 40.1 & 39.4 & 38.6 & $\ldots$ \\
\hline Of which: currrent expenditure & 32.9 & 39.3 & 40.9 & 40.1 & 38.3 & 37.1 & 36.2 & 34.9 & \\
\hline Of which: interest payments & 0.9 & 0.8 & 0.7 & 0.9 & 0.7 & 0.7 & 0.7 & 0.7 & $\ldots$ \\
\hline Commitments balance & -4.1 & -1.9 & -2.7 & -2.4 & -2.4 & -2.4 & -2.4 & -2.4 & $\ldots$ \\
\hline Privatization receipts & 3.1 & 5.1 & 0.1 & 1.9 & 1.6 & 1.3 & 1.0 & 0.9 & $\cdots$ \\
\hline Net domestic financing & -0.1 & -3.4 & 1.7 & 0.4 & 0.8 & 1.6 & 1.5 & 2.1 & $\ldots$ \\
\hline Net external financing & 1.4 & 0.6 & 0.6 & 0.1 & 0.0 & -0.5 & -0.1 & -0.5 & $\ldots$ \\
\hline Public debt (end of period) 2/ & 25.5 & 19.4 & 16.8 & 14.6 & 13.4 & 13.2 & 13.2 & 13.2 & $\cdots$ \\
\hline Domestic & 6.3 & 4.7 & 4.6 & 4.0 & 4.2 & 5.2 & 6.1 & 7.4 & $\ldots$ \\
\hline External & 19.2 & 14.7 & 12.2 & 10.6 & 9.2 & 8.0 & 7.1 & 5.7 & $\ldots$ \\
\hline \multicolumn{10}{|l|}{ External sector } \\
\hline Current account balance (percent of GDP) & 10.5 & 3.1 & -1.0 & -3.1 & -5.1 & -5.4 & -5.5 & -5.6 & $\ldots$ \\
\hline Goods exports, value (percent change) & 40.8 & 4.8 & 12.9 & 8.2 & 7.0 & 9.4 & 8.0 & 6.7 & $\ldots$ \\
\hline Goods imports, value (percent change) & 23.7 & 21.8 & 21.3 & 14.4 & 13.1 & 10.3 & 8.6 & 7.0 & $\ldots$ \\
\hline Foreign direct investment (billions of U.S. dollars) & 2.7 & 9.0 & 3.8 & 4.9 & 4.8 & 4.7 & 4.5 & 4.4 & $\ldots$ \\
\hline \multicolumn{10}{|l|}{ Gross official reserves (end of period) } \\
\hline In billions of U.S. dollars & 9.5 & 19.4 & 21.1 & 24.1 & 25.5 & 26.5 & 27.9 & 29.3 & $\ldots$ \\
\hline In months of imports of goods and services & 2.7 & 4.4 & 4.2 & 4.3 & 4.2 & 4.1 & 4.0 & 4.0 & $\ldots$ \\
\hline Goods terms of trade (percent change) & 9.6 & 6.1 & -3.5 & -8.8 & -6.3 & -3.9 & -3.3 & 0.2 & -20.4 \\
\hline Goods and services terms of trade (percent change) & 7.8 & 4.9 & -1.1 & -5.8 & -4.3 & -2.6 & -2.2 & 0.5 & -13.7 \\
\hline \multicolumn{10}{|l|}{ Savings-Investment Balance (percent of GDP) } \\
\hline Foreign savings & -10.5 & -3.1 & 1.0 & 3.1 & 5.1 & 5.4 & 5.5 & 5.6 & $\ldots$ \\
\hline Gross national savings & 29.7 & 25.2 & 21.3 & 19.6 & 18.4 & 18.8 & 19.2 & 20.0 & $\cdots$ \\
\hline Nongovernment & 27.9 & 23.3 & 19.3 & 17.2 & 16.1 & 16.2 & 16.4 & 16.7 & $\ldots$ \\
\hline Government & 1.8 & 1.9 & 2.0 & 2.4 & 2.4 & 2.6 & 2.9 & 3.3 & $\ldots$ \\
\hline Gross investment & 19.2 & 22.2 & 22.3 & 22.7 & 23.6 & 24.2 & 24.8 & 25.6 & $\ldots$ \\
\hline Nongovernment & 13.2 & 17.9 & 17.9 & 17.9 & 18.7 & 19.1 & 19.4 & 19.8 & $\ldots$ \\
\hline Government & 6.0 & 4.3 & 4.4 & 4.9 & 4.9 & 5.1 & 5.4 & 5.8 & $\ldots$ \\
\hline
\end{tabular}

Sources: Ukrainian authorities; and staff estimates and projections.

1/ Under baseline external outlook. This scenario assumes (i) full pass-through of energy import prices; (ii) a more flexible exchange rate; (iii) a general government deficit of 2.5 percent of GDP through the medium term; and (iv) minimum wage growth in line with the CPI excluding energy.

2/ Government and government-guaranteed debt, and NBU debt. Excludes debts by state-owned enterprises. 
Table 10. Ukraine: Moving to Inflation Targeting: Progress Report

\begin{tabular}{|c|c|c|}
\hline Preconditions & Key Achievements & Further Steps Needed 1/ \\
\hline $\begin{array}{l}\text { Mandate } \\
\text { to pursue } \\
\text { price } \\
\text { stability }\end{array}$ & $\begin{array}{l}\text { Drafted a Memorandum of Understanding (MoU) that sets out } \\
\text { the roles of the NBU and the government in inflation } \\
\text { targeting. } \\
\text { - Submitted draft amendments to the NBU Law that would } \\
\text { increase the independence of the NBU. }\end{array}$ & $\begin{array}{l}\text { - Agree with the government on the MoU. } \\
\text { - Adopt further amendments to the NBU Act that would provide } \\
\text { the NBU with a clear mandate to achieve price stability and } \\
\text { allow for greater NBU independence. }\end{array}$ \\
\hline $\begin{array}{l}\text { Exchange- } \\
\text { rate } \\
\text { flexibility }\end{array}$ & $\begin{array}{l}\text { - Allowed the hryvnia/U.S. dollar rate to fluctuate in a } 1 \text { percent } \\
\text { band. }\end{array}$ & $\begin{array}{l}\text { - Draw up concrete operational transition plan, including on the } \\
\text { changing role of the exchange rate. } \\
\text { - Gradually allow greater exchange-rate flexibility. }\end{array}$ \\
\hline $\begin{array}{l}\text { Monetary-policy } \\
\text { instruments }\end{array}$ & & $\begin{array}{l}\text { - Identify key policy rate; assess possibility to introduce an } \\
\text { interest rate corridor. } \\
\text { - Actively steer a short-term interest rate. } \\
\text { - Apply monetary instruments in a consistent, transparent, and } \\
\text { - } \text { market-orient manner. } \\
\text { Phase out the long-term refinancing facility. }\end{array}$ \\
\hline $\begin{array}{l}\text { Capacity to model and } \\
\text { forecast }\end{array}$ & $\begin{array}{l}\text { - Developed a small macroeconomic model. } \\
\text { - Compiled an inflation report, including inflation forecasts. } \\
\text { - Published a business survey, including on inflation } \\
\text { expectations. }\end{array}$ & $\begin{array}{l}\text { - Improve macroeconomic modeling. } \\
\text { - Develop core inflation indicators. }\end{array}$ \\
\hline $\begin{array}{l}\text { Communication of } \\
\text { monetary policies }\end{array}$ & $\begin{array}{l}\text { - Issued a brochure and an analytical paper on inflation } \\
\text { targeting and the transmission mechanism of monetary } \\
\text { policy. } \\
\text { - Issued a monetary-policy report. } \\
\text { - Held seminars on inflation targeting within the NBU and for } \\
\text { commercial banks. }\end{array}$ & $\begin{array}{l}\text { - } \text { Modernize the NBU website. } \\
\text { - Conduct press conferences and issue press releases on } \\
\text { inflation targeting. } \\
\text { - Issue an Inflation Report. }\end{array}$ \\
\hline $\begin{array}{l}\text { Financial market } \\
\text { development }\end{array}$ & - Liberalized the foreign-exchange market in August 2005. & $\begin{array}{l}\text { - Abolish the foreign-exchange turnover tax. } \\
\text { - Develop benchmark government securities. } \\
\text { - Simplify procedures for working in the foreign-exchange } \\
\text { market. }\end{array}$ \\
\hline Banking-sector stability & $\begin{array}{l}\text { Developed a strategy for the medium-term development of } \\
\text { the banking sector and supervision. }\end{array}$ & $\begin{array}{l}\text { - Gradually implement more risk-based supervision. } \\
\text { - Further tighten banking supervision, regulation, and } \\
\text { legislation. }\end{array}$ \\
\hline
\end{tabular}

1/ Most of the steps listed here are part of the NBU's Action Plan toward adopting inflation targeting, which was adopted by the NBU Board in January 2006. 
Table 11. Ukraine: Millennium Development Goals

\begin{tabular}{|c|c|c|c|c|c|c|}
\hline & 1990 & 1994 & 1997 & 2000 & 2003 & 2004 \\
\hline \multicolumn{7}{|l|}{ Goal 1. Eradicate extreme poverty and hunger } \\
\hline Population below minimum level of dietary energy consumption (in percent) & .. & .. & .. & .. & 3.0 & 3.0 \\
\hline Poverty headcount, national (percent of population) & .. & .. & .. & .. & 2.0 & 2.0 \\
\hline Prevalence of underweight in children (under five years of age) & .. & .. & .. & 3.0 & 1.0 & . \\
\hline \multicolumn{7}{|l|}{ Goal 2. Achieve universal primary education } \\
\hline Net primary enrollment ratio (percent of relevant age group) & .. & .. & .. & .. & 85.0 & 86.0 \\
\hline Primary completion rate, total (percent of relevant age group) & 100.6 & 93.5 & .. & 88.8 & .. & . \\
\hline Proportion of pupils starting grade 1 who reach grade 5 & .. & .. & .. & .. & .. & . \\
\hline Youth literacy rate (percent ages $15-24$ ) & 100 & .. & .. & .. & .. & 100 \\
\hline \multicolumn{7}{|l|}{ Goal 3: Promote gender equality and empower women } \\
\hline Proportion of seats held by women in national parliament (percent) & 10.8 & .. & 8.7 & 9.9 & 12.7 & .. \\
\hline Ratio of girls to boys in primary and secondary education (percent) & .. & .. & .. & 99.5 & 99.2 & 98.5 \\
\hline Ratio of young literate females to males (percent ages 15-24) & 100 & .. & .. & .. & .. & 100.1 \\
\hline Share of women employed in the nonagricultural sector (percent) & 50.0 & 51.0 & 52.0 & 53.0 & 54.0 & 54.0 \\
\hline \multicolumn{7}{|l|}{ Goal 4: Reduce child mortality } \\
\hline Immunization, measles (percent of children ages $12-23$ months) & .. & 96.0 & 97.0 & 99.0 & 99.0 & 99.0 \\
\hline Infant mortality rate (per 1,000 live births) & 19.0 & .. & .. & 18.0 & .. & 14.0 \\
\hline Under 5 mortality rate (per 1,000$)$ & 26.0 & .. & .. & 24.0 & .. & 18.0 \\
\hline \multicolumn{7}{|l|}{ Goal 5: Improve maternal health } \\
\hline Maternal mortality ratio (modeled estimate, per 100,000 live births) & .. & .. & .. & 35.0 & .. & . \\
\hline \multicolumn{7}{|l|}{ Goal 6: Combat HIVIAIDS, malaria, and other diseases } \\
\hline Incidence of tuberculosis (per 100,000 people) & 41.5 & .. & .. & .. & .. & 100.5 \\
\hline Prevalence of HIV, total (percent of population aged 15-49) & .. & .. & .. & .. & 1.0 & 1.0 \\
\hline \multicolumn{7}{|l|}{ Goal 7: Ensure environmental sustainability } \\
\hline Access to an improved water source (percent of population) & .. & .. & .. & .. & 98.0 & . \\
\hline Access to improved sanitation (percent of population) & 99.0 & .. & .. & .. & 99.0 & . \\
\hline CO2 emissions (metric tons per capita) & 0.8 & 0.8 & 0.8 & 0.8 & .. & . \\
\hline Forest area (percent of total land area) & 28.9 & .. & .. & 26.1 & .. & . \\
\hline GDP per unit of energy use (2000 PPP \$ per kg oil equivalent) & .. & 2.0 & 1.0 & 2.0 & 2.0 & 2.0 \\
\hline Nationally protected areas (percent of total land area) & .. & .. & .. & .. & 3.9 & 3.9 \\
\hline \multicolumn{7}{|l|}{ Goal 8: Develop a global partnership for development } \\
\hline Aid per capita (current US\$) & 5.6 & 5.6 & 5.3 & 11.0 & 6.8 & 7.6 \\
\hline Fixed line and mobile phone subscribers (per 1,000 people) & 135.4 & 155.4 & 187.1 & 228.5 & 368.3 & 545.3 \\
\hline Internet users (per 1,000 people) & 0.0 & 0.1 & 2.0 & 7.1 & 52.3 & 79.0 \\
\hline Personal computers (per 1,000 people) & 1.9 & 6.9 & 11.9 & 18.1 & 23.5 & 28.0 \\
\hline
\end{tabular}

Source: World Development Indicators database, September 2006. 
Ukraine: Public Sector Debt Sustainability Framework, 2001-2011 (In percent of GDP, unless otherwise indicated)

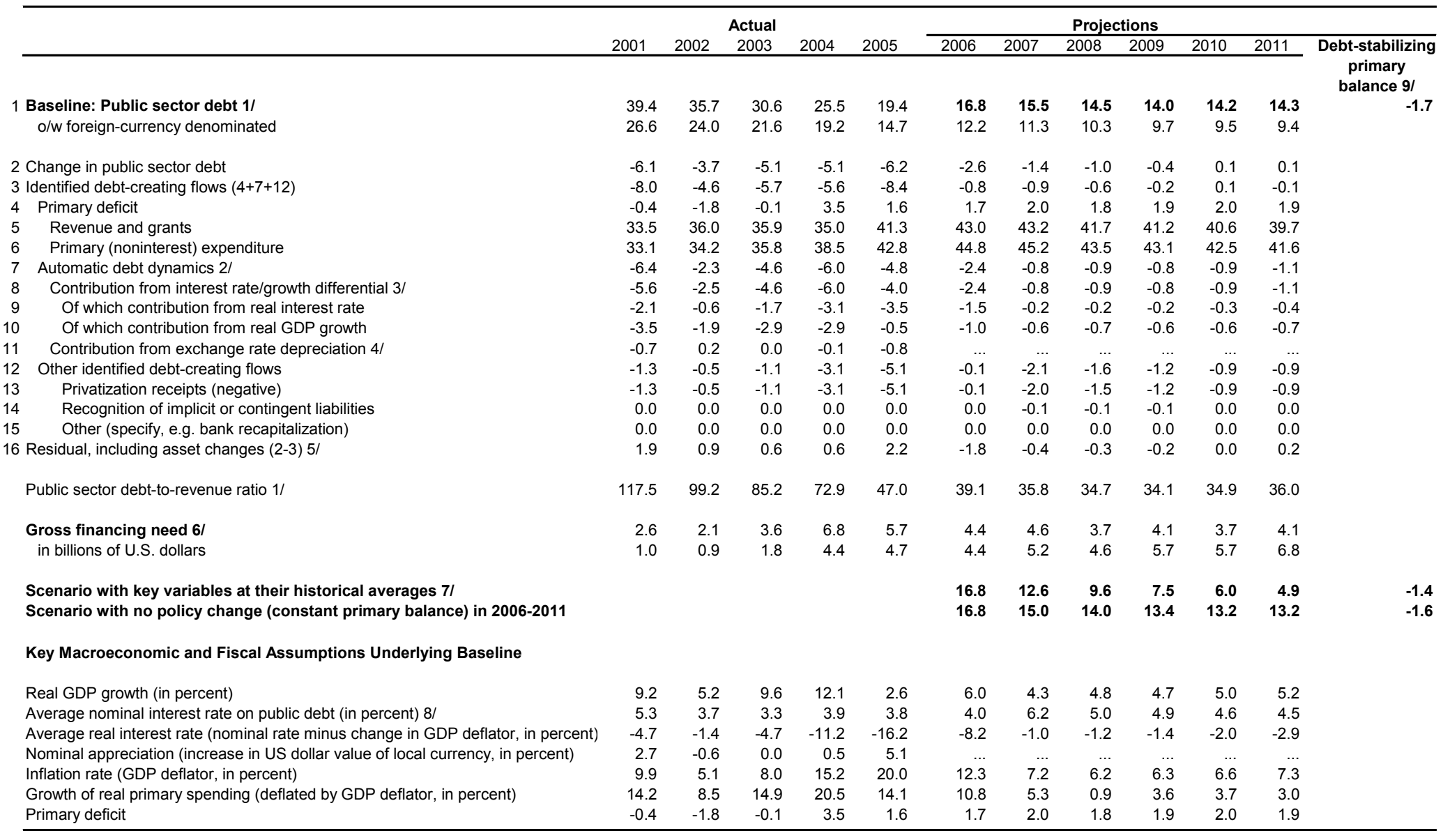

$1 /$ Gross debt measure for general government.

2/ Derived as $[(r-p(1+g)-g+a e(1+r)] /(1+g+p+g p))$ times previous period debt ratio, with $r=$ interest rate; $p=$ growth rate of GDP deflator; $g=$ real GDP growth rate; $a=$ share of foreign-currency denominated debt; and e = nominal exchange rate depreciation (measured by increase in local currency value of U.S. dollar).

$3 /$ The real interest rate contribution is derived from the denominator in footnote $2 /$ as $r-\pi(1+g)$ and the real growth contribution as $-g$.

$4 /$ The exchange rate contribution is derived from the numerator in footnote $2 /$ as ae(1+r).

$5 /$ For projections, this line includes exchange rate changes.

6/ Defined as public sector deficit, plus amortization of medium and long-term public sector debt, plus short-term debt at end of previous period.

7/ The key variables include real GDP growth; real interest rate; and primary balance in percent of GDP.

$8 /$ Derived as nominal interest expenditure divided by previous period debt stock.

9/ Assumes that key variables (real GDP growth, real interest rate, and other identified debt-creating flows) remain at the level of the last projection year. 
Ukraine: Public Debt Sustainability: Bound Tests 1/

(Public debt in percent of GDP)

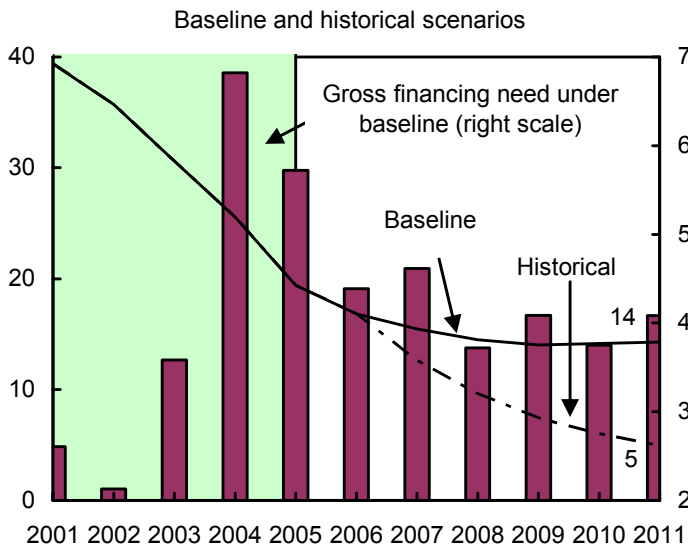

Growth shock (in percent per year)

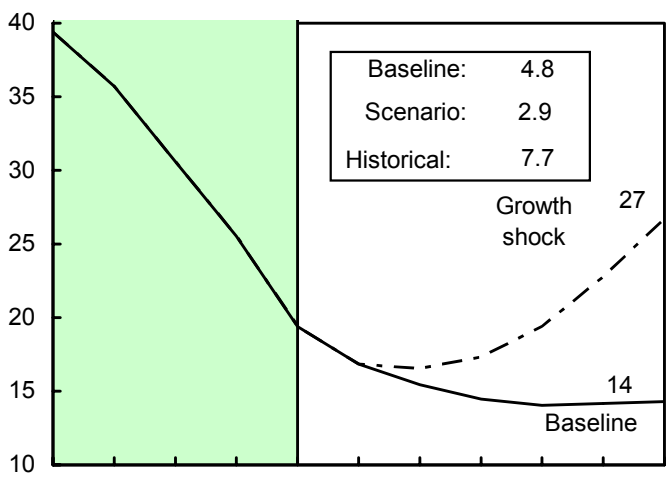

20012002200320042005200620072008200920102011

Combined shock $2 /$

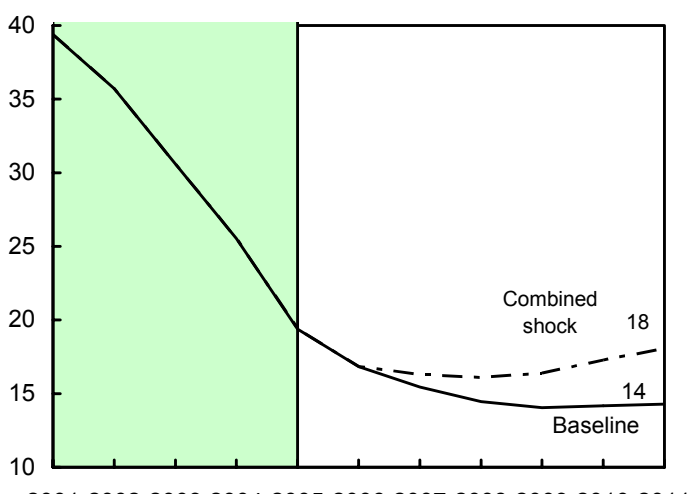

20012002200320042005200620072008200920102011

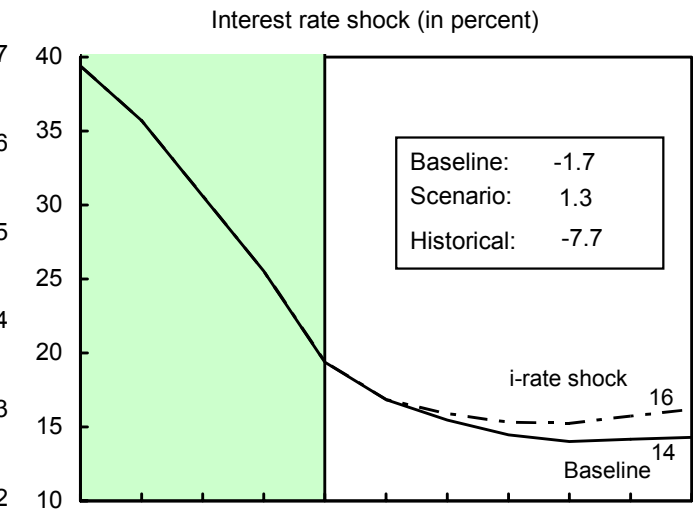

20012002200320042005200620072008200920102011

Primary balance shock (in percent of GDP) and no policy change scenario (constant primary balance)

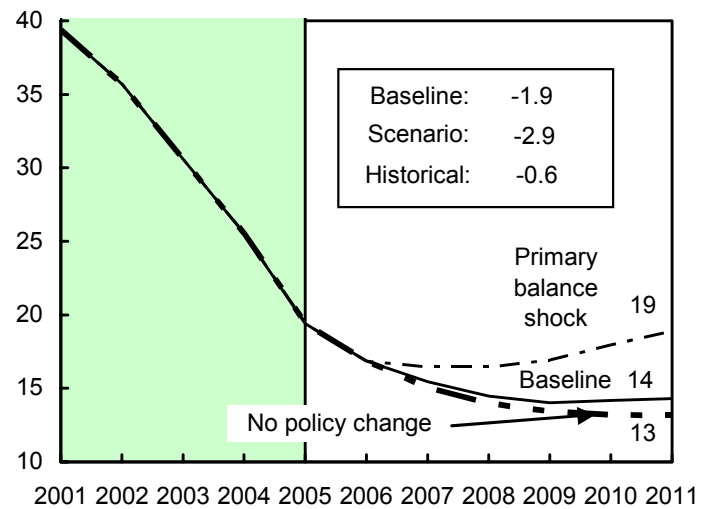

Real depreciation and contingent liabilities shocks 3/

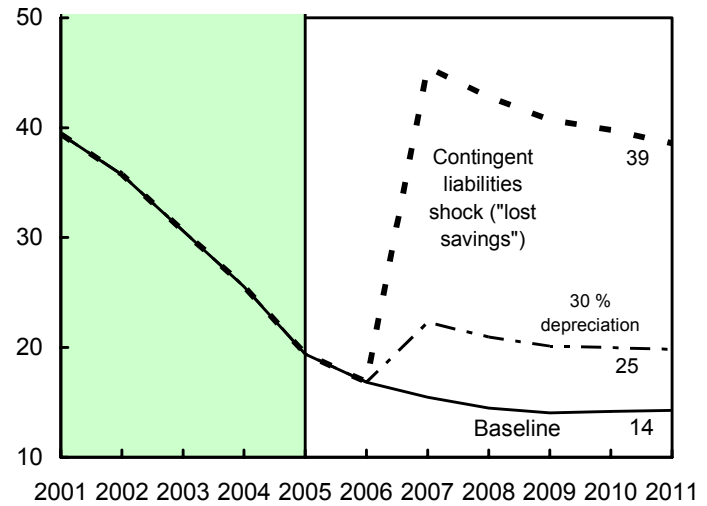

Sources: Ukrainian authorities; and staff estimates.

1/ Shaded areas represent actual data. Individual shocks are permanent one-half standard deviation shocks. Figures in the boxes represent average projections for the respective variables in the baseline and scenario being presented. Five-year historical average for the variable is also shown.

2/ Permanent $1 / 4$ standard deviation shocks applied to real interest rate, growth rate, and primary balance.

3 / One-time real depreciation of 30 percent and 30 percent of GDP shock to contingent liabilities associated with lost savings in USSR's Savings Bank occur in 2007, with real depreciation defined as nominal depreciation (measured by percentage fall in dollar value of local currency) minus domestic inflation (based on GDP deflator). 
Ukraine: External Debt Sustainability Framework, 2001-2011

(In percent of GDP, unless otherwise indicated)

\begin{tabular}{|c|c|c|c|c|c|c|c|c|c|c|c|c|c|}
\hline & & \multicolumn{5}{|c|}{ Actual } & \multicolumn{7}{|c|}{ Projections } \\
\hline & & 2001 & 2002 & 2003 & 2004 & 2005 & 2006 & 2007 & 2008 & 2009 & 2010 & 2011 & Debt-stabilizing \\
\hline \multirow{2}{*}{\multicolumn{2}{|c|}{1 Baseline: External debt }} & & & & & & & & & & & & it account \\
\hline & & 55.5 & 52.1 & 47.6 & 47.3 & 46.6 & 48.3 & 49.4 & 50.3 & 51.3 & 53.8 & 55.6 & -8.9 \\
\hline \multicolumn{2}{|r|}{2 Change in external debt } & -8.1 & -3.5 & -4.5 & -0.2 & -0.7 & 1.7 & 1.0 & 0.9 & 1.0 & 2.5 & 1.8 & \\
\hline \multicolumn{2}{|r|}{3 Identified external debt-creating flows $(4+8+9)$} & -14.7 & -10.8 & -14.9 & -27.3 & -25.7 & -6.7 & -5.7 & -3.0 & -1.4 & -1.0 & -1.7 & \\
\hline 4 & Current account deficit, excluding interest payments & -5.7 & -9.1 & -7.2 & -11.9 & -4.7 & -1.5 & 1.3 & 3.9 & 5.6 & 6.1 & 5.4 & \\
\hline 5 & Deficit in balance of goods and services & -1.6 & -4.4 & -2.6 & -7.7 & -0.8 & 2.6 & 5.3 & 7.8 & 9.3 & 9.7 & 8.8 & \\
\hline 6 & Exports & 55.5 & 55.1 & 57.8 & 63.6 & 53.5 & 50.8 & 48.6 & 46.2 & 44.1 & 43.6 & 43.1 & \\
\hline 7 & Imports & 53.9 & 50.7 & 55.2 & 56.0 & 52.7 & 53.4 & 53.9 & 54.0 & 53.4 & 53.3 & 51.9 & \\
\hline 8 & Net non-debt creating capital inflows (negative) & 0.3 & 2.4 & -1.0 & -5.8 & -12.4 & -5.4 & -7.7 & -7.4 & -7.6 & -7.6 & -7.6 & \\
\hline 9 & Automatic debt dynamics $1 /$ & -9.2 & -4.1 & -6.7 & -9.6 & -8.6 & 0.2 & 0.8 & 0.6 & 0.7 & 0.6 & 0.5 & \\
\hline 10 & Contribution from nominal interest rate & 2.0 & 1.6 & 1.4 & 1.3 & 1.7 & 2.5 & 2.7 & 2.7 & 2.8 & 3.0 & 3.1 & \\
\hline 11 & Contribution from real GDP growth & -4.8 & -2.6 & -4.2 & -4.4 & -1.0 & -2.3 & -1.9 & -2.1 & -2.1 & -2.4 & -2.6 & \\
\hline 12 & Contribution from price and exchange rate changes $2 /$ & -6.5 & -3.2 & -3.8 & -6.4 & -9.3 & $\ldots$ & $\ldots$ & $\ldots$ & $\ldots$ & $\ldots$ & $\ldots$ & \\
\hline \multicolumn{2}{|r|}{13 Residual, incl. change in gross foreign assets $(2-3) 3 /$} & 6.7 & 7.4 & 10.4 & 27.0 & 25.0 & 8.4 & 6.7 & 3.9 & 2.4 & 3.4 & 3.6 & \\
\hline \multicolumn{2}{|r|}{ External debt-to-exports ratio (in percent) } & 100.1 & 94.5 & 82.4 & 74.4 & 87.1 & 95.2 & 101.6 & 108.8 & 116.3 & 123.3 & 129.1 & \\
\hline \multirow{2}{*}{\multicolumn{2}{|c|}{$\begin{array}{l}\text { Gross external financing need (in billions of US dollars) } 4 \text { / } \\
\text { in percent of GDP }\end{array}$}} & 7.2 & 6.0 & 7.3 & 4.0 & 9.5 & 15.3 & 20.5 & 25.0 & 29.6 & 32.1 & 33.8 & \\
\hline & & 18.9 & 14.2 & 14.6 & 6.2 & 11.5 & 15.3 & 18.4 & 20.1 & 21.4 & 21.5 & 20.9 & \\
\hline \multicolumn{3}{|c|}{ Scenario with key variables at their historical averages $5 /$} & & & & & 48.3 & 39.2 & 28.0 & 16.9 & 6.5 & -2.3 & -3.0 \\
\hline \multicolumn{14}{|c|}{ Key Macroeconomic Assumptions Underlying Baseline } \\
\hline \multicolumn{2}{|r|}{ Real GDP growth (in percent) } & 9.2 & 5.2 & 9.6 & 12.1 & 2.6 & 6.0 & 4.3 & 4.8 & 4.8 & 5.0 & 5.3 & \\
\hline \multicolumn{2}{|r|}{ GDP deflator in US dollars (change in percent) } & 11.3 & 6.0 & 7.9 & 15.5 & 24.5 & 13.9 & 7.2 & 6.2 & 6.3 & 2.6 & 3.2 & \\
\hline \multicolumn{2}{|r|}{ Nominal external interest rate (in percent) } & 3.9 & 3.3 & 3.1 & 3.4 & 4.5 & 6.6 & 6.1 & 6.2 & 6.2 & 6.2 & 6.3 & \\
\hline \multicolumn{2}{|r|}{ Growth of exports (US dollar terms, in percent) } & 8.0 & 10.7 & 24.0 & 42.6 & 7.5 & 14.5 & 7.1 & 5.7 & 6.3 & 6.5 & 7.3 & \\
\hline \multicolumn{2}{|r|}{ Growth of imports (US dollar terms, in percent) } & 14.1 & 5.0 & 28.7 & 31.3 & 20.4 & 22.3 & 12.8 & 11.5 & 10.2 & 7.4 & 5.8 & \\
\hline \multirow{2}{*}{\multicolumn{2}{|c|}{ Current account balance, excluding interest payments }} & 5.7 & 9.1 & 7.2 & 11.9 & 4.7 & 1.5 & -1.3 & -3.9 & -5.6 & -6.1 & -5.4 & \\
\hline & & -0.3 & -2.4 & 1.0 & 5.8 & 12.4 & 5.4 & 7.7 & 7.4 & 7.6 & 7.6 & 7.6 & \\
\hline
\end{tabular}

1/ Derived as $[r-g-r(1+g)+$ ea $(1+r)](1+g+r+g r)$ times previous period debt stock, with $r=$ nominal effective interest rate on external debt; $r=$ change in domestic GDP deflator in US dollar terms, $g=$ real GDP growth rate, $\mathrm{e}=$ nominal appreciation (increase in dollar value of domestic currency), and $\mathrm{a}=$ share of domestic-currency denominated debt in total external debt.

$2 /$ The contribution from price and exchange rate changes is defined as $[-r(1+g)+e a(1+r)] /(1+g+r+g r)$ times previous period debt stock. $r$ increases with an appreciating domestic currency $(e>0)$ and rising inflation $($ based on GDP deflator) $3 /$ For projection, line includes the impact of price and exchange rate changes.

4/ Defined as current account deficit, plus amortization on medium- and long-term debt, plus short-term debt at end of previous period.

5/ The key variables include real GDP growth; nominal interest rate; dollar deflator growth; and both non-interest current account and non-debt inflows in percent of GDP.

6/ Long-run, constant balance that stabilizes the debt ratio assuming that key variables (real GDP growth, nominal interest rate, dollar deflator growth, and non-debt inflows in percent of GDP) remain at their levels

of the last projection year. 
Ukraine: External Debt Sustainability: Bound Tests 1/ (External debt in percent of GDP)
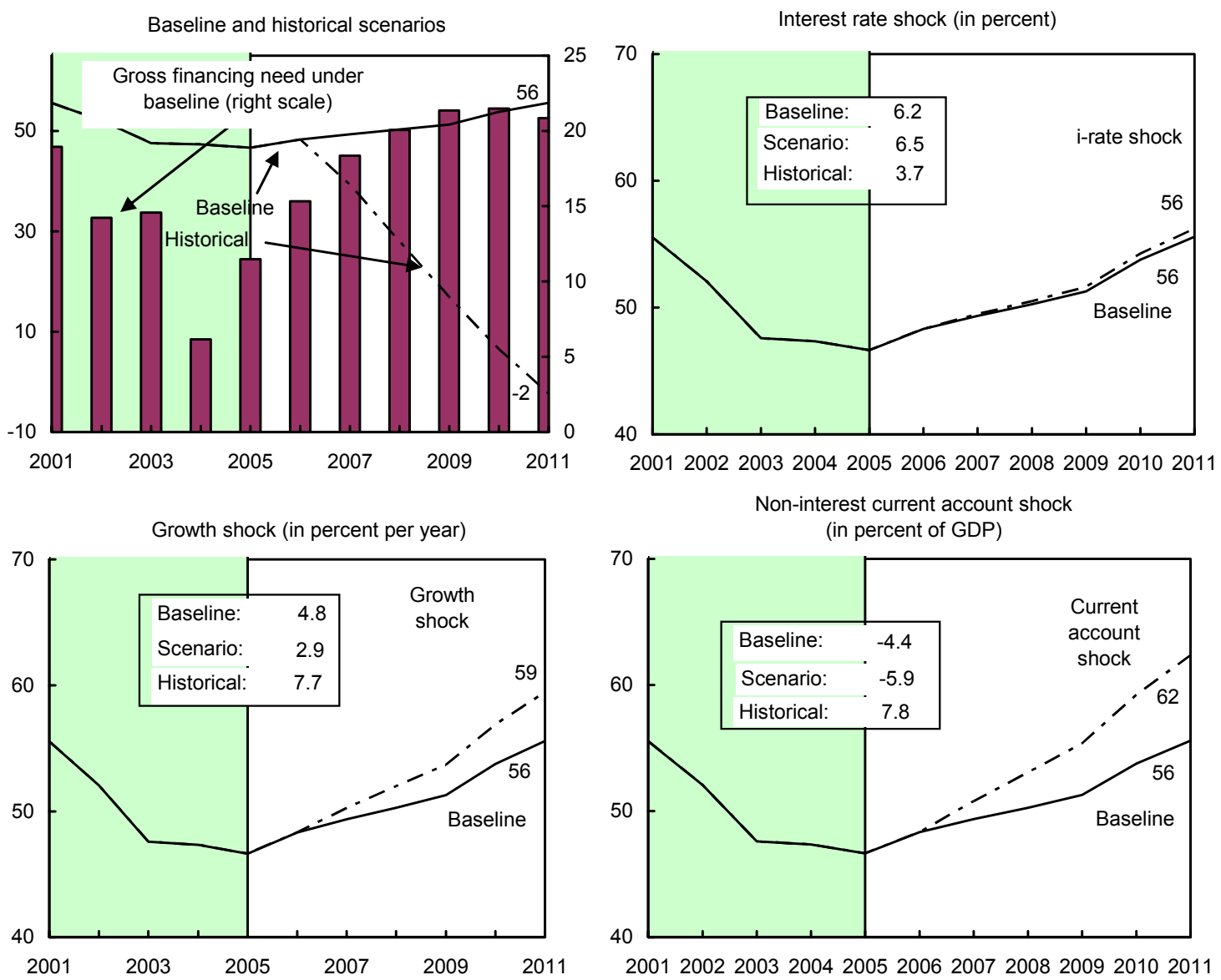

Combined shock 2/
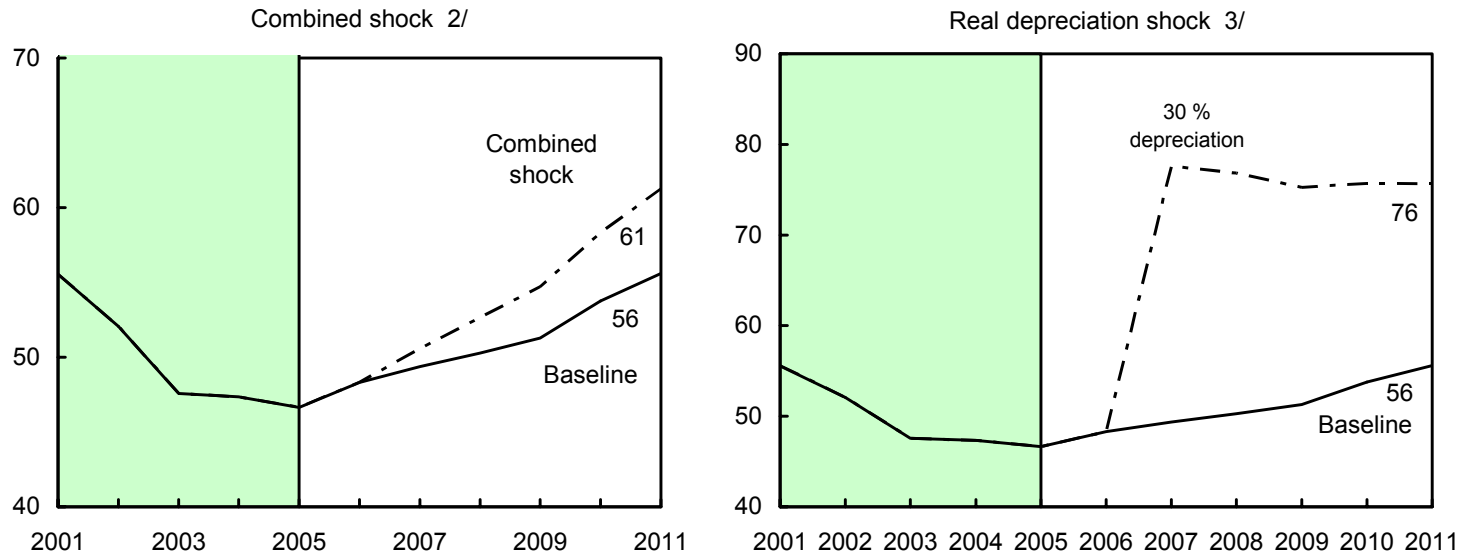

Sources: Ukranian authorities; and staff estimates.

$1 /$ Shaded areas represent actual data. Individual shocks are permanent one-half standard deviation shocks. Figures in the boxes represent average projections for the respective variables in the baseline and scenario being presented. Five-year historical average for the variable is also shown. 2/ Permanent 1/4 standard deviation shocks applied to real interest rate, growth rate, and current account balance.

3/ One-time real depreciation of 30 percent occurs in 2007. 


\section{APPENDIX II: UKRAINE-FUND RELATIONS}

(As of November 30, 2006)

I. Membership Status: Joined 09/03/1992; Article VIII

II. General Resources Account:

Quota

Fund holdings of currency

Reserve position in Fund

III. SDR Department:

Holdings

IV. Outstanding Purchases and Loans:

Extended arrangements
SDR Million

$1,372.00$

1966.78

0.00

SDR Million

0.99

SDR Million

594.78
Quota

100.0

143.35

0.0
Percent Allocation

N/A

Percent Quota

43.35

V. Financial Arrangements:

\begin{tabular}{lrrrr}
\multicolumn{1}{r}{ Type } & $\begin{array}{r}\text { Approval } \\
\text { Date }\end{array}$ & $\begin{array}{r}\text { Expiration } \\
\text { Date }\end{array}$ & $\begin{array}{r}\text { Amount Approved } \\
\text { (SDR million) }\end{array}$ & $\begin{array}{r}\text { Amount Drawn } \\
\text { (SDR Million) }\end{array}$ \\
Stand-by & $03 / 29 / 04$ & $03 / 28 / 05$ & & 411.60 \\
EFF & $09 / 04 / 98$ & $09 / 03 / 02$ & $1,919.95$ & 0.00 \\
Stand-by & $08 / 25 / 97$ & $08 / 24 / 98$ & 398.92 & $1,193.00$ \\
& & & & 181.33
\end{tabular}

VI. Projected Payments to Fund (Expectations Basis) ${ }^{11}$ (SDR million; based on existing use of resources and present holdings of SDRs):

Principal

Charges/Interest

Total

\begin{tabular}{rrrr}
\hline 2006 & 2007 & 2008 & 2009 \\
\hline 42.90 & 278.98 & 215.62 & 57.28 \\
& $\underline{25.49}$ & $\underline{10.94}$ & $\underline{1.68}$ \\
42.90 & 304.46 & 226.55 & 58.96 \\
\hline
\end{tabular}

\footnotetext{
${ }^{11}$ This schedule presents all currently scheduled payments to the IMF, including repayment expectations and repayment obligations. The IMF Executive Board can extend repayment expectations (within predetermined limits) upon request by the debtor country if its external payments position is not strong enough to meet the expectations without undue hardship or risk.
} 
Projected Payments to Fund (Obligation basis) ${ }^{12}$ (SDR million; based on existing use of resources and present holdings of SDRs):

\begin{tabular}{lrrrrr} 
& \multicolumn{5}{c}{ Forthcoming } \\
\cline { 2 - 6 } & 2006 & 2007 & 2008 & 2009 & 2010 \\
\cline { 2 - 6 } Principal & 31.69 & 198.83 & 167.16 & 73.12 & 80.14 \\
Charges/Interest & $\underline{8.61}$ & $\underline{27.51}$ & $\underline{17.00}$ & $\underline{9.55}$ & $\underline{5.88}$ \\
Total & 40.30 & 226.34 & 184.15 & 82.67 & 86.03 \\
\cline { 2 - 6 }
\end{tabular}

\section{Safeguards Assessments:}

The National Bank of Ukraine (NBU) was subject to a safeguards assessment with respect to the Stand-by Arrangement, approved on March 29, 2004. The safeguards assessment was completed on July 14, 2004. The assessment found that the NBU has made progress in recent years to strengthen its safeguards framework, however, further improvements can be made in some areas, notably the financial reporting, legal structure and independence areas. Most of the assessment's recommendations have been implemented. Outstanding issues include (i) the full adoption of International Financial Reporting Standards (IFRS), and (ii) a detailed review of the NBU Law, and other legislation that impinges on the central bank, in order to strengthen the NBU's independence.

\section{Exchange Arrangements:}

In September 1996, the authorities introduced the hryvnia (Hrv) at a conversion rate of karbovanets (Krb) 100,000 to Hrv 1 . The rate was initially informally pegged to the dollar. In September 1997, the peg was replaced by a formal band of Hrv 1.7-Hrv 1.9 per U.S. dollar. The limits of the band were moved on several occasions, most recently on February 9, 1999, to Hrv 3.4-4.6 per U.S. dollar. From March 19, 1999, the exchange rate for the hryvnia was allowed to be determined by the interbank market for foreign exchange. On February 22, 2000, the NBU officially confirmed its intention of allowing the free float of the hryvnia. However, the authorities intervene regularly to limit fluctuations in the exchange rate, so the exchange rate arrangement has been reclassified, effective January 1, 2001, as a conventional pegged arrangement. In April 2005, the hryvnia the appreciated by 43/4 percent to Hrv/US\$ 5.05. On November 30, 2006 the official hryvnia/U.S. dollar rate stood at 5.05.

On September 24, 1996, Ukraine accepted the obligations of Article VIII, Sections 2, 3, and 4 of the Fund's Articles of Agreement, and two remaining restrictions were eliminated in May 1997. A number of new restrictions were introduced in September 1998. The

\footnotetext{
${ }^{12}$ This schedule is not the currently applicable schedule of payments to the IMF. Rather, the schedule presents all payments to the IMF under the illustrative assumption that repayment expectations-except for SRF repayment expectations-would be extended to their respective obligation dates by the IMF Executive Board upon request of the debtor country. SRF repayments are shown on their current expectation dates, unless already converted to an obligation date by the IMF Executive Board.
} 
restrictions on current international transactions introduced in September 1998 were removed in March 1999.

\section{Article IV Consultation:}

Ukraine is on the standard 12-months consultation cycle. The staff report and Ex Post Assessment of Longer-Term Program Engagement (IMF Country Report No. 05/415), the Selected Issues (IMF Country Report No. 05/416), and Statistical Appendix (IMF Country Report No. 05/417) were considered by the Executive Board on November 9, 2005, and published November 28, 2005.

\section{FSAP Participation and ROSCs}

A joint World Bank-International Monetary Fund mission conducted an assessment of Ukraine financial sector as part of the Financial Sector Assessment Program (FSAP) between May 10-24, 2002. An update mission visited Ukraine between February 18-21, 2003, and the Financial Sector Stability Assessment (FSSA) report (IMF Country Report No. 03/340) was considered by the Executive Board on May 14, 2003. The observance of the following standards and codes was assessed: Basel Core Principles for Effective Banking Supervision; Code of Good Practices on Transparency in Monetary and Financial Policies; CPSS Core Principles for Systemically Important Payment Systems; OECD Principles for Corporate Governance; Accounting and Auditing Practices; World Bank's Principles and Guidelines for Effective Insolvency and Creditor Rights System; and AML/CFT Methodology. A further FSAP follow-up mission visited Kyiv between July 25-August 2, 2005 and the review was published in the Selected Issues (IMF Country Report No. 05/416). A Data ROSC Module was conducted in April 3-17, 2002, and was considered by the Executive Board on August 5, 2003 (IMF Country Report No. 03/256). A Fiscal Transparency Module (experimental) was issued in September 1999, and an update in April 2004 (IMF Country Report No. 04/98).

XI. Fund Technical Assistance Missions, 2001-06 (As of November 30, 2006)

\begin{tabular}{|c|c|c|}
\hline Department & Type of Mission & Timing \\
\hline \multirow[t]{7}{*}{ FAD } & Modernizing the State Tax Service & February 7-21, 2006 \\
\hline & Macro-fiscal Analysis & January $10-18,2006$ \\
\hline & Proposals to Reform the Tax System & October $5-18,2005$ \\
\hline & Customs Administration & June $7-21,2005$ \\
\hline & $\begin{array}{l}\text { VAT Refund Management and Selected VAT Administrative } \\
\text { Issues }\end{array}$ & January 30-February 9, 2002 \\
\hline & Treasury and Budget Reforms & April 16-29, 2001 \\
\hline & Treasury Projects & April 6-29, 2001 \\
\hline LEG & $\begin{array}{l}\text { Workshop on Effective Enforcement of Criminal } \\
\text { Justice Measures in Anti-Money Laundering } \\
\text { and Combating the Financing of Terrorism }\end{array}$ & April 2005 \\
\hline \multirow{6}{*}{ MFD } & NBU Internal Audit and Financial Reporting & September 4-12, 2006 \\
\hline & Monetary Policy Communication Strategy & March 6-14, 2006 \\
\hline & Monetary Policy Operations & January 23-February 2, 2006 \\
\hline & Operational Preparations for Exchange Rate Flexibility & December $11-21,2005$ \\
\hline & Action Plan for Transition to Inflation Targeting & October $10-14,2005$ \\
\hline & Foreign Exchange Markets & July $20-28,2005$ \\
\hline
\end{tabular}


Debt Management Strategy (with ICM)

Central Bank Accounting

Implementing Effective AML/CFT Measures

Management of Foreign Exchange Risk in

Transitioning to Greater Exchange Rate Flexibility

Dealing with Problem Banks

Inflation Targeting

Banking Supervision

Banking Supervision, Monetary Framework and

Operations, Government Securities Market

Review of TA Needs

Review of TA Needs and Inspection

Accounting

Internal Audit

Accounting and Internal Audit

STA

Balance of Payments Statistics

Real Sector Statistics

Money and Banking Statistics

SDDS: Assessment

ROSC Data Module Mission

Consumer Price Index

Monetary and Banking Statistics

Consumer Price Index
June 23-July 7, 2005

June 1-15, 2005

May 11-20, 2005

April 18-29, 2005

March 30-April 6, 2005

November 15-19, 2004

October 25-November 12, 2004

April 13-26, 2004

February 9-11, 2004

June 10-12, 2002

October 22-November 2, 2001

October 8-19, 2001

May 3-18, 2001

June 29-July 12, 2005

March 21-April 1, 2005

October 17-23, 2002

June 12-19, 2002

April 3-17, 2002

November 5-16, 2001

May 16-30, 2001

March 12-22, 2001

May 31-June 3, 2005

XII. Fund Resident Representatives and Advisors, 2001-06 (As of November 30, 2006)

\begin{tabular}{|c|c|c|}
\hline Purpose & Representatives/Advisors & Assignment \\
\hline \multicolumn{3}{|l|}{ Resident Representatives } \\
\hline Senior Resident Representative & $\begin{array}{l}\text { Mr. Franks } \\
\text { Mr. Figliuoli } \\
\text { Mr. Ghesquiere }\end{array}$ & $\begin{array}{l}\text { September 2004-present } \\
\text { August 2001-August } 2004 \\
\text { March 1999-August } 2001\end{array}$ \\
\hline Resident Representative & $\begin{array}{l}\text { Mr. Lissovolik } \\
\text { Mr. Orsmond }\end{array}$ & $\begin{array}{l}\text { July 2001-January } 2004 \\
\text { July 1999-July } 2001\end{array}$ \\
\hline \multicolumn{3}{|l|}{ Advisors } \\
\hline $\begin{array}{l}\text { Advisor on Inflation Targeting to the National } \\
\text { Bank of Ukraine }\end{array}$ & Mr. Vavra & $\begin{array}{l}\text { Since January 2006, bi-monthly visits. } \\
\text { November 2004-November } 2005\end{array}$ \\
\hline $\begin{array}{l}\text { Macroeconomic Policy Advisor to the Ministry of } \\
\text { Finance }\end{array}$ & $\begin{array}{l}\text { Mr. Marion } \\
\text { Mr. Robertson } \\
\text { Mr. Marion }\end{array}$ & $\begin{array}{l}\text { April 2006-April } 2007 \\
\text { May 2001-May } 2002 \\
\text { October 1998-April } 2001\end{array}$ \\
\hline $\begin{array}{l}\text { Banking Supervision Advisor at National Bank of } \\
\text { Ukraine }\end{array}$ & $\begin{array}{l}\text { Mr. Livesay } \\
\text { Mr. Lopes }\end{array}$ & $\begin{array}{l}\text { April 2005-October } 2005 \\
\text { March 2001-June } 2002\end{array}$ \\
\hline Treasury Advisor & $\begin{array}{l}\text { Mr. Lepage } \\
\text { Mr. Platais }\end{array}$ & $\begin{array}{l}\text { July 2001-January } 2002 \\
\text { July 1998-June } 2001\end{array}$ \\
\hline Multi-sector Statistics Advisor & Mr. Piché & March 2000-March 2002 \\
\hline Tax Enforcement Advisor & Mr. McDonald & November 1999-April 2001 \\
\hline
\end{tabular}




\section{APPENDIX III: UKRAINE-RELATIONS WITH THE WORLD BANK}

(September 2006)

\section{Country Assistance Strategy}

The World Bank Country Assistance Strategy (CAS) for Ukraine was approved on October 23, 2003. It covers fiscal years 2004-07, and its major focus is to support the "European choice" agenda of Ukraine - including further institutional reform that would lead to a business-friendly environment and a more inclusive and responsive government. It emphasizes the need to work toward Ukraine's European goal both from the top, through reform of institutions and policies, and from the bottom, through strengthening of civil society, which will help to increase public sector accountability. The strategy proposes a US\$2.4 billion Base Case lending program. Allowance is also made for a more ambitious High Case (up to a maximum of US $\$ 3$ billion).

A distinct feature of the Ukraine CAS is its results orientation - the amount and content of financial assistance will depend on the ability of the Government to accomplish the relevant benchmarks.

On July 5, 2005 the Executive Board reviewed the CAS Progress Report which assessed the first two years of the CAS implementation and discussed proposals for the program adjustment. While the overall goals remain broadly unchanged, the strategic priorities outlined in the CAS were adapted to the country's evolving needs.

\section{World Bank Program}

There are 13 operations under implementation in the current project portfolio with total net IBRD commitments of US $\$ 1,163$ million.

The new series of Development Policy Loans were designed to integrate government and donor activities under three broad themes to improve public governance: investment climate; public administration and public finance management; and social inclusion. The first loan in the series-DPL 1 (US\$250 million) was disbursed in FY06.

Among other projects in the public sector are the State Tax Service Modernization Project (US\$40 million), and a Statistical System Modernization Project (US\$32 million).

In the area of rural development, the World Bank supports establishment of the unified registry under Rural Land Titling and Cadastre Development Project (US\$121 million).

The Bank's support for the energy sector has been significant and is expected to increase with a sequence of sector investment loans. The first one, the Hydropower Rehabilitation project (US\$106 million), was approved in June 2005. The project on power transmission (US\$150 million) is under preparation. The Kyiv District Heating Improvement Project (US\$160 million) is under implementation, and the US\$18.29 million Kyiv Public Building Energy Efficiency Project has been successfully completed in June 2005. 
In the infrastructure, the Lviv Water and Wastewater Project (US\$24.25 million) is under implementation. An Urban Infrastructure Project (US\$140 million) is under preparation, and is designed to provide loans to local governments and utilities for priority investments in water, wastewater and solid waste sector. Another project in the pipeline addresses the issues of roads and their safety management (US\$300 million).

In the financial sector, the Bank has recently added two projects to its portfolio: the Access to Financial Services project (US\$150 million) aiming to provide for increased access by the rural population and by municipalities to financial services, and a Second Export Development Project (US\$154 million) to build upon the success of the first project and to promote the Ukrainian economy's export capacity and to strengthen the institutional capacity of Ukreximbank.

The Bank has devoted considerable resources to social sector assistance. The US\$50 million Social Investment Fund Project supports the development of community-based social services for the most vulnerable groups. An Equal Access to Quality Education project (US\$86.6 million), aims to improve the efficiency and quality of education, and to prepare students to compete in a knowledge economy. A project aimed at modernization of the Social Assistance System (US\$99 million) was approved in November 2005.

The Bank is also providing significant non-lending support. Through the People's Voice Program, the World Bank initiated a new generation of programs in Ukraine that focus on the development of civil society. This program is aimed at building integrity at the municipal level through strengthening the voice of citizen groups demanding better governance and services, and by facilitating more responsive public organizations.

The Bank also carries out an extensive program of economic and sector work, including recent studies on the economic and social consequences of energy price increases; labor issues; poverty monitoring; transport; procurement system; and financial accountability. Recently published reports also include a Public Expenditure Review, and a package of policy notes linked to the PAL/DPL program.

World Bank Contact: Sergiy Kulyk, Country Program Coordinator (Tel.:(202) 458-4068). 


\section{APPENDIX IV: UKRAINE-RELATIONS WITH THE EBRD}

(September 2006)

Since Ukraine joined the EBRD in 1992, the Bank has been active in supporting Ukraine's transformation toward a market economy, promoting the business environment, and improving the investment climate for all investors. This has been supported by a range of technical cooperation activities and policy dialogue with the government. The latter has included membership of the Foreign Investment Advisory Council and the EBRD's cochairmanship of the Energy Sector Task Force and the Transport Working Group recently established between EBRD and the Ministry of Transport.

Since the adoption of the 2002 Country Strategy, the main elements of the EBRD's operational strategy have been: encouraging privatization and commercialization of major utilities; encouraging energy efficiency in both the state and private sectors; providing funding through the banks to develop the small and medium business sector (SMEs); and providing working capital to the agricultural sector. This approach was endorsed in a first Program of Co-operation signed in April 2003 by the Government of Ukraine and the EBRD.

The K2R4 project was approved by the EBRD Board and signed in July 2004. The EBRD will lend US\$42 million, with a further US\$83 million from the European Commission (Euratom), to finance post start-up safety and modernization measures at two nuclear reactors. The loan also requires that tariff levels within the nuclear sector should be sufficient to enable the authorities to establish a decommissioning fund, as well as other funds to commence a program of safety upgrades at the other 13 nuclear plants in Ukraine. The respective loan and guarantee agreements were ratified by the Parliament of Ukraine in September 2005.

The EBRD continues to finance small and medium enterprises through local banks without sovereign guarantee including with a US\$88 million sovereign SME II Credit Line. A new US\$200 million framework for SME/MSE lending through local banks was approved in December 2004. During the strategy period, the EBRD also contributed to the progress in developing the Warehouse Receipt Programme (WHR) through the finalization of three projects based on the provision of working capital financing against WHRs. In 2004, the EBRD continued its efforts in establishing a framework for direct lending to municipalities. The Bank began the preparation of the first investment project in the municipal sector without a sovereign guarantee for the city of Dnipropetrovsk.

The current EBRD Country Strategy for Ukraine, approved by the EBRD Board in May 2005, outlined three main areas of operational focus:

- $\quad$ Helping to improve the business climate and the competitiveness of private sector by encouraging and sharing risk with foreign direct investors, promoting syndications, 
enhancing integrity and corporate governance in local private sector projects, and supporting environmental and energy efficiency related projects.

- $\quad$ Strengthening the institutional capacity of the financial sector and increasing the level of finance for micro enterprises and SMEs by supporting consolidation in the banking sector, providing specialized credit lines, working with more banks and starting to work with insurance companies and other non-bank financial institutions.

- $\quad$ Supporting the restructuring and modernization of Ukraine's road, railway, harbor, airport infrastructure, power and oil \& gas sectors by financing sovereign guaranteed projects that help promote transition goals such as greater commercialization or more cost reflective pricing, and promoting new non-sovereign guaranteed structures and providing pre-privatization finance.

The new strategy was underpinned by a second Program of Co-operation for 2005-06 signed in September 2005 by the Government of Ukraine and the EBRD. The agreement identified priority projects including in the transport, energy and municipal infrastructure sectors.

The EBRD's portfolio in Ukraine has increased from 5 projects in 1994 to 64 by the end of August 2006. These amount to a historical net cumulative business volume of EUR2,200 million. About 55 percent of the portfolio (operating assets plus undrawn commitments) was assigned to the private sector and the remaining to the state sector. Operating assets amounted to EUR683.9 million at the end of August 2006.

Outstanding commitments to Ukraine represent about 8 percent of the total of the EBRD's commitments to all its countries of operation as of end-August 2006. There are in addition Technical Cooperation activities in Ukraine which, as of March 2005, included 245 projects with a total value of commitments of almost EUR60 million. These are mainly related to project preparation and implementation.

Projects in the financial sector account for about 23 percent of the EBRD's commitment to Ukraine, with much of this to support the development of small and medium size companies through lending via local commercial banks. The energy sector accounts for a further 16 percent of net commitments. The largest single project in this category is in the power sector; other projects include the development of oil and gas resources, gas transit and energy efficiency. Projects in general industries, including agribusiness, represent about 33 percent of net cumulative commitments, while transport and municipal and environmental infrastructure account for about 22 percent of all commitments.

The EBRD will prepare a new country strategy for Ukraine during the second quarter of 2007. 


\section{APPENDIX V: UKRAINE-STATISTICAL ISSUES}

Economic and financial data provided to the Fund are broadly adequate for surveillance, but there are some important shortcomings. Statistical deficiencies remain for the national accounts and balance of payments, including the absence of proper quarterly price indices for exports and imports. The compilation of accurate data on external assets by sector, and by extension the net international investment position and sectoral balance sheets, suffers from the non-classification of many items.

The data module of the Report on the Observance of Standards and Codes (ROSC) was prepared in 2002, and published on IMF's website on August 19, 2003. The data ROSC recommended strengthening the independence of the State Committee on Statistics (SCS).

On January 10, 2003, Ukraine became the first CIS country to subscribe to the SDDS. Ukraine's first international investment position was compiled by the National Bank of Ukraine (NBU) in 2002. The country's IFS page has been published since July 1996.

While the Fund's technical assistance in statistics has been significantly reduced in recent years, various multilateral and bilateral sources continued to play an important role. A mission by the IMF's Statistics Department (STA) visited in Kyiv in June 2004 to assist in revising the International Transaction Reporting System (ITRS) and assess the quality of current account data.

\section{Real sector statistics}

The 1993 System of National Accounts is the general framework for compiling national accounts and the classifications used are largely in accordance with international standards. The source data are obtained from the extensive survey program of the SCS, supplemented with data from administrative and other sources. The main survey report forms have been revised significantly in recent years to bring them in line with the definitions, scope, and classifications of national accounts data, and the new chart of accounts of enterprises.

Significant improvements have been introduced in the compilation of the quarterly GDP estimates as data are now compiled on a discrete basis and fourth quarter estimates are consistent with the other quarters' estimates. Seasonally adjusted quarterly GDP data are also now compiled, but have been disseminated to only a few selected users. However, quarterly

price indices for exports and imports are still in the development phase, and as yet not suitable for analytical purposes.

A real sector mission by the IMF Statistics Department in March 2005 found that the lack of appropriate price indices hamper production of accurate long-term GDP volume series using the new classification of economic activities adopted since 2001. The authorities also agreed that the methodology covering the informal economy needs to be improved. 
A further improvement of the data collection and production environment is needed, in particular, through greater use of sample surveys, and improving data flow management and processing. To address the shortcomings, it is important to revive the Statistical Council to provide guidance to the SCS on the quality of the statistical series and on strategies for improving data production.

The weights of the consumer price index (CPI) are annually updated; however, their geographical coverage is limited to urban areas. The CPI excludes price changes for owneroccupied housing.

\section{Government finance statistics}

The Ministry of Finance and State Treasury have made considerable progress in the compilation of fiscal data. The Ministry of Finance publishes monthly data on central and regional government operations within 25 days of the reference period. The economic classification of transactions and outstanding debt are consistent with the methodology outlined in A Manual on Government Finance Statistics 1986 (GFSM 1986). From 2002, the functional classification has been consistent with the Government Finance Statistics Manual 2001 (GFSM 2001). All central government transactions and local government revenue transactions are recorded in the Treasury Single Account. Reporting on arrears, both for receipts and payments, should be improved. More importantly, significant delays in reporting on the operations of special social funds, which together represent almost half of general government spending, need to be addressed

The authorities report Government Finance Statistics (GFS) under the GFSM 2001 for publication in the IMF GFS Yearbook. The last year reported is 2005 and data covered the general government and its subsectors.

\section{Monetary and financial statistics}

The data ROSC recommended that the timeliness of the analytical accounts of the central bank be improved using the daily accounting records on monetary operations. Ukraine uses both SDDS flexibility options for monetary data: for timeliness of the analytical accounts of the banking sector and central bank.

The authorities have implemented the Standardized Report Forms (SRF) for reporting monetary data to STA. Data beginning from December 2001 have been converted into the SRF framework and published in the September 2006 issue of IFS Supplement. Updates are available online to IFS users. 


\section{External sector statistics}

The balance of payments is compiled in broad conformity with the fifth edition of the Balance of Payments Manual and reported quarterly to STA. The principal data sources are the ITRS, administrative data sources, and a survey of enterprises.

Following the recommendations of the data ROSC, the authorities have expanded the survey on inter-enterprise arrears to include information relevant for balance of payments purposes. A one-off pilot survey of travelers is to be conducted and it is hoped that this will be the basis for improving the quality of shuttle trade, compensation of employees, and travel estimates. The technical assistance mission of June-July 2005 recommended that reconciliation with partner country data be used to check the coverage of general merchandise and reported that some methodological weaknesses exist in private portfolio and FDI surveys.

Though the cooperation between different government agencies has improved in recent years, problems still exist in coordinating the work of the National Bank of Ukraine, the SCS, and the Ministry of Finance, particularly regarding short-term external debt.

The authorities have made progress in disseminating international reserves data. The release of monthly data, in line with the Fund's reserve template, started in mid-2002. Ukraine also started disseminating external debt data meeting SDDS requirements in September 2004. However, accurate data on external assets suffers from the non-classification of many items, affecting estimates of the net international investment position and sectoral balance sheet information. 


\section{UKRAINE: TABLE OF COMMON INDICATORS REQUIRED FOR SURVEILLANCE}

\begin{tabular}{|c|c|c|c|c|c|c|c|}
\hline & \multirow{2}{*}{$\begin{array}{l}\text { Date of } \\
\text { latest } \\
\text { observation }\end{array}$} & \multirow{2}{*}{$\begin{array}{l}\text { Date } \\
\text { received }\end{array}$} & \multirow{2}{*}{$\begin{array}{c}\text { Frequency } \\
\text { of } \\
\text { data }^{6}\end{array}$} & \multirow{2}{*}{$\begin{array}{l}\text { Frequency } \\
\text { of } \\
\text { reporting }^{6}\end{array}$} & \multirow{2}{*}{$\begin{array}{l}\text { Frequency } \\
\text { of } \\
\text { publication }\end{array}$} & \multicolumn{2}{|c|}{ Memo Items: } \\
\hline & & & & & & $\begin{array}{c}\text { Data Quality - } \\
\text { Methodological soundness }^{7}\end{array}$ & $\begin{array}{l}\text { Data Quality Accuracy } \\
\text { and reliability }\end{array}$ \\
\hline Exchange Rates & $12 / 15 / 06$ & $12 / 15 / 06$ & $\mathrm{D}$ & $\mathrm{D}$ & $\mathrm{D}$ & & \\
\hline $\begin{array}{l}\text { International Reserve Assets and Reserve Liabilities } \\
\text { of the Monetary Authorities } 1\end{array}$ & $11 / 30 / 06$ & $12 / 15 / 06$ & W & W & M & & \\
\hline Reserve/Base Money & $11 / 30 / 06$ & $12 / 4 / / 06$ & $\mathrm{D}$ & $\mathrm{D}$ & M & \multirow[t]{4}{*}{$\mathrm{O}, \mathrm{LO}, \mathrm{O}, \mathrm{O}$} & \multirow[t]{4}{*}{$\mathrm{O}, \mathrm{O}, \mathrm{O}, \mathrm{O}, \mathrm{NA}$} \\
\hline Broad Money & $11 / 30 / 06$ & $12 / 4 / / 06$ & M & M & M & & \\
\hline Central Bank Balance Sheet & $10 / 31 / 06$ & $11 / 20 / 06$ & M & M & M & & \\
\hline Consolidated Balance Sheet of the Banking System & $10 / 31 / 06$ & $11 / 20 / 06$ & M & M & M & & \\
\hline Interest Rates ${ }^{2}$ & $10 / 31 / 06$ & $11 / 20 / 06$ & $\mathrm{D}$ & $\mathrm{D}$ & M & & \\
\hline Consumer Price Index & $11 / 30 / 06$ & $12 / 6 / 06$ & M & M & M & $\mathrm{O}, \mathrm{LO}, \mathrm{O}, \mathrm{O}$ & $\mathrm{O}, \mathrm{O}, \mathrm{LO}, \mathrm{O}, \mathrm{O}$ \\
\hline $\begin{array}{l}\text { Revenue, Expenditure, Balance and Composition of } \\
\text { Financing }{ }^{3} \text { - General Government }\end{array}$ & $10 / 31 / 06$ & $11 / 26 / 06$ & M & M & M & \multirow[t]{2}{*}{$\mathrm{O}, \mathrm{LO}, \mathrm{LO}, \mathrm{O}$} & \multirow[t]{2}{*}{$\mathrm{O}, \mathrm{O}, \mathrm{O}, \mathrm{O}, \mathrm{NA}$} \\
\hline $\begin{array}{l}\text { Revenue, Expenditure, Balance and Composition of } \\
\text { Financing }{ }^{3} \text { - Central Government }\end{array}$ & $10 / 31 / 06$ & $10 / 26 / 06$ & M & M & M & & \\
\hline $\begin{array}{l}\text { Stocks of Central Government and Central } \\
\text { Government-Guaranteed Debt }\end{array}$ & $10 / 31 / 06$ & $11 / 07 / 06$ & M & M & M & & \\
\hline External Current Account Balance & Q3 2006 & Nov. 2006 & Q & Q & Q & \multirow[t]{2}{*}{$\mathrm{O}, \mathrm{LO}, \mathrm{LO}, \mathrm{O}$} & \multirow[t]{2}{*}{$\mathrm{LO}, \mathrm{O}, \mathrm{O}, \mathrm{O}, \mathrm{LO}$} \\
\hline Exports and Imports of Goods and Services & Q3 2006 & Nov. 2006 & Q & Q & Q & & \\
\hline GDP/GNP & Q2 2006 & Oct. 2006 & Q & Q & Q & $\mathrm{O}, \mathrm{LO}, \mathrm{O}, \mathrm{O}$ & $\mathrm{O}, \mathrm{LO}, \mathrm{O}, \mathrm{O}, \mathrm{LO}$ \\
\hline Gross External Debt & Q3 2006 & Nov. 2006 & Q & Q & Q & & \\
\hline
\end{tabular}

${ }^{1}$ Includes reserve assets pledged or otherwise encumbered as well as net derivative positions.

${ }^{2}$ Both market-based and officially-determined, including discount rates, money market rates, rates on treasury bills, notes and bonds.

${ }^{3}$ Foreign, domestic bank, and domestic nonbank financing.

${ }^{4}$ The general government consists of the central government (budgetary funds, extra budgetary funds, and social security funds) and state and local governments.

${ }^{5}$ Including currency and maturity composition.

${ }^{6}$ Daily (D); Weekly (W); Monthly (M); Quarterly (Q); Annually (A); Irregular (I); or Not Available (NA).

${ }^{7}$ Reflects the assessment provided in the data ROSC published in August 2003 and based on the findings of the mission that took place in April 2002 for the dataset corresponding to the variable in each row. The assessment indicates whether international standards concerning (respectively) concepts and definitions, scope, classification/sectorization, and basis for recording are fully observed (O), largely observed (LO), largely not observed (LNO), or not observed (NO).

${ }^{8}$ Same as footnote 7, except referring to international standards concerning (respectively) source data, statistical techniques, assessment and validation of source data, assessment and validation of intermediate data and statistical outputs, and revision studies. 


\section{Statement by the IMF Staff Representative \\ January 12, 2007}

1. Since the issuance of the staff report, more information about 2006 developments has become available, the government agreed with the President to revisit the adopted 2007 budget's wage and pension increases, and the NBU is considering administrative curbs on foreign-exchange lending. This additional information does not change the thrust of the staff appraisal.

2. Preliminary below-the-line data for 2006 indicate that the general government cash deficit may have reached only $1 \frac{1}{4}$ percent of GDP, compared with $23 / 4$ percent of GDP projected in the staff report. If confirmed by the final data, this overperformance likely reflects a combination of stronger-than-projected cash revenue growth and underexecution of spending; information about end-December VAT refund arrears is not yet available.

3. Despite the budget overperformance, the government borrowed an additional US\$600 million externally in December, contributing to international reserves exceeding the staff report's projection by US $\$ 1.1$ billion.

4. End-year CPI inflation was contained at 11.6 percent. The undershoot, relative to staff's forecast of 12.5 percent, reflects legal delays in implementing the envisaged large utility price increases in Kyiv in December.

5. The government and president have agreed to consider additional wage and pension increases in April 2007. The President first vetoed the original 2007 budget law in lateDecember and only signed an almost unchanged version subject to this condition. His proposals would increase average minimum wage growth in 2007 from 15 to 17 percent, and, based on staff estimates, could add $1 / 2$ percent of GDP to recurrent spending.

6. In late-December, the NBU discussed with commercial banks administrative options to curb the rapidly rising foreign-currency-denominated domestic bank lending, particularly to consumers. The NBU's proposals, which are still being developed, could set limits depending on the type of the borrower and the maturity of the foreign-currency loan.

7. The authorities have passed legislation toward WTO accession and expect the WTO to review Ukraine's accession prospects soon. The ban on the sale or transfer of agricultural land has been extended for one more year, and will now expire in 2008.

8. The proposals to further raise wages and pensions underscore staff concerns that the opportunity to reduce recurrent spending is being missed in 2007. Staff continues to view increases in provisions and in the minimum capital-adequacy ratio as the first line of defense against rising indirect credit risk. Administrative curbs on lending would need to be carefully monitored, including to prevent shifts into less well-regulated markets and instruments. 
Public Information Notice (PIN) No. 07/5 FOR IMMEDIATE RELEASE January 22, 2007
International Monetary Fund $70019^{\text {th }}$ Street, NW

Washington, D. C. 20431 USA

\section{IMF Executive Board Concludes 2006 Article IV Consultation with Ukraine}

On January 12, 2007, the Executive Board of the International Monetary Fund (IMF) concluded the Article IV consultation with Ukraine. ${ }^{1}$

\section{Background}

After nose-diving in 2005 , real activity staged a surprise rebound in 2006 . Fiscal policy in 2005-06 reshuffled resources from higher-saving businesses (mainly by raising tax collections) to lower-saving households (mainly by raising public pensions and wages), touching off a consumption boom, which has been reinforced by rapid credit expansion. In 2005, this boom helped to offset the drag on the economy from marked real currency appreciation, weaker steel exports owing to intensified third-country competition, higher business-tax collections, and post-Orange-Revolution reforms, which clamped down on tax loopholes, smuggling, and corruption. In 2006, robust consumption has been matched by stronger export markets, including resurging steel prices, and more buoyant investment, as reforms began to bear fruit in attracting higher foreign direct investment (FDI).

Inflation moderated through most of 2006, but has recently climbed back into double digits, boosted by energy-price pass-through. Notwithstanding booming consumption, high CPI inflation started to moderate in mid-2005, reflecting slowing real activity, low import price inflation, and a host of one-off factors, including cuts in import tariffs and temporary Russian import bans on Ukrainian meat and dairy products. However, as pass-through of energy import price hikes accelerated in late-2006, inflation surged back

\footnotetext{
${ }^{1}$ Under Article IV of the IMF's Articles of Agreement, the IMF holds bilateral discussions with members, usually every year. A staff team visits the country, collects economic and financial information, and discusses with officials the country's economic developments and policies. On return to headquarters, the staff prepares a report, which forms the basis for discussion by the Executive Board. At the conclusion of the discussion, the Managing Director, as Chairman of the Board, summarizes the views of Executive Directors, and this summary is transmitted to the country's authorities.
} 
into the double digit range. Domestic price pressures, as measured by the GDP deflator and labor costs, have remained significant throughout this period.

Ukraine's steep terms-of-trade gains came to an abrupt halt in 2006. Ukraine's cumulative terms-of-trade improvement during 2003-05 amounted to some 20 percent, as skyrocketing prices for steel—Ukraine's main export-offset sharply higher oil prices. However, amid a dispute with Russia in early-2006, the price of imported natural gas was hiked by 65 percent. As one of the most inefficient users of energy among transition economies and as a heavy net energy importer, this price hike was enough to offset the impact of still higher average metals prices and a higher fee for transit of gas. As a result, the terms of trade deteriorated by about 1 percent.

The current account has switched from large surpluses into deficit, but capital flows have picked up and international reserves have reached healthy levels. With domestic demand booming, export volumes slumping, and the terms of trade reverting, the current account shifted from a surplus of 101/2 percent of GDP in 2004 to a likely deficit of about 1 percent of GDP in 2006. At the same time, capital inflows, FDI in particular, have been buoyant, reflecting improved perceptions of Ukraine as an investment location. As a result, foreign exchange reserves have more than doubled to about $4 \frac{1}{2}$ months of imports and are projected to exceed the level of short-term external debt at end-2006.

The authorities have proven adept at hitting low fiscal deficit targets, and explicit public debt has plunged. In 2005, despite a slowing economy and no financing constraints (privatization receipts reached 5 percent of GDP), the tight general government cash deficit target of $2 \frac{1}{2}$ percent of GDP was met. Preliminary data for 2006 indicate that the general government cash deficit may have reached only $1 \frac{1}{4}$ percent of GDP, compared the 2006 deficit target of about 3 percent of GDP, reflecting robust Value Added Tax collections and expenditure restraint. A combination of strong nominal growth and low deficits will reduce explicit public debt (including government-guaranteed debt) to a projected 17 percent of GDP by end-2006, down from over 60 percent in 1999. However, contingent liabilities remain at a still high 30 percent of GDP, largely reflecting claims from the so-called lost savings deposits from the early 1990s hyperinflation.

Reflecting a redistributionist shift in fiscal policy, recurrent spending and tax collections from businesses have both been ratcheted upward. In 2005, average public wages and pensions were raised by over 50 percent (against an inflation target of just under 10 percent). As a result, pension spending commitments soared from 12 percent of GDP in 2004 to about 17 percent in 2005. To finance this recurrent-spending boom, while reducing the fiscal deficit, the government curtailed capital spending by some $13 / 4$ percent of GDP and raised tax collections by some 6 percent of GDP, the latter especially through an across-the-board cancellation of tax breaks for the free economic zones and administrative improvements. The 2006 budget largely preserved the thrust of these policies. 
Monetary conditions have continued to adjust passively to the requirements of the exchange rate peg. Although the National Bank of Ukraine (NBU) has allowed the interbank exchange rate to fluctuate within a narrow band of Hrv/US\$5.00-5.06, the exchange rate regime has remained a de facto peg. In this setting, base money growth has been mostly driven by foreign-exchange interventions and changes in government deposits at the NBU. During most of 2006, the NBU's reaction function implied an automatic tightening of the monetary stance, partly softened by the NBU lowering reserve requirements and its main refinancing rate. More recently, however, monetary conditions have loosened again, reflecting a pickup in foreign reserve accumulation and drawdown of government deposits.

A long-lasting credit boom has increased the balance-sheet vulnerabilities of banks and their borrowers. Real credit growth has averaged about 40 percent since 2001. The corporate sector's debt (two thirds of which is denominated in foreign currency) now exceeds 50 percent of GDP. Household sector debt, mostly in foreign exchange, has also surged over the past 18 months, partly driven by banks' fierce competition for market share. The boom has created substantial credit risk, in particular indirect foreigncurrency risk, since most borrowers are unhedged. It has also raised banks' foreign exchange liquidity risk as banks have increasingly relied on foreign funding, much of which is at short maturities. While an influx of foreign banks since 2004 has improved credit-risk management practices in some parts of the banking system, recent financial soundness indicators, particularly declining capital-adequacy ratios, suggest that the sector as a whole remains vulnerable.

Financial markets remain underdeveloped, reflecting history, deficient policies, and lagging legal frameworks. The government securities market remains illiquid and shallow with no significant primary issuances between August 2005 and October 2006. Equities markets also remain illiquid due to the delay in passing a joint-stock company law that would protect minority shareholders. Domestic corporate bond issuance has been more buoyant, but starting from a low level. A key tax barrier to financial sector development, the foreign exchange transactions tax, has been reduced marginally, but remains in place. 


\section{Executive Board Assessment}

Executive Directors noted that Ukraine's economy has proven resilient over the last year in the face of higher energy prices and domestic political uncertainties. Directors also noted that the economy had become better balanced externally, with the current account now near balance after several years of large surpluses. However, They also observed that rising prices for imported energy have rekindled short-term macroeconomic tensions, while uncertainties about future steel export prices and capital flows loom large.

Directors stressed that Ukraine also needs to address three longer-standing challenges. First, while welcoming recent progress in adopting more market-friendly institutions, they noted that structural reforms still lag considerably. Second, Directors thought that the present monetary framework could face increasing difficulties in achieving internal and external balance given Ukraine's volatile macroeconomic fundamentals. And third, Directors expressed concern that the sustained credit boom and heavy private-sector external borrowing had created balance-sheet vulnerabilities, raising risks to the banking sector.

Turning to policies, Directors considered that a gradual move toward greater exchange rate flexibility would facilitate external adjustment and help improve control of inflation. A more flexible exchange rate could also help stem financial dollarization while providing incentives to develop markets to hedge foreign-exchange risks. Several Directors cautioned, however, that the pace of transition needs to be managed carefully and be kept aligned with the development of supporting conditions. Directors therefore welcomed the preparatory steps taken by the NBU toward introducing inflation targeting, and encouraged the authorities to move forward with the transition.

Directors stressed the importance of stepping up the implementation of policies that will support increased exchange rate flexibility. These should include measures to develop the foreign-exchange market, including by eliminating the foreign-exchange transactions tax, and domestic securities markets, particularly by adopting a government financing strategy that relies more on domestic debt issuance. Moreover, an appropriately restrained incomes policy would reduce the pressure for large nominal exchange rate movements in the face of a highly uncertain external environment.

Directors underscored the criticality of more proactive regulation and supervision of the banking sector. They therefore welcomed the NBU's recent steps to improve regulatory and supervisory safeguards. Most Directors considered that capital-adequacy should be strengthened until banks' risk management practices improve and, in this regard, noted that consideration should be given to increasing the capital-adequacy ratio from 10 to 12 percent. In this context, Directors welcomed the envisaged Financial Sector Assessment Program update in 2007 as timely. 
Directors viewed the authorities' fiscal framework as broadly appropriate. The authorities' intention to target a general government deficit close to $2 \frac{1}{2}$ percent of GDP would keep explicit debt low, providing a prudent cushion given significant contingent fiscal liabilities. At the same time, plans to reverse the recent surge in recurrent spending over the medium term would create fiscal space for tax cuts and public investment.

Directors urged the authorities to implement policies consistent with this fiscal framework. In particular, they emphasized to do more to restrain recurrent spending in the 2007 budget. Increases in sectoral subsidies and the reopening of tax breaks in the free economic zones should be avoided, as they could encourage rent seeking. Directors also stressed that opening significant fiscal space would require tackling large public pension fund imbalances, although pension reforms were also imperative for demographic reasons.

Directors commended the authorities for passing through recent energy import price hikes to domestic users and urged them to continue pass-through in 2007 and beyond. This would help avoid rising quasi-fiscal deficits and provide incentives to improve Ukraine's very low energy efficiency.

Directors stressed that raising growth in Ukraine required improvements in the country's difficult investment climate. They particularly noted the pressing need to adopt legislation to strengthen investor rights, clarify inconsistencies between the economic and civil codes, reactivate a transparent and fair privatization process, and reform the energy sector.

Directors welcomed the passing of legislation towards WTO accession in 2007, but urged reversing recent retrograde actions against exporters, particularly the introduction of restrictions on grain exports.

While noting that official statistics were broadly adequate for surveillance, Directors saw a need to improve data on trade prices, the state-owned enterprise sector, and sectoral financial flows and stocks.

Public Information Notices (PINs) form part of the IMF's efforts to promote transparency of the IMF's views and analysis of economic developments and policies. With the consent of the country (or countries) concerned, PINs are issued after Executive Board discussions of Article IV consultations with member countries, of its surveillance of developments at the regional level, of post-program monitoring, and of ex post assessments of member countries with longer-term program engagements. PINs are also issued after Executive Board discussions of general policy matters, unless otherwise decided by the Executive Board in a particular case. 
Ukraine: Selected Economic and Social Indicators, 2003-07

\begin{tabular}{|c|c|c|c|c|c|c|}
\hline \multirow{3}{*}{ Real economy (percent change unless indicated otherwise) } & \multirow[t]{2}{*}{2003} & \multirow[t]{2}{*}{2004} & \multirow[t]{2}{*}{2005} & \multirow{2}{*}{$\begin{array}{l}2006 \\
\text { Proj. }\end{array}$} & \multicolumn{2}{|c|}{2007} \\
\hline & & & & & $\begin{array}{l}\text { Authorities' } \\
\text { Policies 1/ }\end{array}$ & $\begin{array}{r}\text { Recommended } \\
\text { Policies 2/ }\end{array}$ \\
\hline & & & & & & \\
\hline Nominal GDP (billions of hryvnias) & 267.3 & 345.1 & 424.7 & 505.4 & 565.4 & 573.7 \\
\hline Real GDP & 9.6 & 12.1 & 2.6 & 6.0 & 4.3 & 4.5 \\
\hline Consumer prices (period average) & 5.2 & 9.0 & 13.5 & 9.1 & 12.9 & 13.6 \\
\hline Consumer prices (end of period) & 8.2 & 12.3 & 10.3 & 12.5 & 8.2 & 10.6 \\
\hline Consumer prices excluding energy (end of period) & 7.7 & 11.2 & 9.4 & 8.3 & 8.3 & 8.3 \\
\hline Nominal monthly wages (average) & 23.0 & 27.7 & 36.5 & 23.3 & 14.9 & 14.3 \\
\hline Real monthly wages (average) & 16.9 & 17.1 & 20.3 & 13.0 & 1.8 & 0.6 \\
\hline \multicolumn{7}{|l|}{ Public finance (percent of GDP) } \\
\hline Cash balance & -0.9 & -4.4 & -2.4 & -2.4 & -4.1 & -2.5 \\
\hline Revenue 3/ & 35.9 & 35.0 & 41.3 & 43.0 & 43.2 & 42.9 \\
\hline Expenditure (cash basis) & 36.8 & 39.5 & 43.6 & 45.4 & 47.3 & 45.3 \\
\hline Primary balance (cash basis) & 0.1 & -3.5 & -1.6 & -1.7 & -3.2 & -1.5 \\
\hline Commitments balance 4/ & -1.2 & -4.1 & -1.9 & -2.7 & -4.0 & -2.4 \\
\hline Privatization proceeds & 1.1 & 3.1 & 5.1 & 0.1 & 2.0 & 1.9 \\
\hline Net domestic financing & -1.2 & -0.1 & -3.4 & 1.7 & 0.0 & 0.4 \\
\hline Net external financing $3 /$ & 1.0 & 1.4 & 0.6 & 0.6 & 0.9 & 0.1 \\
\hline Public debt $5 /$ & 30.6 & 25.5 & 19.4 & 16.8 & 16.2 & 14.6 \\
\hline Of which: external debt & 21.6 & 19.2 & 14.7 & 12.2 & 11.3 & 10.6 \\
\hline \multicolumn{7}{|l|}{ Money and credit (end of period, percent change) } \\
\hline Base money & 30.1 & 34.1 & 53.9 & 18.8 & 17.2 & 12.0 \\
\hline Broad money & 46.5 & 32.3 & 54.4 & 33.7 & 30.5 & 22.1 \\
\hline Credit to the economy & 63.4 & 31.2 & 61.5 & 64.0 & 35.3 & 24.3 \\
\hline Velocity $6 /$ & 2.81 & 2.75 & 2.19 & 1.95 & 1.67 & 1.81 \\
\hline \multicolumn{7}{|l|}{ Balance of payments (percent of GDP) } \\
\hline Current account balance & 5.8 & 10.5 & 3.1 & -1.0 & -3.9 & -3.1 \\
\hline Foreign direct investment & 2.8 & 2.7 & 9.0 & 3.8 & 4.9 & 4.9 \\
\hline Gross reserves (end of period, billions of U.S. dollars) & 6.9 & 9.5 & 19.4 & 21.1 & 23.5 & 24.1 \\
\hline In months of next year's imports of goods and services & 2.4 & 2.7 & 4.4 & 4.2 & 4.2 & 4.3 \\
\hline Debt service (in percent of exports of goods and services) $5 /$ & 6.2 & 4.6 & 4.9 & 5.1 & 4.6 & 4.5 \\
\hline Goods exports (annual volume change in percent) & 14.1 & 18.2 & -5.4 & 6.7 & 7.9 & 10.2 \\
\hline Goods imports (annual volume change in percent) & 30.3 & 13.8 & 14.6 & 11.2 & 6.9 & 6.9 \\
\hline Goods terms of trade (percent change) & 8.7 & 9.6 & 6.1 & -3.5 & -8.8 & -8.8 \\
\hline Goods and services terms of trade (percent change) & 7.3 & 7.8 & 4.9 & -1.1 & -5.9 & -5.8 \\
\hline \multicolumn{7}{|l|}{ Exchange rate } \\
\hline Exchange rate regime & \multicolumn{3}{|c|}{ de facto peg } & \multicolumn{2}{|c|}{ de facto peg } & managed float \\
\hline Hryvnia per U.S. dollar, end of period & 5.33 & 5.31 & 5.05 & 5.05 & $\ldots$ & $\ldots$ \\
\hline Hryvnia per U.S. dollar, period average & 5.33 & 5.32 & 5.12 & 5.05 & $\ldots$ & $\ldots$ \\
\hline Real effective rate (percent change) $7 /$ & -5.7 & 2.7 & 17.0 & 8.0 & $\ldots$ & $\ldots$ \\
\hline
\end{tabular}

Social indicators

Per capita GDP: US\$1,747 (2005); Poverty (percent of population): 31.7 (2001; national headcount index);

Life expectancy at birth: 68.2 years (2002); Infant mortality (per 1,000): 16.0 (2002); Gross primary enrollment (percent net): 84 (2002)

Sources: Ukrainian authorities; and IMF staff estimates and projections.

1/ Authorities' policies under the baseline external outlook. Policies include: (i) a fixed exchange rate; (ii) full pass-through of rising energy import prices to industry, but zero pass-through to consumers; (iii) a fiscal deficit target of 2.9 percent of GDP; and (iv) growth in the minimum wage of 12.5 percent.

2/ Staff recommended policies under baseline external outlook. These include (i) increased flexibility in the hryvnia/U.S. dollar exchange rate; (ii) full pass-through of rising energy import prices to both industry and consumers; (iii) a fiscal-deficit target of 2.5 percent; (iv) end-period minimum wage growth of 8 percent; and (iv) a monetary policy that aims to reduce core inflation.

3/ From 2003 onward, based on an accounting treatment that excludes offset-based amortization to Russia, which decreases revenues and increases net external financing (and the budget deficit) by 0.2 percent of GDP relative to previous years.

4/ Cash balance adjusted for the net accumulation of expenditure and VAT refund arrears, as well as for non-cash property income.

5/ Government and government-guaranteed debt and arrears, plus NBU debt. Excludes debt by state-owned enterprises.

6/ Annual GDP divided by end-period broad money (M3).

7/ Period averages; (+) represents real appreciation; based on GDP deflator and INS trade weights (1999-2001). 